Journal of Applied Finance \& Banking, Vol. 11, No. 5, 2021, 121-183

ISSN: $1792-6580$ (print version), 1792-6599 (online)

https://doi.org/10.47260/jafb/1156

Scientific Press International Limited

\title{
Monetary Policy Rules vs Discretion: Social Cost and Benefits
}

\author{
Dr. Ioannis N. Kallianiotis ${ }^{1}$

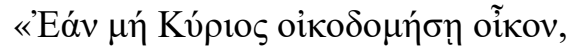

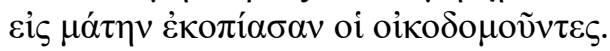

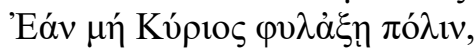

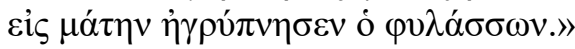 \\ $\Psi \alpha \lambda \mu \operatorname{ó}_{\varsigma} \rho \kappa \varsigma^{\prime} 1-2$
}

\begin{abstract}
In this article it is discussed the new monetary policy, the new instruments (monetary policy tools) that the Fed introduced after 2008 and 2020, the different monetary policy rules, and the social cost and benefits of this policy is measured. The first major Fed's changes were on 12/20/2008 by altering the fed funds market in a number of different ways: (1) Zero fed funds rate. (2) The Fed started paying interest on reserves held by the bank or on behalf of depository institutions at Reserve Banks, subject to regulations of the Board of Governors, effective October 1, 2011 and interest on the overnight reverse repurchase agreement in 2014. (3) The close to zero deposit rates. (4) The Fed abolished the required reserves by making them since March 26, 2020 zero. The social cost is very high with these "innovated" policies. This zero federal funds target rate monetary policy is against depositors (bail in cost) and taxpayers (bail out cost); it is an unfair public policy and an antisocial monetary policy; and at the same time it is a risky one because it has created enormous bubbles in the stock market and a creeping high inflation. The different monetary policy rules reveal the unjustifiable low policy target rates. The latest monetary policy combined with the loss of self-sufficiency, the outsourcing, the unfair international trade, the recent peculiar coronavirus pandemic, and the current divisions inside the country are generating many challenges and risks for the future, which will cause the social cost to exceed the social benefits.
\end{abstract}

${ }^{1}$ Economics/Finance Department. The Arthur J. Kania School of Management.

University of Scranton. Scranton, PA, U.S.

Article Info: Received: August 15, 2021. Revised: August. 29, 2021.

Published online: September 2, 2021. 
JEL classification numbers: E52, E58, E4, E44, E23, D6.

Keywords: Monetary Policy, Central Banks and Their Policies, Money and Interest Rates, Financial Markets and the Macro-economy, Production, Social Welfare.

\section{Introduction}

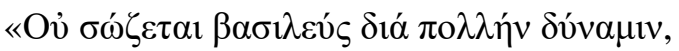

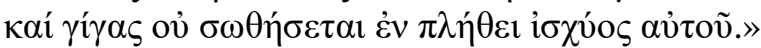
$\Psi \alpha \lambda \mu$ ó 32,16

Central banks, the most powerful establishments, as all the institutions and international organizations, have very curious history, eccentric march, and mysticism in their hidden "social" objectives. Monetary policy has passed many different phases, revisions, and "improvements" since monetary authority's (Fed's) creation in $1913,{ }^{2}$ and affects drastically depositors, borrowers, and taxpayers. This Central Bank intended to serve as a formal "lender of last resort" to banks in times of liquidity crises and panics, when depositors try to withdraw their money faster than a bank could pay it out, as it happened many times in $19^{\text {th }}$ century. ${ }^{3}$ This Act brought all banks in the United States under the authority of the Federal Reserve (a quasi-governmental entity, actually a private bank) by creating the twelve (12) regional Federal Reserve Banks, ${ }^{4}$ which are supervised by the Federal Reserve Board. ${ }^{5}$ Of course, historically, the roles and functions of the Fed are given by the Federal Reserve Act $^{6}$ and they are: (1) Market (Financial Market) Stabilization, (2) Control of Money Supply, (3) Lender of Last Resort, (4) Supervisor of the Banking System, and (5) Maintaining and Improving the Payment Mechanism. ${ }^{7}$

${ }^{2}$ See, Kallianiotis (2017a). Also, see, https://en.wikipedia.org/wiki/History_of monetary_policy in the United_States . Further, https://www.federalreserveeducation.org/about-the-fed/history . Furthermore, https://www.federalreserve.gov/monetarypolicy/historical-approaches-to-monetary-policy.htm . In addition, https://www.clevelandfed.org/en/newsroom-and-events/speeches/sp-20140327-thefederal-reserve-policy-approaches-then-and-now.aspx . And even more, https://www.frbsf.org/education/teacher-resources/what-is-the-fed/history/

${ }_{3}$ Between 1863 and 1913, eight banking panics occurred in the money center of Manhattan. The panics in 1884, 1890, 1899, 1901, and 1908 were confined to New York and nearby cities and states. The panics in 1873, 1893, and 1907 spread throughout the nation. Regional panics also struck the mid-western states of Illinois, Minnesota, and Wisconsin in 1896; the mid-Atlantic states of Pennsylvania and Maryland in 1903; and Chicago in 1905. These crises disrupted or threatened to disrupt the national banking and payments system. The Panic of 1907, was the shock that spurred financial and political leaders to consider reforming the monetary system and eventually establish the Federal Reserve. See, "Banking Panics of the Gilded Age", https://www.federalreservehistory.org/essays/banking-panics-of-the-gilded-age

${ }^{4}$ See, The Federal Reserve Banks. https://en.wikipedia.org/wiki/Federal_Reserve_Bank

${ }^{5}$ See, The Federal Reserve Board. https://en.wikipedia.org/wiki/Federal_Reserve_Board_of_Governors

6 See, "Federal Reserve Act", https://www.federalreserve.gov/aboutthefed/fract.htm

7 See, Kallianiotis (2017a). 
This monetary authority of the U.S. has adopted a public policy, which is called the monetary policy. ${ }^{8}$ It controls either the interest rate (federal funds rate, $i_{F F}$ ) payable for overnight or very short-term borrowing (borrowing by banks from each other to meet their short-term needs, the federal funds market) or the money supply ( $M^{s}$, borrowing or non-borrowing reserves). These intermediate targets $\left(i_{F F}\right.$ and $M^{s}$ ) are used often as an attempt to reduce inflation or to contribute to maximum employment (since 1977), called the dual mandate ${ }^{9}$ or to control the interest rate, to ensure price stability and general trust of the value and stability of the nation's currency. Also, to generate a stable real economic growth (to smooth the business cycle and offset economic shocks), a moderate long-term interest rate, an equilibrium in the current account, and a financial stability for our market.

The central bank, before October 1979, was targeting federal funds rate $\left(\bar{i}_{F F}\right)$.

After that date, it started targeting the money supply directly (non-borrowed reserves, $\left.R^{*}\right)$. Later, after 1989 , Fed targets the federal funds rate $\left(\bar{i}_{F F}\right)$ and with this intermediate target rate, it influences all interest rates by expanding or contracting the monetary base $(M B)$, which consists of currency $(C)$ in circulation and banks' reserves $(R)$ at the central bank, which affect the money supply $\left(M^{s}\right)$. The primary tools of monetary policy that the central bank was using to affect the monetary base were open market operations (OMO), which are sales (OMS) and purchases (OMP) of government debt and later, mortgage-back securities, too, in the open market, or by changing the reserve requirements $\left(R_{R}\right)$. Also, there are used the discount rate $\left(i_{D R}\right)$, reserve requirements ratio $\left(r_{R}\right)$, and margin requirements $\left(r_{m}\right)$. If the central bank wishes to lower interest rates, it purchases government debt, thereby increasing the amount of cash in circulation or crediting banks' reserves; the $R_{1}^{s}$ shifts to the right at $R_{2}^{s}$ and $i_{F F_{1}}$ falls to $i_{F F_{2}}$, Figure 1.

\footnotetext{
${ }^{8}$ See, Monetary Policy. https://en.wikipedia.org/wiki/Monetary_policy

9 See, "The Federal Reserve's Dual Mandate". https://www.chicagofed.org/research/dualmandate/dual-mandate
} 


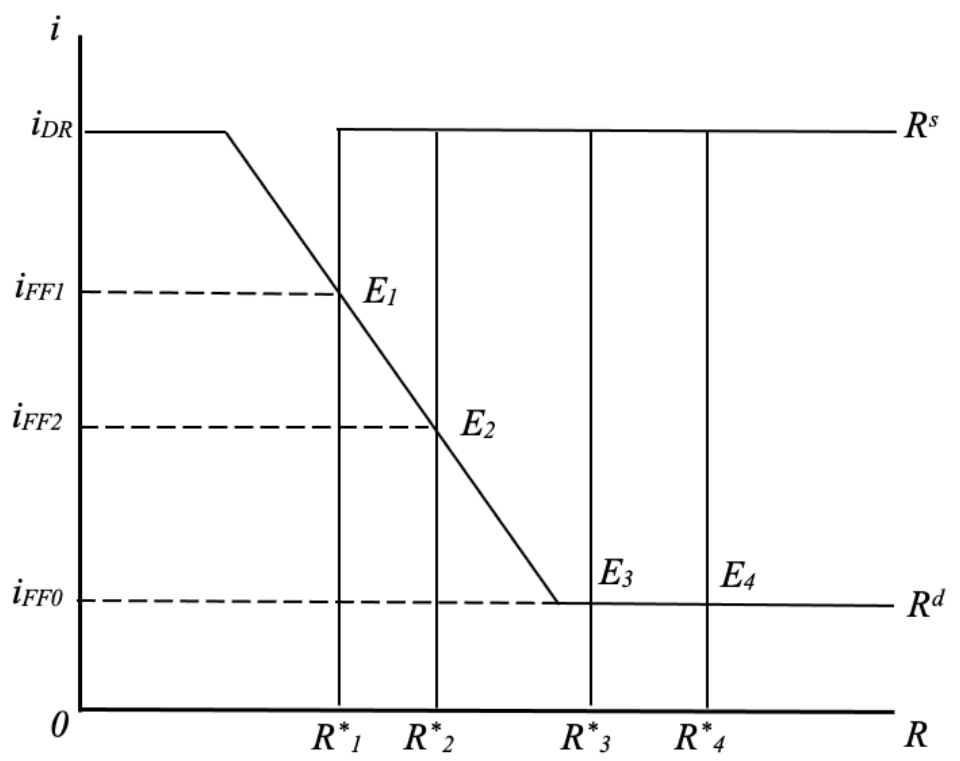

\section{Figure 1: Monetary Policy with Limited Reserves and Federal Funds}

Note: $i=$ interest rates, $i_{F F}=$ federal funds rate, $i_{D R}=$ discount rate, $R=$ reserves, $R^{d}=$ demand for reserves, $R^{s}=$ supply of reserves, $E=$ equilibrium $\left(R^{s}=R^{d}\right)$.

In the 1990s, central banks (Fed) began adopting formally, public inflation targets with the goal of making the outcomes, if not the process, of monetary policy more transparent. In other words, a central bank must have an inflation target of $2 \%$ for a given year. The Fed's target is based on the annual change in the overall, or "headline," $P C E$ price index (Personal Consumption Expenditures inflation). Although the FOMC did not explicitly name an inflation target until 2012. St. Louis Fed President James Bullard has argued that the U.S. had "an implicit inflation target of 2 percent after $1995 " .{ }^{10}$ In his presentation, Bullard noted that $2 \%$ became an international standard in the inflation targeting era that began in the 1990s. ${ }^{11} \mathrm{In}$ the 2016 version of the Statement on Longer-Run Goals and Monetary Policy Strategy, ${ }^{12}$ the $F O M C$ clarified that its inflation target is symmetric (in other

\footnotetext{
10 See, Bullard (2018a). presentation from Sept. 12, 2018.

11 See, Engemann (2019).

12 "The Federal Open Market Committee (FOMC) is firmly committed to fulfilling its statutory mandate from the Congress of promoting maximum employment, stable prices, and moderate longterm interest rates. The Committee seeks to explain its monetary policy decisions to the public as clearly as possible. Such clarity facilitates well-informed decision-making by households and businesses, reduces economic and financial uncertainty, increases the effectiveness of monetary policy, and enhances transparency and accountability, which are essential in a democratic society." See, "Statement on Longer-Run Goals and Monetary Policy Strategy Adopted effective January 24, 2012; as amended effective January 26, 2016". https://www.federalreserve.gov/monetarypolicy/files/FOMC_LongerRunGoals 20160126.pdf
} 
words, it is not a floor or a ceiling). The FOMC added: "The Committee would be concerned if inflation were running persistently above or below this objective." In August 2020, after undershooting its $2 \%$ inflation target for years, ${ }^{13}$ the Fed announced it would be allowing inflation to temporarily rise higher, in order to target an average of $2 \%$ over the longer term. It is still unclear if this change will make much practical difference in monetary policy anytime soon. But, a zero interest rate and an enormous money supply how can keep inflation on $2 \%$ target? Other major Fed's changes took place on December 20, 2008, which altered the fed funds market in a number of astonishing ways: zero fed funds rate $\left(i_{F F}=0.00 \%\right),{ }^{14}$ including the types of financial institutions that were trading, the rates at which they were borrowing and lending, and the new tools introduced by the FOMC that could effectively influence these market rates. Last year on March 20, 2020, due to the suspicious Chinese coronavirus pandemic, which has been exploited so much by the liberal politicians, Fed went back to zero interest rate. ${ }^{15}$ Because banks were overflowed with reserves, their desire to borrow effectively vanished, and bank -tobank lending largely disappeared. ${ }^{16}$

13 But, in Summer 2020, the true unofficial inflation was about $10 \%$ p.a. and in December 2020, it fell to $8 \%$. In June 2021, had risen to $13 \%$. See, SGS,

http://www.shadowstats.com/alternate_data/inflation-charts. See, also,

https://ycharts.com/indicators/us_inflation_rate

${ }_{14}$ See, "Federal Funds Target Range", https://fred.stlouisfed.org/series/DFEDTARU

15 The Federal Reserve left the target range for its federal funds rate unchanged at $0 \%-0.25 \%$, as expected. Policymakers reiterated they are committed to using a full range of tools to support the U.S. economy in this challenging time. The so-called dot plot of funds rate projections showed rates are expected to remain at current levels through 2022 (another "expert", Bill Gates, said that the pandemic will be over in 2022). (Sic). The CDC is talking about a new Delta variant in Fall 2021, which is already here, to force vaccination and political control on all people and on children. The Fed also said it will continue to increase its bond holdings, targeting Treasury purchases at $\$ 80$ billion a month and mortgage-backed securities at $\$ 40$ billion. https://tradingeconomics.com/unitedstates/interest-rate . Further, the official unemployment with October 2020 was $6.9 \%$, with February 2021, it was 6.2\%, and with June 2021, it was 5.9\%. The SGS gives the following values: May 2020 ShadowStats Alternate Unemployment was 34.0\%, 36.5\% net of BLS errors (Flash Nos. 1435 and 1439). In November 2020, the unemployment was $26.3 \%$ and in June 2021, it was $u=25.8 \%$.

http://www.shadowstats.com/alternate data/unemployment-charts.

The Consumer inflation- Official was $0.55 \%$ with October 2020 and $1.7 \%$ with February 2021 vs ShadowStats (1080-Based) Alternative, which was 8\% with May 2020 and the same it was in October 2020, 8\%; but, in February 2021, it was 9\% and in June it became 13\%.

http://www.shadowstats.com/alternate_data/inflation-charts. See also, US Unemployment. https://www.deptofnumbers.com/unemployment/us/\#: :text=US\%20Unemployed.\%20The\%20nu mber\%20of\%20people\%20unemployed\%20in,of\%20unemployed\%20has\%20now\%20grown $\% 20$ again $\% 20 \mathrm{by} \% 200$. Why would anyone trust officials again and especially the current liberalglobalists, which their life is a big lie?

${ }_{16}$ See, Key Features of the Federal Funds Market, Liberty Street Economics, https://libertystreeteconomics.newyorkfed.org/2018/07/size-is-not-all-distribution-of-bankreserves-and-fed-funds-dynamics/comments/. 
However, once the Fed started paying interest on reserves ${ }^{17}$ to some (but not all) financial institutions, a new lending opportunity emerged. This Fed's "innovation" (paying interest of reserves, a bail out cost for the taxpayers) has kept the deposit rate closed to zero $\left(i_{D}=0.05 \%\right)$ for twelve years ${ }^{18}$ and because we are living in a free market economic system, banks charge an unethical (usurious) interest rate on credit cards up to $39.99 \%$; a spread between deposit rate and credit card rate of $39.94 \%$.

The latest "innovation" of the Fed came last year. It considered the required reserves as non-necessary monetary instrument and made them since March 26, 2020 zero $\left(R_{R}=0\right)$; the federal funds rate zero $\left(i_{F F}=0.00 \%\right),{ }^{19}$ and the effective federal funds rate with May 2020 was $i_{F F}^{e f f}=0.05 \%$; the discount rate was $\left(i_{D R}=0.25 \%\right) .{ }^{20}$ This means that it abandoned the reserve requirement ratio $\left(r_{R}=0.00 \%\right)$, as a monetary policy tool. ${ }^{21}$ This is a new major bank deregulation, which is very risky for the financial institutions and the economy, due to enormous liquidity. The Fed has substituted the required reserves with the excess reserves by supplying them in trillions of dollars, $R_{E}=\$ 3.218$ trillion (May 2020). The total reserves were $\$ 3.035$ trillion with November 2020 and reached $\$ 3.872$ trillion in June 22, 2021. ${ }^{22}$ The interest on reserves that Fed is paying to the banks is now (June 18, 2021),

17 The Financial Services Regulatory Relief Act of 2006 authorized the Federal Reserve Banks to pay interest on balances held by or on behalf of depository institutions at Reserve Banks, subject to regulations of the Board of Governors, effective October 1, 2011. The effective date of this authority was advanced to October 1, 2008, by the Emergency Economic Stabilization Act of 2008.

$18 \mathrm{See}$, https://www.valuepenguin.com/banking/average-bank-interest-rates

${ }^{19}$ Global and U.S. bank stocks fell on Thursday (6/11/2020); DJIA lost $1,861.82$ points (-6.9\%) to $25,128.17$, a day after Fed officials indicated they had no plans to raise interest rates over the next two years. Shares of JPMorgan Chase JPM -8.34\% \& Co., Bank of America Corp. and Wells Fargo WFC $-9.83 \%$ \& Co. and Citigroup Inc. C -13.37\% fell between 5\% and 7\%. Fed officials indicated that short-term rates would likely remain near zero through 2022, citing the coronavirus pandemic's potential to do long-term damage to the U.S. economy and a yearlong labor-market recovery. "We're not thinking about raising rates. We're not even thinking about raising rates," said Fed Chairman Jerome Powell. See, "Bank Stocks Fall After Fed Projects No Rate Increases", https://www.wsj.com/articles/bank-stocks-fall-after-fed-projects-no-rate-increases-

11591891477 ?mod=md usstk news . The DJIA continues to rise. It reached 34,996.18 (7/12/2021) and a week later (7/19/2021), it fell to 33,962.04. On July 23, 2021, it was 35,061.55. See, Yahoo/ Finance.

20 The discount rate was $\left(i_{D R}=0.25 \%\right)$. Updated: July 19, 2021.

See, https://fred.stlouisfed.org/series/INTDSRUSM193N

${ }^{21}$ See, "Fed sets $0 \%$ reserve requirement ratio, urges banks to use capital, liquidity buffers to bolster lending in face of coronavirus". https://www.regreport.info/2020/03/15/fed-sets-0-reserverequirement-ratio-urges-banks-to-use-capital-liquidity-buffers-to-bolster-lending-in-face-of-

coronavirus/ . The reserve requirements started on December 23, 1913 and were abolished on March 26, 2020. See also,

https://www.federalreserve.gov/newsevents/pressreleases/monetary20200315b.htm

${ }^{22}$ Total Reserves of Depository Institutions. See, https://fred.stlouisfed.org/series/TOTRESNS 
$\left(i_{I O R}=0.15 \%\right) .^{23}$ The 3-month T-Bill rate (6/9/2020) was $i_{R F}=0.19 \%$ and in the secondary market, $i_{R F}=0.10 \%$; in November 2020, it became $i_{R F}=0.09 \%$; and in March 2021, it was $i_{R F}=0.04 \% ;^{24}$ on July 14, 2021, it was $i_{R F}=0.06 \%$ and $0.05 \%$ in the secondary market; ${ }^{25}$ money is free, due to its excess supply. ${ }^{26}$ But is this monetary policy effective, fair, ethical, and riskless? What are the social benefits of this policy? The first perspective of required reserves concerns risk. Is the zero reserve requirement ratio riskless? The reason banks hold reserves is to have enough liquidity, in case that synchronization ${ }^{27}$ fails. If synchronization exists, the bank does not need to hold a lot in reserves; it can take the money that someone has deposited and give it to the other person, when he comes in to make a withdrawal. This allows the bank to devote the bulk of its funds to long-term investments that pay high rates in interest.

${ }^{23}$ Interest rate on excess reserves was $\left(i_{I O R}=0.10 \%\right)$ with March 19, 2021 and became $0.15 \%$ with July 2021.

See, https://fred.stlouisfed.org/series/IOER

${ }^{24}$ See, 3-month Treasury Bills-Secondary Market.

http://economagic.com/em-cgi/data.exe/fedbog/tbsm3m

${ }_{25} \mathrm{See}, \mathrm{https} / / / \mathrm{www}$.treasury.gov/resource-center/data-chart-center/interestrates/Pages/TextView.aspx?data=billrates and https://fred.stlouisfed.org/series/DTB3

${ }_{26}$ With June 1,2020 , the M2 was $\$ 18.153$ trillion, with November 23, it became $\$ 19.121$ trillion, with February 23, 2021, it was $\$ 19.414$ trillion, with March 25, 2021, it had reached $\$ 19.670$ trillion and with June 22, 2921, it was \$20.278 trillion. With 2020:Q1, the GDP was \$18.975 trillion, with 2020:Q3, it was \$18.584 trillion, with 2020:Q4, it was \$21.49 trillion, with 2021:Q1, it was \$22.675 trillion and with 2021:Q2 it was \$22.72 trillion. (Economagic.com)

and https://www.bea.gov/news/2021/gross-domestic-product-fourth-quarter-and-year-2020second-estimate . Also, https://www.bea.gov/news/2021/gross-domestic-product-second-quarter2021-advance-estimate-and-annual-update

27 Synchronization means that on a given day, people are depositing about as much money as they are withdrawing. 


\section{Fed's Objectives, Tools, and Discretion vs Rules}

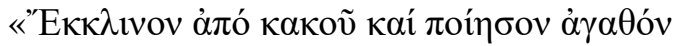

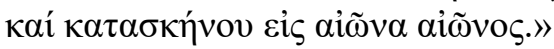
$\Psi \alpha \lambda \mu$ ó 36,27

The objectives of the Fed are: (1) Price stability by maintaining a sustained low inflation rate $(\pi \leq 2 \%)$. (2) Maximum employment (but not full employment, $u \cong u^{N}$ ). These two goals of price stability and maximum sustainable employment are known collectively as the "dual mandate". ${ }^{28}$

(3) A Stable real economy, maximum sustained output ( $\left.\bar{g}_{G D P}\right)$. (4) Stability of financial markets. (5) Moderate long-term interest rate $\left(\bar{i}_{L-T}\right)$. (6) Equilibrium in the Balance of Payment ( $C A \cong 0$ ) and stability of the foreign exchange rate $(\bar{e})$. Then, the Fed with its monetary policy is expected to smooth the business cycle and offset shocks to the economy. The best could have been, if it was possible to prevent financial and economic crisis; but this is beyond the abilities of any public policy in our complex and interdependent economy. Are the goals of maximum employment, stable prices, moderate interest rates and financial stability compatible with one another? Many people believe that they are not in concordance. Conventional wisdom holds that if monetary policy is too focused on controlling inflation; then, employment and output growth will likely fall below their potential, but financial markets will be more stable than they otherwise could be, due to liquidity control. Lately, we see very few (only one) of these objectives to be satisfied, even with the new monetary policy tools.

28 The Federal Reserve's Federal Open Market Committee (FOMC) has translated these broad concepts into specific longer-run goals and strategies. (i) Price stability: Inflation at the rate of $2 \%$, as measured by the annual change in the Price Index for Personal Consumption Expenditures (PCE), is most consistent over the longer run with the Federal Reserve's statutory mandate. (ii) Maximum sustainable employment: Many nonmonetary factors affect the structure and dynamics of the labor market, and these may change over time and may not be measurable directly. Accordingly, specifying an explicit goal for employment is not appropriate. Instead, the Committee's decisions must be informed by a wide range of labor market indicators. Information about FOMC participants' estimates of the longer-run normal rate of unemployment consistent with the employment mandate can be found in the Summary of Economic Projections (SEP). Most recently, the median Committee participant estimated this rate to be $4.1 \%$. See, "The Federal Reserve's Dual Mandate", https://www.chicagofed.org/research/dual-mandate/dual-mandate 
Inflation is going up, ${ }^{29}$ unemployment is high, ${ }^{30}$ production very low, ${ }^{31}$ financial markets very unstable with the creation of an enormous bubble, ${ }^{32}$ huge trade deficits $^{33}$ and depreciation of the dollar, Graph 1. There is one objective that it is satisfied; the long-term interest rate, which is still low. ${ }^{34}$

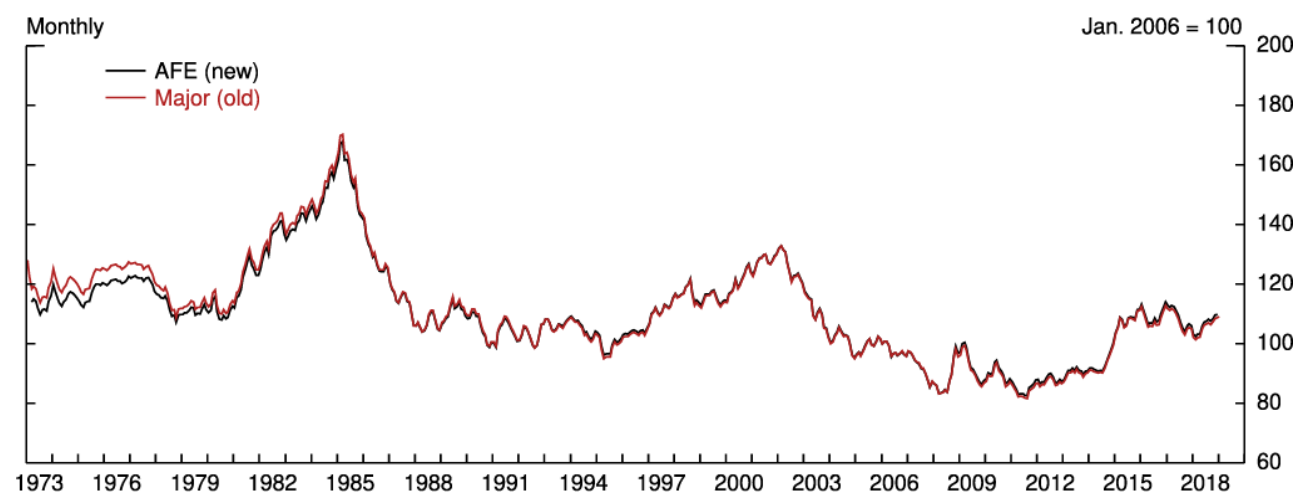

Graph 1: Nominal AFE Dollar Indexes (FC/\$)

Note: --- AFE (new)

--- Major (old)

Source: https://www.federalreserve.gov/econres/notes/feds-notes/revisions-to-the-federal-reservedollar-indexes-20190115.htm

Banks hold currency (vault cash) and reserves (required reserves, $R_{R}$, and excess reserves, $R_{E}$ ). The Fed supplies reserves into the banking system through open

${ }^{29}$ In May 2021, the official $\pi=5 \%$, https://www.usinflationcalculator.com/inflation/currentinflation-rates/.The SGS inflation was $\pi=13 \%$, http://www.shadowstats.com/alternate data/inflation-charts

${ }_{30}$ In May, the official u $=5.8 \%$, https://tradingeconomics.com/united-states/unemployment-rate . The SGS was $\mathrm{u}=26 \%$, http://www.shadowstats.com/alternate data/unemployment-charts

31 With 2021:Q1, the real GDP was \$19,09 trillion and with 2021:Q2, it was \$22.72 trillion. https://fred.stlouisfed.org/series/GDPC1 This growth was $6.3 \%$ in the $1^{\text {st }}$ quarter and $6.5 \%$ in the $2^{\text {nd }}$ quarter of 2021. https://tradingeconomics.com/united-states/gdp-growth . The real GDP and its L-T trend appear in Figure 2.

32 The DJIA from 6,547.05 (3/9/2009) reached 34,777.76 (5/7/2021); a growth of 28,230.71 points or $431.20 \%$ (35.43\% p.a.). See, Yahoo/Finance.

${ }^{33}$ In 2018, TA $=-\$ 878.749$ billion; in 2019, $\mathrm{TA}=-861.514$ billion; in 2020, $\mathrm{TA}=-922.026$ billion. See, https://www.bea.gov/sites/default/files/2021-06/trans121-annual-hist.pdf

${ }^{34}$ Daily Treasury Yield Curve Rates (06/24/2021):

$\mathrm{i}_{1 \mathrm{M}}=0.05 \%, \quad \mathrm{i}_{2 \mathrm{M}}=0.05 \%, \quad \mathrm{i}_{3 \mathrm{M}}=0.05 \%, \quad \mathrm{i}_{6 \mathrm{M}}=0.05 \%, \quad \mathrm{i}_{1 \mathrm{Y}}=0.08 \%, \quad \mathrm{i}_{2 \mathrm{Y}}=0.26 \%, \quad \mathrm{i}_{3 \mathrm{Y}}=$ $0.48 \%, \quad \mathrm{i}_{5 \mathrm{Y}}=0.90 \%$,

$\mathrm{i}_{7 \mathrm{Y}}=1.26 \%, \quad \mathrm{i}_{10 \mathrm{Y}}=1.49 \%, \quad \mathrm{i}_{20 \mathrm{Y}}=2.03 \%, \quad \mathrm{i}_{30 \mathrm{Y}}=2.10 \%$,

See, https://www.treasury.gov/resource-center/data-chart-center/interest-

rates/pages/textview.aspx?data $=$ yield

Mortgage rates: $\mathrm{i}_{30 \mathrm{YM}}=2.849 \%$ and $\mathrm{i}_{15 \mathrm{YM}}=2.134 \%$.

See, https://www.nerdwallet.com/mortgages/mortgage-rates . See, Kallianiotis (2021a). 
market operations (non-borrowing reserves, $R^{*}$ ) by purchasing securities in the open market (primary dealers) or by making loans (borrowing reserves, $R_{B}$ ) through the discount window. An open market purchase ( OMP) leads to an expansion of reserves in the banking system and increases domestic credit $(D C)$ in Fed's Balance Sheet. ${ }^{35}$ An open market sale ( $O M S$ ) leads to a contraction of reserves in the banking system and reduction in domestic credit. Banks' reserves are increasing when they borrow from Fed's discount window (borrowed reserves, $R_{B}$ ) by paying an interest rate (the discount rate, $i_{D R}$ ). This discount loan leads to an expansion of reserves and increases liquidity in the banking system. The opposite effects take place, when the bank repays the discount loan.

Now, proposals for policy rules are largely based on empirical research using economic models. ${ }^{36}$ These models demonstrate the advantages of a-systematic approach to monetary policy and the proposed rules have changed and improved over time. Rules' objective is to help central bankers formulate monetary policy as they operate in domestic financial markets, institutions, and the economy. However, the line of demarcation between rules and discretion is difficult to establish in practice, which makes comparison of the two approaches difficult. Historically, research on policy rules has had an impact on the practice of central banking and its efficiency. Economic research also shows that monetary policy has not been enough to prevent swings away from rules-based policy and smooth the business cycle. Then, policy rules can improve effectiveness of monetary policy.

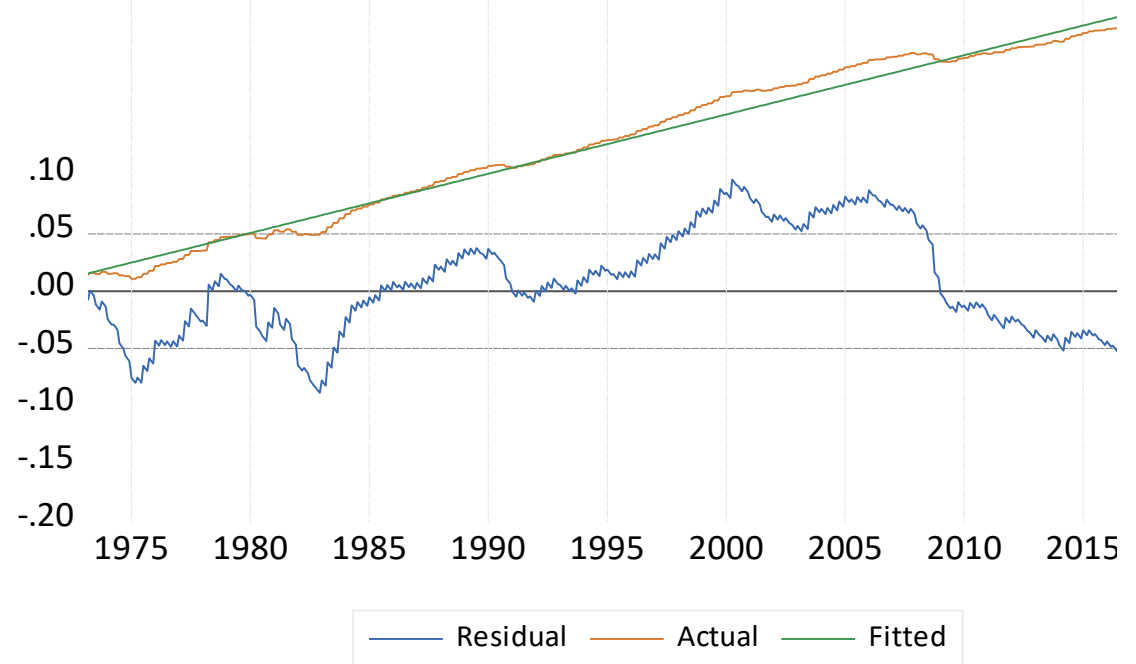

Figure 2: The Real GDP and its L-T Trend

Note: Actual $=$ LUSRGDP2012, Fitted $=$ L-T trend.

Source: Economagic.com

35 See, "Factors Affecting Reserve Balances of Depository Institutions", https://www.federalreserve.gov/releases/h41/current/h41.htm

36 See, Taylor (1993), Bullard (2018a and b), and Kallianiotis (2019c). 
"In contrast, in the case of more discretionary policy making, decisions are less predictable and more ad hoc, and they tend to focus on short-term fine-tuning. Policymakers show little interest in coming to agreement about an overall contingency strategy for setting the instruments of policy, and the historical paths for the instruments are not well described by stable algebraic relationships." ${ }^{37}$ In reality, rules or strategies are simply ways to help central bankers improve monetary policy as they operate and communicate with markets, citizens, and all the sectors of the economy in a democracy, and interact in a global monetary system. Experience, over time, shows that rules do improve financial stability and economic performance and thereby, improve people's lives (citizens' welfare).

In the U. S., where Congress has responsibility under the Constitution, the value of considering some legislation that would enhance reporting and discussions with Congress and the public about the strategy of monetary policy of the private central bank is necessary. A debate between rules and discretion will be helpful for the policy makers, too. The economic research has shown that it is important the U.S. monetary policy and the international monetary system must have a rules-based strategy, but it is difficult to be imposed. A rational discussion and more empirical work can contribute to the improvement of monetary policy through rules, which can move us onward to the goal of a better performing and fairer economy.

\subsection{Open Market Operations}

Open market operations (OMOs) ${ }^{38}$ are the purchase and sale of securities (government bonds, agency bonds, and mortgage-back securities) in the open market by the central bank. The OMO is a key tool used by the Federal Reserve, daily, in the implementation of monetary policy. The short-term objective for OMO is specified by the Federal Open Market Committee (FOMC). ${ }^{39}$ Before the global financial crisis in 2008, the Federal Reserve used OMOs to adjust the supply of reserve balances and to keep the federal funds rate $\left(i_{F F}\right)$ around the target ( $0.00 \%-0.25 \%$ from December 16, 2008 to December 16, 2015 and from March 16, 2020 to present $)^{40}$ established by the FOMC.

The open market operations and the discount lending affect the federal funds rate by injecting reserves into the banking system; thereby changing the supply of reserves $\left(R^{s}\right)$. The reserve requirements $\left(R_{R}\right)$ were affecting the federal funds rate by changing the demand for reserves $\left(R^{d}\right)$. The federal funds rate is affecting the interest rate paid on reserves. An open market purchase (OMP) leads to a greater quantity of reserves supplied and shifts the $R^{s}$ curve from point $\mathrm{E}_{1}$ to the right to

\footnotetext{
37 See, Taylor (2017).

38 See, "Open market operations (OMOs)". https://www.federalreserve.gov/monetarypolicy/openmarket.htm

39 See, Federal Open Market Committee (FOMC), https://www.federalreserve.gov/monetarypolicy/fomc.htm

${ }_{40}$ See, FOMC's target federal funds rate or range, change (basis points) and level. https://www.federalreserve.gov/monetarypolicy/openmarket.htm
} 
point $E_{2}$, Figure 1 . The amount of non-borrowed reserves increases to $R_{2}^{*}$ and the $i_{F F_{1}}$ falls to $i_{F F_{2}}$. An open market sale (OMS) decreases the quantity of nonborrowed reserves supplied and the supply curve shifts to the left and the $i_{F F}$ increases, Figure 1.

$$
\begin{gathered}
\text { OMP } \Rightarrow \text { Securities } \uparrow \Rightarrow R^{*} \uparrow \Rightarrow R^{s} \uparrow \Rightarrow i_{F F} \downarrow \\
\text { OMS } \Rightarrow \text { Securities } \downarrow \Rightarrow R^{*} \downarrow \Rightarrow R^{s} \downarrow \Rightarrow i_{F F} \uparrow
\end{gathered}
$$

In a repurchase agreement (repo), ${ }^{41}$ the Fed purchases Treasury securities with an agreement that the seller will repurchase them in a short period (from 1 to 15 days). Thus, the repo is a temporary OMP and is used for a defensive OMP, which will be reversed in a few days. When the Fed wants to conduct a temporary OMS, it engages in a reverse repurchase agreement (matched sale-purchase transaction), in which the Fed sells securities and the buyer agrees to sell them back to the Fed in a short period.

\subsection{The Discount Window and Discount Rate}

Federal Reserve lending to depository institutions (the "discount window") plays an important role in supporting the liquidity and stability of the banking system and contributes to the effective implementation of monetary policy. By providing ready access to funding, the discount window helps depository institutions manage their liquidity risks efficiently and avoid actions that have negative consequences for their customers, such as withdrawing their deposits and supplying credit during times of market stress. Thus, the discount window supports the smooth flow of credit to households and businesses. The discount rate $\left(i_{D R}\right)^{42}$ is the interest rate charged to commercial banks and other depository institutions on loans they receive from their regional Federal Reserve Bank's lending facility, the discount window. All discount window loans are fully secured. Lately, with this enormous liquidity

${ }^{41}$ See, "Repurchase Agreement Operational Details", https://www.newyorkfed.org/markets/domestic-market-operations/monetary-policyimplementation/repo-reverse-repo-agreements/repurchase-agreement-operational-details . See also, "Repo and Reverse Repo Agreements", https://www.newyorkfed.org/markets/domestic-market-operations/monetary-policyimplementation/repo-reverse-repo-agreements

42 See, "Discount Rate", https://www.investopedia.com/terms/d/discountrate.asp\#: :text=While\%20the\%20discount\%20rat es $\% 20$ for $\% 20$ the $\% 20$ first $\% 20$ two, based $\% 20$ on $\% 20$ the $\% 20$ prevailing $\% 20$ rates $\% 20$ in $\% 20$ the $\% 20$ market. Now, it is $i_{D R}=0.25 \%$. See, https://www.nasdaq.com/market-activity/fixedincome/disc/historical . See also, https://www.bankrate.com/rates/interest-rates/federal-discountrate.aspx . The 3-month T-Bill rate was $i_{R F}=0.08 \%$ and lately, it became $i_{R F}=0.04 \%$. See, https://ycharts.com/indicators $/ 3$ month $\mathrm{t}$ bill .

Then, $i_{D R}=i_{R F}+0.20 \% \cong 0.08 \%+0.20 \% \cong 0.25 \%$ or $i_{D R}=i_{R F}+0.20 \% \cong 0.04 \%+0.20 \% \cong 0.25 \%$. See, current discount rate, https://www.frbdiscountwindow.org/pages/discount-rates/current-discount-rates 
by the Fed, which supplies non-borrowed reserves $\left(\mathrm{R}^{*}\right)$, point $\mathrm{E}_{4}$, Figure 1, there is no need for borrowing from the discount window, there is free money $\left(i_{F F}^{e f f}=0.08 \%\right) .^{43}$

The discount rate was $1 \%$ above the target federal funds rate $\left(i_{D R}=\bar{i}_{F F}+1 \%\right)$; but due to the global financial crisis in 2007, the Fed lowered the $i_{D R}$ to $0.50 \%$ above the federal funds rate $\left(i_{D R}=\bar{i}_{F F}+0.50 \%\right)$ and in March 2008, it was reduced to $0.25 \%$ above the federal funds rate that it is today: $i_{D R}=\bar{i}_{F F}+0.25 \%=0.00 \%+0.25 \%=0.25 \%$. The use of the discount window was limited because it had a stigma on the banks that they are in trouble and have to borrow from the Fed. But, banks should use the discount window without making this action a public knowledge. ${ }^{44}$

Of course, the Fed was using the discount window to influence the amount of reserves $\left(R_{R}\right)$ and also to prevent financial panics. But, this facility increases the social cost because banks are willing to take on more risk knowing that the Fed (and the FDIC) will come to their rescue. Hence, banks take on more risk, as it happened before 2008, and exposed taxpayers to enormous losses by bailing them out. This moral hazard problem is a serious social and ethical problem of our unregulated and corrupted banks and it is related to the "too big to fail" philosophy.

\subsection{Reserve Requirements}

The Federal Reserve Act ${ }^{45}$ authorizes the Board to establish reserve requirements $\left(R_{R}\right)$ within specified ranges for purposes of implementing monetary policy on certain types of deposits and other liabilities of depository institutions. ${ }^{46}$ For many years, reserve requirements played a central role in the implementation of monetary policy by creating a stable demand for reserves. In January 2019, the FOMC announced its intention to implement monetary policy in an ample reserves regime. As announced on March 15, 2020, ${ }^{47}$ the Board reduced reserve requirement ratios $\left(r_{R}\right)$ to zero percent effective March 26, 2020. This action eliminated reserve requirements $\left(R_{R}=0\right)$ for all depository institutions and increased their riskiness.

\footnotetext{
43 See, "Effective Federal Funds Rate", https://fred.stlouisfed.org/series/FEDFUNDS

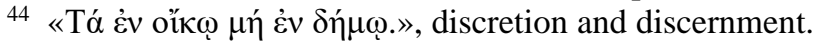

${ }^{45}$ See, Federal Reserve Act. https://www.federalreserve.gov/aboutthefed/fract.htm

46 The reserve requirements (reserve requirement ratio) were: Net transaction accounts from $\$ 0$ to $\$ 10.3$ million, $r_{R}=0 \%$; more than $\$ 10.3$ million to $\$ 44.4$ million, $r_{R}=3 \%$; and more than $\$ 44.4$ million, $r_{R}=10 \%$. Since March 26, 2020, the $r_{R}=0 \%$. See, "Reserve Requirements", https://www.educba.com/reserve-requirements/. In some countries, in 1970s, there were reserve requirements on loans to importers, too. These reserves were increasing the cost of borrowing and discouraged imports, which was a trade policy for the country and was improving the trade account. In those days, public policies were national; lately, they became global, anti-national.

47 See, Federal Reserve Actions to Support the Flow of Credit to Households and Businesses, https://www.federalreserve.gov/newsevents/pressreleases/monetary20200315b.htm
} 


\subsection{Interest on Required and Excess Reserve Balances}

The Federal Reserve Bank pays interest on required reserve balances and on excess reserve balances (IOR). ${ }^{48}$ The Financial Services Regulatory Relief Act of $2006^{49}$ authorized the Federal Reserve Banks to pay interest on balances held by or on behalf of depository institutions at Reserve Banks, subject to regulations of the Board of Governors, effective October 1, 2011. The effective date of this authority was advanced to October 1, 2008, by the Emergency Economic Stabilization Act of $2008 .^{50}$

The cost of holding reserves is their opportunity cost, the interest rate that could have been earned on lending these reserves out to business and individual borrowers. But, after 2008 and up to now, banks are receiving interest on their reserve balances; this IOR is:

$$
I O R=R_{T} i_{I O R}
$$

The supply of reserves $\left(R^{s}\right)$ can be broken into two components, the amount of reserves supplying by the Fed's open market operations, non-borrowed reserves $\left(R^{*}\right)$ and the amount of reserves borrowed from the Fed, borrowed reserves $\left(R_{B}\right)$, eq. (2). The cost of borrowing from the Fed is the discount rate $\left(i_{D R}\right)$. If the $i_{F F}<i_{D R}$, banks will not borrow from the Fed's discount window and $R_{B}=0$; they will borrow from the federal funds market. Then, $R^{s}=R^{*}$.

$$
R^{s}=R^{*}+R_{B}
$$

If the federal funds rate $\left(i_{F F_{0}}\right)$ is at the level of the flat demand for reserves $\left(\mathrm{R}^{\mathrm{d}}\right)$, equilibrium point $E_{3}$, open market operations have no effect on the federal funds rate; from $E_{3}$, it goes to $E_{4}$ and the federal funds rate stays at $i_{F F_{0}}$, Figure 1. This is a floor for the federal funds rate, as it is now $\left(i_{F F}=0 \%\right)$. There is only an increase in reserves $(R)$, which raises the monetary base $(M B)$ and through the money multiplier $\left(m_{M}\right)$ increases the money supply $\left(M^{s}\right)$; contributing enormous liquidity in the economy, bubbles in the stock market, and high inflation expectations. The risk is going up in the financial market because the bubble can very easily burst.

\footnotetext{
48 The Fed's interest on reserves was, $i_{I O R}=0.10 \%$ since $3 / 16 / 2020$. Now, since $6 / 17 / 2021$, it is $i_{\text {IOR }}=0.15 \%$. See, https://www.federalreserve.gov/monetarypolicy/reqresbalances.htm

${ }^{49}$ See, FINANCIAL SERVICES REGULATORY RELIEF ACT OF 2006, https://www.congress.gov/109/plaws/publ351/PLAW-109publ351.pdf

${ }^{50}$ DIVISION A - EMERGENCY ECONOMIC STABILIZATION, https://www.congress.gov/110/plaws/publ343/PLAW-110publ343.pdf
} 


$$
R^{d} \text { flat section } \Rightarrow \text { OMP } \Rightarrow \text { Securities } \uparrow \Rightarrow R^{*} \uparrow \Rightarrow R_{3}^{*} \Rightarrow R_{4}^{*} \Rightarrow i_{F F_{0}}(\text { cons } \tan t)
$$

When the Fed reduces or increases the discount rate, but $i_{D R}>i_{F F}$, there are no effects on the federal funds rate and no effect on the reserves. Now, in case that a reduction of the discount rate takes place and $i_{D R}=i_{F F}$, the supply of reserves will fall $\left(R^{s} \downarrow\right)$ and the borrowed reserves increase $\left(R_{B} \uparrow\right)$.

$$
i_{D R} \downarrow \Rightarrow Q_{R_{B}}^{d} \uparrow \Rightarrow R^{d} \uparrow \Rightarrow R \uparrow \Rightarrow M B \uparrow \Rightarrow M^{s} \uparrow
$$

When the required reserve ratio $\left(r_{R}\right)$ increases, required reserves $\left(R_{R}\right)$ increase, and the quantities of reserves demanded $\left(Q_{R}^{d}\right)$ increases and the federal funds rate $\left(i_{F F}\right)$ increases. The opposite if $r_{R}$ falls.

$$
r_{R} \uparrow \Rightarrow R_{R} \uparrow \Rightarrow Q_{R}^{d} \uparrow \Rightarrow i_{F F} \uparrow
$$

\subsection{Overnight Reverse Repurchase Agreement Facility}

In the Policy Normalization Principles and Plans ${ }^{51}$ announced on September 17, 2014, the Federal Open Market Committee ( FOMC ) indicated that it intended to use an overnight reverse repurchase agreement ( $O N R R P$ ) facility if needed, as a supplementary policy tool to help control the federal funds rate and keep it in the target range set by the FOMC. The Committee stated that it would use an ON RRP facility only to the extent that it will be necessary and will phase it out when it is no longer needed to help control the funds rate. When the Federal Reserve conducts an overnight $R R P$, it sells a security to an eligible counterparty and simultaneously agrees to buy the security back the next day. The Federal Reserve currently conducts $O N R R P$ operations with many counterparties, covering a wide range of entities, ${ }^{52}$ as it is discussed below and it is shown in Figure 3.

\subsection{Margin Requirements}

Under Regulation $\mathrm{T}$, a security can generally be classified as belonging to one of three categories: (1) margin, (2) non-margin, and (3) exempted security. U.S. broker-dealers are prohibited from extending credit against non-margin securities, unless the loan is a non-purpose loan, that is, for a purpose other than buying,

51 See, "FOMC Communications Related to Policy Normalization". On October 11, 2019, the FOMC released a statement that outlined its plans to ensure that the level of reserves in the banking system remains ample. https://www.federalreserve.gov/monetarypolicy/policy-normalization.htm

52 See, "Reverse Repo Counterparties". https://www.newyorkfed.org/markets/rrp_counterparties.html 
carrying, or trading in securities (see, section 220.6(e) of Regulation T) ${ }^{53}$ Brokerdealers may extend purpose credit against margin and exempted securities. Exempted securities are defined in section 3(a)(12) of the Act to include government and municipal securities. Also, broker-dealers may extend up to 50\% loan value against margin equity securities. ${ }^{54}$ Further, broker dealers may extend "good faith" credit against debt and exempted securities. Margin requirements $\left(r_{m}\right)$ are listed in section 220.12 of Regulation T. The $r_{m}=50 \%$ since $1974 .{ }^{55}$ Then, it is an ineffective tool because it is not in use. This low margin requirement generates an artificial high demand for financial assets and is contributing enormously to the financial bubble, to the financial market risk, and to enormous bail out cost for saving banks' during a financial crisis. (Sic).

\subsection{New Monetary Policy Instruments}

Before 2007, the Fed implemented monetary policy with limited reserves in the banking system $\left(R^{*}+R_{B}=R_{T}^{S}\right)$ and relied on $O M O$ as its key instrument (tool). After the financial crisis of 2008, the Fed implements monetary policy with ample reserves and relies on interest on reserves (IOR).

$$
\begin{aligned}
& \text { FOMC } \Rightarrow \text { sets } \Rightarrow \bar{i}_{F F_{t}} \Rightarrow \text { implementaion regime } \Rightarrow i_{S-T_{t}} \text { and } i_{S-T_{t+1}} \Rightarrow i_{L-T_{t}} \Rightarrow \\
& \text { and financialconditions } \Rightarrow C \text { and } I \Rightarrow Q \Rightarrow u^{N} \text { and } \bar{P}
\end{aligned}
$$

Banks held reserves to meet the Fed's regulatory reserve requirements $\left(R_{R}\right)$ and some excess reserves $\left(R_{E}\right)$ to meet the banking demands of their customers. ${ }^{56}$ The interest on reserves $\left(R_{R}+R_{E}=R_{T}^{d}\right)$ was zero $\left(i_{I O R}=0\right)$. When banks needed extra

\footnotetext{
${ }^{53}$ Regulation T is a collection of provisions that govern investors' cash accounts and the amount of credit that brokerage firms and dealers may extend to customers for the purchase of securities. According to Regulation T, an investor may borrow up to $50 \%$ of the purchase price of securities that can be bought using a loan from a broker or dealer. The remaining $50 \%$ of the price must be funded with cash. See,

https://web.archive.org/web/20170710145033/https://www.ecfr.gov/cgi-bin/text$\underline{\mathrm{idx}}$ ?SID=b2233140b41b2612baec30f988b8357c\&mc=true\&node=se12.3.220 112\&rgn=div8 Also see, https://web.archive.org/web/20180621064548/https://www.ecfr.gov/cgi-bin/textidx?tpl=\%2Fecfrbrowse\%2FTitle12\%2F12cfr220_main 02.tpl And https://www.investopedia.com/terms/r/regulationt.asp , Further, Margin Requirements, https://www.firstrade.com/content/en-us/education/margin/marginrequirements/ ${ }^{54} \mathrm{See}$, https://www.federalreserve.gov/supervisionreg/legalinterpretations/margin_requirements20080305 .pdf . See also, https://www.finra.org/rules-guidance/key-topics/margin-accounts\#overview . In addition, https://www.federalreserve.gov/supervisionreg/reglisting.htm

55 The Federal Reserve's margin requirements for purchasing equities with borrowed funds has been at 50\% since 1974. See. https://www.frbsf.org/economic-research/publications/economicletter/2000/march/margin-requirements-as-a-policy-tool/

${ }^{56}$ See, Kallianiotis (2017a).
} 
reserves to meet their demands, they were borrowing these reserves from the federal funds market. If banks had excess reserves, they could lend them in the federal funds market at the $i_{F F}^{e f f}$. The demand and supply of reserves are depicted in Figure 1. To raise the $i_{F F}$, the Fed decreases the supply of reserves $\left(R_{1}^{s}\right)$ by selling U.S. Treasury securities in the open market. To lower the $i_{F F}$, the Fed increases the supply of reserves $\left(R_{2}^{s}\right)$ by buying government securities in the open market.

Banks were before minimizing their holdings of excess reserves because $i_{\text {IOER }}=0$. Now, with $i_{I O E R}>0$, banks have an incentive to hold more excess reserves. The $i_{\text {IOER }}$ became a tool to influence banks to hold more excess reserves at the Fed. The Fed has since that time the $i_{I O E R}$ as a new tool for implementing monetary policy. Since November 2008, $i_{\text {IORR }}=i_{\text {IOER }}$ and since March 26, 2020, the Fed abandoned the required reserves $\left(R_{R}=0\right) .{ }^{57}$ Then, IORR was made effectiveness irrelevant. The Fed shifted to an ample-reserves framework and reserve requirements are not anymore a tool of monetary policy. Thus, now, we have only $\operatorname{IOR}\left(i_{I O R}\right)$. The reserves are still remained "ample", 58 Figure 3.

When there is a large quantity of reserves in the banking system, as it is lately, Figure 3, the Fed can no longer influence the $i_{F F}$ by making small changes in the supply of reserves $\left(R^{s}\right)$. Why we need all these non-borrowing reserves $\left(R^{*}\right)$ ? What is the reason of this enormous liquidity with the economy lockdown, an enormous demand for imports, ${ }^{59}$ and a very anemic $A D$ ? The double digit inflation is already, here. How we will control the bubble in the financial market? The market manipulators will start taking advantage of this situation.

\footnotetext{
57 See, "Reserve Requirements", https://www.federalreserve.gov/monetarypolicy/reservereq.htm ${ }^{58}$ In January 2019, the FOMC released a statement saying, it would continue to implement policy with ample reserves in the long run. See, Board of Governors of the Federal Reserve System. "Statement Regarding Monetary Policy Implementation and Balance Sheet Normalization." Press release, January 30, 2019;

https://www.federalreserve.gov/newsevents/pressreleases/monetary20190130c.htm

More recently, in response to the COVID-19 pandemic, reserves have grown substantially. By May 2020 , reserves expanded and stood above $\$ 3.218$ trillion, at a higher level than their peak during the aftermath of the Great Recession; on January 28, 2021, they were $\$ 3.135$ trillion, on February 23, 2021, they were $\$ 3.154$ trillion, and on March 23, 2021 became $\$ 3.346$ trillion. https://fred.stlouisfed.org/series/TOTRESNS

59 See, "United States Imports", https://tradingeconomics.com/united-states/imports . See also, "List of imports of the United States", https://en.wikipedia.org/wiki/List_of_imports_of the United_States . Further see, "What Are the Top 10 U.S. Imports?", https://traderiskguaranty.com/trgpeak/what-are-the-top-10-u-s-imports/
} 


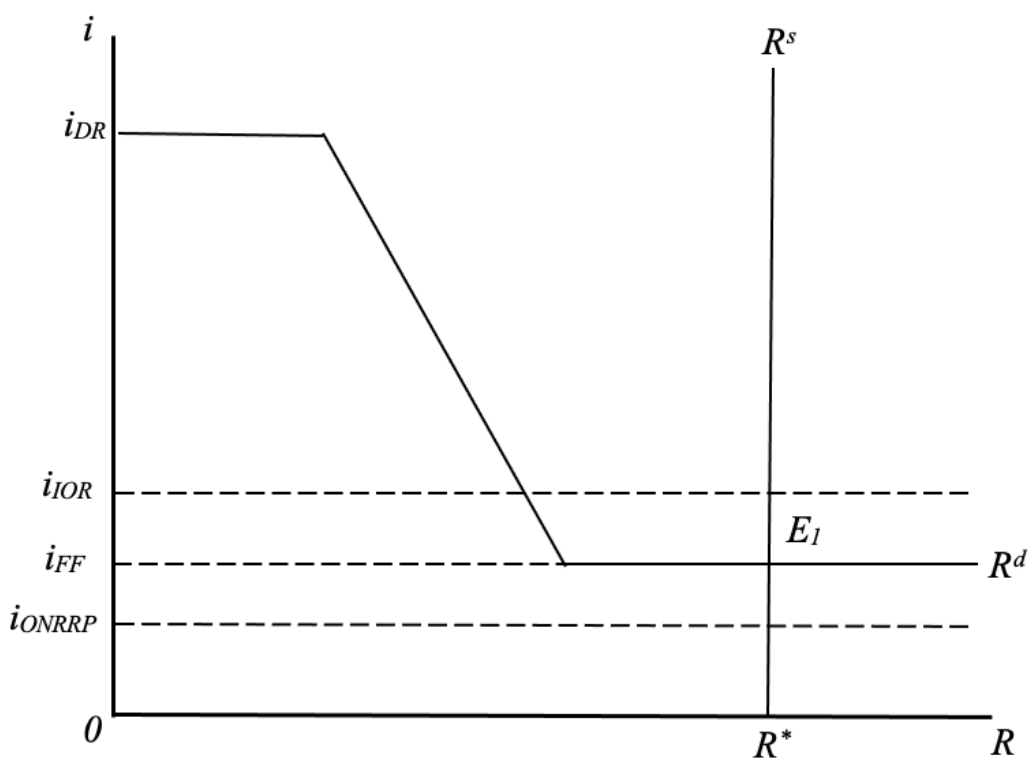

Figure 3: Monetary Policy with Ample Reserves

Note: $i=$ interest rates, $i_{F F}=$ federal funds rate, $i_{D R}=$ discount rate, $R=$ reserves, $R^{d}=$ demand for reserves, $R^{s}=$ supply of reserves, $R^{*}=$ non-borrowed reserves, $E$ = equilibrium $\left(R^{s}=R^{d}\right)$.

The Fed is using, now, its administered rates $\left(i_{I O R}\right.$ and $\left.i_{O N R R P}\right)$ to influence the $i_{F F}$ The demand curve $\left(R^{d}\right)$ turns flat between the new administered rates at point $E_{1}$, Figure 3, which helps to keep the $i_{F F}$ into the FOMC 's target range $(0.00 \%-0.25 \%)$. With these enormous "ample" reserves, the Fed does not need to make daily $O M O(O M P$ or $O M S$ ), as it did before with the limited reserves to hit the $i_{F F}$ target. Now, small shifts of the supply curve $\left(R^{s}\right)$ have no effect on the $i_{F F}$.

The main tool for keeping the $i_{F F}$ on its target and driving the demand curve flat is the $i_{I O R}$. Banks invest their money short-term based on the interest rate and the risk. They can invest in Treasury Bills $\left(i_{R F}=0.04 \%\right)$, by offering loans to banks ( $\left.i_{F F}=0.06 \%\right)$, or by depositing to the Fed $\left(i_{I O R}=0.15 \%\right) .{ }^{60}$ Banks prefer to deposit their money to the Fed because $i_{I O R}$ is higher compared to the alternative S-T investments and it is also a safe overnight investment. ( $\mathrm{Sic}$ ). If the $i_{F F}$ were to fall very far below the $i_{I O R}$, banks would borrow in the federal funds market and deposit those reserves at the Fed, earning a profit (arbitrage, $\pi_{A}$ ) on the difference

60 These rates are with June 30, 2021. The T-Bill rates in the secondary market was, $i_{R F}=0.02 \%$. 
$\left(\pi_{A}=i_{I O R}-i_{F F}\right)$. This arbitrage ensures that the $i_{F F}$ does not fall much below $i_{I O R}$

$$
E X D_{F F} \Rightarrow i_{F F} \uparrow \text { and } \quad E X S_{\text {Reserves }} \Rightarrow i_{I O R} \downarrow
$$

Thus, when the Fed raises or lowers the $i_{I O R}$, the $i_{F F}$ moves up or down, too. Consequently, the Fed can keep the $i_{F F}$ into the target range set by the FOMC through adjustment of the $i_{I O R}$. The Fed sets the $i_{I O R}$ directly, so this interest rate serves as an effective monetary policy tool. Now, this $i_{I O R}{ }^{61}$ is the primary tool used by the Fed for influencing the $i_{F F}$, Figure 3 . The old tools were satisfied the same objective without charging citizens with any cost, as they have to pay, now, the IOR (bail out).

In 2014, the FOMC announced that it will use the Overnight Reverse Repurchase Agreement Facility (ON RRP $)^{62}$ to help control the $i_{F F}$.

This facility is a form of $O M O$, where the Fed interacts with many nonbank financial institutions (large money market funds and government-sponsored enterprises). ${ }^{63}$ When one nonbank financial institution uses the $O N R R P$ facility, it deposits reserves at the Fed overnight receiving securities as collateral. The next day the transaction is "unwound"; 64 the Fed buys back the securities and the institution earns the $i_{O N R R P}$, which the Fed sets, on the cash it deposited at the Fed,

Figure 3.

This investment facility is a risk-free option and these institutions are willing to lend funds to this low rate, the $i_{O N R R P}$, but not lower. For this reason, the $i_{O N R R P}$ acts as a reservation rate and institutions can use it to arbitrage other short-term rates. Thus, the interest rate paid on $O N R R P$ transactions and it is below the $i_{I O R}$, acts like a floor for the $i_{F F}$ and serves as a supplementary policy tool by the Fed, Figure 3.

61 See, Board of Governors of the Federal Reserve System. "Interest on Required Reserve Balances and Excess Balances".

https://www.federalreserve.gov/monetarypolicy/reqresbalances.htm

62 See, Board of Governors of the Federal Reserve System. "Overnight Reverse Repurchase Agreement Facility". https://www.federalreserve.gov/monetarypolicy/overnight-reverserepurchase-agreements.htm.

${ }^{63}$ See, "What Is a Money Market Fund?", https://www.investopedia.com/investing/do-moneymarket-funds-pay/ and "Government-Sponsored Enterprise (GSE)",

https://www.investopedia.com/terms/g/gse.asp . See also, Federal Reserve Bank of New York, "Reverse Repo Counterparties". https://www.newyorkfed.org/markets/rrp_counterparties.

${ }^{64}$ Unwind: To close out a relatively complicated investment position. 


\title{
3. Other Instruments and their Implications
}

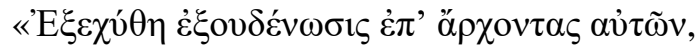

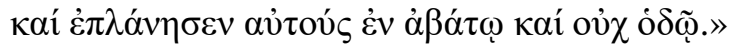
$\Psi \alpha \lambda \mu$ ó $\varsigma 106,40$

\subsection{Quantitative Easing}

Federal Reserve's asset purchases lead to an expansion of its balance sheet, ${ }^{65}$ these asset purchase programs have been given the name "quantitative easing" ( $Q E)$, Graph 2.

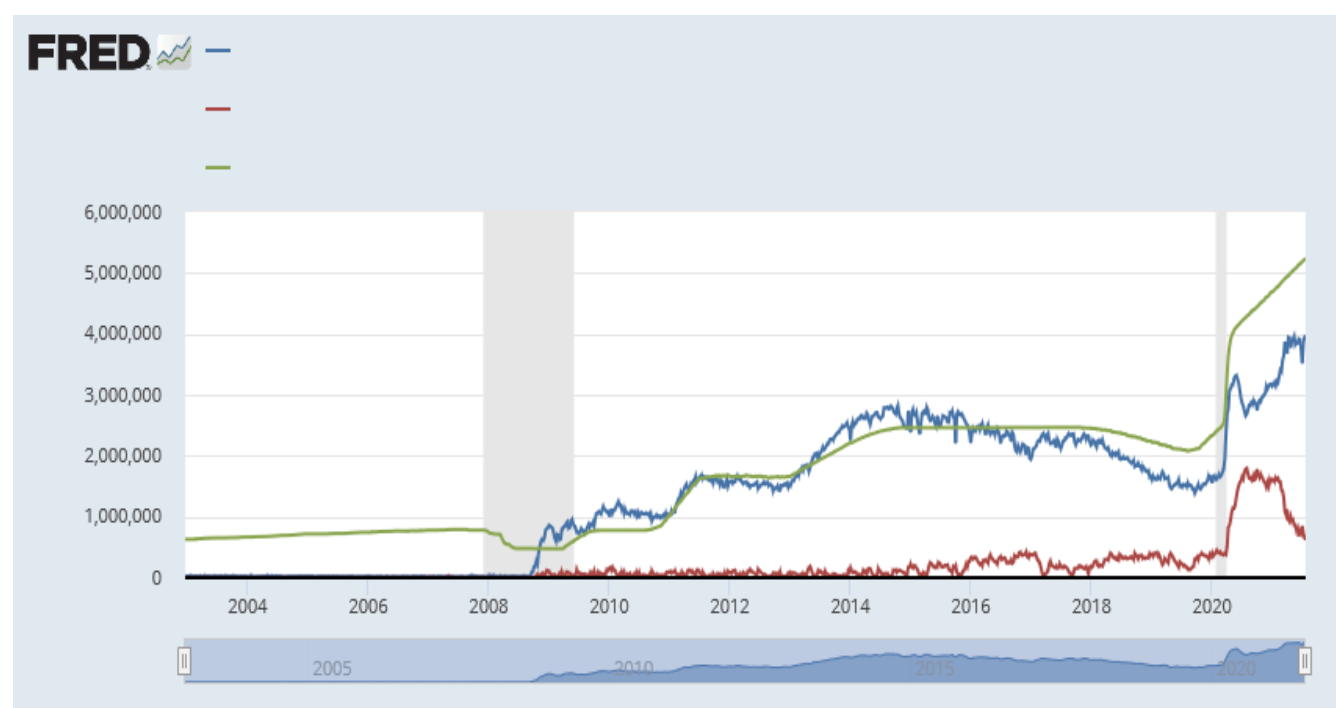

\section{Graph 2: The Fed's Balance Sheet}

Note: ---- Liabilities and Capital: Liabilities: Deposits: Other Deposits Held by Depository Institutions: Wednesday Level.

---- Liabilities and Capital: Liabilities: Deposits with F. R. Banks, Other than Reserve Balances: U.S. Treasury, General Account: Wednesday Level.

---- Assets: Securities Held Outright: U.S. Treasury Securities: Wednesday Level.

Source: FRED, https://fredblog.stlouisfed.org/2020/09/the-feds-balance-sheet/

65 The total assets with January 20, 2021, were: $\$ 7,414.942$ billion, on March 8, 2021, they became $\$ 7,579.901$ billion, and on July 21, 2021 were $\$ 8,174.231$ billion. See, Credit and Liquidity Programs and the Balance Sheet,

https://www.federalreserve.gov/monetarypolicy/bst_recenttrends.htm . See,

https://www.federalreserve.gov/releases/h41/current/h41.htm. On January 20, 2021, the monetary base was $\$ 5,206.6$ billion and the money supply $M 2=\$ 19,548.1$ billion; on February 23,2021 , they were $M B=\$ 5,248$ billion and $M 2=\$ 19,394.6$ billion; on March 23, 2021, they were $M B=\$ 5,447$ billion and $M 2=\$ 19,670$ billion, and on June 22,2021 , they were $\mathrm{MB}=\$ 6,042$ billion and M2 $=\$ 20,278$ billion. Thus, the money multiplier was, $m_{M}=3.75$, then, it fell to $m_{M}$ $=3.70$, further to $m_{M}=3.61$, and recently to $m_{M}=3.36$. See,

https://fred.stlouisfed.org/series/BOGMBASE and https://fred.stlouisfed.org/series/WM2NS 
This quantitative easing policy by the Fed since 2008 has made us all very skeptical. ${ }^{66}$ Is this policy effective? The federal funds rate had hit zero-lowerbound when it fell to zero.

Thus, the expansion of the balance sheet, Graph 2, and the monetary base, could not lower short-term interest rates any further to stimulate the economy, ${ }^{67}$ liquidity trap, Graph 3.

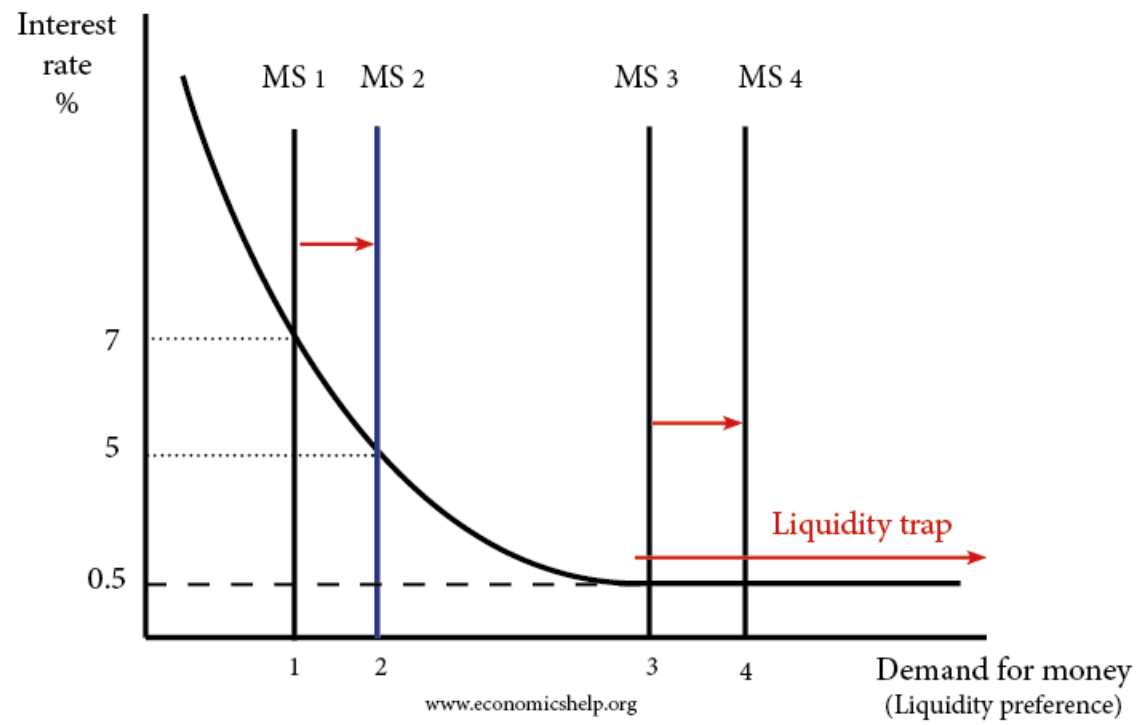

\section{Graph 3: Liquidity Trap}

Source: www. economicshelp.org.

Also, this increase in reserves did not result in an increase in lending; banks added to their holding of excess reserves instead of making loans and with the IOR, this became worse. There is not any reason to lend money, which is risky because they make a return from the Fed (taxpayers), they pay closed to zero interest rate on

66 On October 13, 2014, Bernanke said: "The problem with QE is it works in practice, but it doesn't work in theory. ... I think it's fair to say that, although these [steps] were effective ... Almost all find some impact on bond yields and, less clearly, on ...", See, "US quantitative measures worked in defiance of theory", Financial Times, https://www.ft.com/content/3b164d2e-4f03-11e4-9c88$00144 \mathrm{feab} 7 \mathrm{de}$

67 This is the case of a liquidity trap that is a contradictory economic situation in which interest rates are very low, rendering monetary policy ineffective. First, it described by economist John Maynard Keynes. During a liquidity trap, consumers choose to avoid bonds and keep their funds in cash savings because of the prevailing belief that interest rates could soon rise (which would push bond prices down). Because bond prices have an inverse relationship to interest rates, many consumers do not want to hold an asset with a price that is expected to decline. At the same time, central bank efforts to spur economic activity are hampered as they are unable to lower interest rates further to incentivize investors and consumers. Lately, we have an employment stimulus trap, which keep people away from work because the unemployment insurance compensation is higher than the minimum wages. Then, the easy monetary policy is not effective on employment and production. 
deposits $\left(i_{D}=0.05 \%\right)$ and there is also no demand for loans by businesses, due to recession, closedowns, threats of a new Delta variant of virus, and a vaccine coercion. Then, this policy is ineffective at stimulating the economy.

The long-term interest rate fell, but the aggregate demand $(A D)$ was and it is still (now with the lockdowns and the other crackdowns on people's freedoms) very low.

$$
\begin{aligned}
& \text { purchaseof } L-T \text { gov't and mortgage-backedsecurities (primary dealers) } \Rightarrow \\
& \Rightarrow E X D_{\text {Bonds }} \Rightarrow P_{\text {Bonds }} \uparrow \Rightarrow i_{F F} \downarrow \Rightarrow A D=C+I(\text { low }) \Rightarrow g_{G D P}(\text { low }) \Rightarrow u(\text { high })
\end{aligned}
$$

\subsection{Forward Guidance}

The Fed can lower long-term interest rates by keeping the federal funds rate at zero $\left(i_{F F}=0.00 \%\right)$ for a long period of time in order to lower the market's expectations regarding the future short-term interest rates and through them to cause the longterm interest rates to fall. ${ }^{68}$ This strategy is referred to as "forward guidance". The Fed continued to announce that it will keep the interest rate to zero ${ }^{69}$ and longterm interest rates fell, due to forward guidance or due to weakness in the U.S. economy. The monetary policy is too easy and for a very long time; then, we may see high inflation ${ }^{70}$ after the open up of businesses, the trillion of dollars for coronavirus relief, the unemployment compensation programs, the artificial "infrastructure" bill, ${ }^{71}$ and the improvements from this pandemic ${ }^{72}$ (the coronavirus biological warfare). The current bubbles in the financial market and in

68 The short-term interest rates are closed to zero and the long-term ones very low since 2008.

$$
\begin{aligned}
& i_{F F}=0.00 \%-0.25 \%, \quad i_{F F}^{e f f}=0.09 \%, i_{R F}=0.08 \%, i_{M M}=0.10 \%, i_{D}=0.05 \%, \\
& i_{D R}=0.25 \%, i_{5 Y C D}=0.48 \%, \quad i_{C M}=2 \%, i_{P}=3.25 \%, i_{15 Y M}=2.21 \%, i_{30 Y M}=2.77 \%, \\
& i_{2 Y G B}=0.12 \%, i_{5 Y G B}=0.42 \%, i_{10 Y G B}=1.03 \%, i_{30 Y G B}=1.79 \% . \text { See, Wall Street Journal, }
\end{aligned}
$$

January 27, 2021. https://www.newyorkfed.org/markets/reference-rates/effr

69 See, "Jerome Powell Sees Easy-Money Policies Staying in Place". Fed likely to hold interest rates near zero and continue asset purchases for some time, chairman says. Wall Street Journal, February 23, 2021. https://www.wsj.com/articles/jerome-powell-sees-easy-money-policiesstaying-in-place- 11614092400

${ }^{70}$ For 2020 , the official inflation was $1.4 \%$, See, https://www.usinflationcalculator.com/inflation/current-inflation-rates/ . The SGS Alternative CPI, 1980-based gave an inflation of $8 \%$. http://www.shadowstats.com/alternate data/inflation-charts

${ }^{71}$ See, "Biden's \$1.2 trillion infrastructure bill clears the Senate: Here's what's in it for you", https://www.cnet.com/personal-finance/bidens-1-2-trillion-infrastructure-bill-clears-the-senateheres-whats-in-it-for-you/ . Also, "Here are the 17 Republican senators who voted to advance the \$1 trillion infrastructure bill" and helped the Democrats to win next midterm elections, https://www.cnn.com/2021/07/28/politics/republicans-voted-for-infrastructure-packagedebate/index.html . In addition, There is also a second funding package Congress is working on - a $\$ 3.5$ trillion budget reconciliation bill which they are calling it a "human infrastructure" proposal that could expand the redistribution of wealth, "by making education, health care, child care and housing more affordable" according to Senate Majority Leader Chuck Schumer.

72 The "experts" (i.e., Bill Gates) and the "scientists" (i.e., Dr. Anthony Fauci) say that the pandemic will continue in 2022. (Sic). It seems that people will never trust pseudo-experts and pseudoscientists in the future. 
the housing one are very dangerous and their bursting will lead to devastation for our weak economy, due to strange public policies, and the worst, the unbridgeable and enlarging daily division inside the country (unorthodox liberalism, cancel culture, election integrity, control over information, misinformation, election irregularities, climate hysteria, open borders, controlled media, invasion of privacy, violation of medical privacy, "progressive justice reform", group thinking, censorship by the big tech, critical race theory, students indoctrination, "domestic terrorism", mandatory vaccination, vaccine coercion in colleges, authoritarianism, medical misinformation, "human engineering", crime, illegal migration, war on free speech, China's aggressiveness, etc.). (Sic). The future is boded very uncertain, due to public policies and the controlled policy makers.

\subsection{Interest Rates on Deposits}

Another inefficiency is the interest rate on deposits, which are close to zero since December $2008\left(i_{D}=0.05 \%, i_{6 M C D}=0.30 \%\right.$, and $\left.i_{12 M C D}=0.48 \%\right)$ and the real (savings) deposit rate is negative $\left(r_{D}=-4.95 \%\right.$ with the official inflation or $r_{D}=-12.95 \%$ with the SGS inflation), bail in cost. In other words depositors have to pay their banks to keep save the deposits in the banks. But, are these deposits safe? No! We saw 50\% bail in of deposits in Cyprus during the European debt crisis. $^{73}$ (Sic). Many foreign central banks reduced their interest rates on deposits held by banks at them to negative. ${ }^{74}$ With our negative real deposit rates, the Fed was expecting to stimulate the economy by encouraging banks to lend out the deposits they were having and to increase business investments and households spending; but the only effect was the increase in the stock prices (bubbles) and the enormous unfair bail in cost of the depositors. There was no or very little expansionary effect on our GDP growth.

Banks keep all these deposits as reserves and receive IOR by the Fed (bail out cost to taxpayers) or invest them to securities, they do not lend them out because there is no demand for loans and it is also risky. Actually, these negative interest rates became contractionary because banks cut back on lending, too. ${ }^{75}$ It is, actually, a disincentive to save. This policy is not effective in stimulating investment, spending, growth, and employment. Also, it is ethically questionable.

\footnotetext{
73 See, "Bank of Cyprus depositors lose 47.5\%", https://www.usatoday.com/story/money/business/2013/07/29/bank-of-cyprus-depositors-losesavings/2595837/. See also, "Failing banks, bail-ins, and central bank independence: Lessons from Cyprus", https://voxeu.org/article/bank-bail-ins-lessons-cypriot-crisis . In addition, see, Kallianiotis (2018).

${ }^{74}$ The ECB Deposit Facility rate is $-0.50 \%$ since September 18, 2019. See, "Key ECB interest rates",

https://www.ecb.europa.eu/stats/policy_and_exchange_rates/key_ecb_interest_rates/html/index.en. $\underline{\mathrm{html}}$

75 The deposit rates must be positive and $1 \%$ above the expected inflation rate, $\left(i_{D}=\pi^{e}+1 \%\right)$. The current policy is unfair, unethical, contractionary, and risky.
} 


\subsection{Asset-price Bubbles, Financial Crises, and Systemic Risk}

The bubbles from "irrational exuberance" are smaller and less risky for the financial market. For example, these tech-stock or dot-com or internet bubbles in 1990s ${ }^{76}$ caused less trouble. But, big bubbles are created from the enormous liquidity and the greediness ("greed \& fear") of the market participants. These are the reasons that prices of financial assets are getting out of line with fundamentals. At this point the Fed has to stop increasing the money supply by increasing the interest rate, eq. (7). This increase in interest rate must be gradual; otherwise the higher interest rate can cause the bursting of the bubbles. This bubble creation by money supply (correlations and causality) can be seen in Table A1 ${ }^{77}$ The monetary policy has to prevent bubbles because it will be difficult to control them. The Fed does not need to increase federal funds rate to control bubbles because it can harm the economy; but it can increase the margin requirements (i.e., to $r_{m}=90 \%$ ) and reduce the demand for securities. This instrument keeps the stock prices at a normal growth independent from the credit-driven and "irrational exuberance" bubbles. The bubbles can be controlled not only with monetary policy, but with financial market regulations. The low interest rate of the Fed from 2002 to 2005 and from 2008 to present is followed by excessive risk taking. Then, a too easy monetary policy promotes financial instability (bubbles) and it has also generated a liquidity trap, Graph 3.

If we allow banks to decide by themselves (another deregulation) how much they want to hold as reserves, they are going to hold the amount of reserves that minimizes the risk of not having money to give their depositors when they ask for withdrawals. The question is now. Is it good to let the market solve social economic problems rather, than regulators with their law? Banks maximize their objective ignoring the risk because the government will bail them out, as it happened in 2008 that cost to the taxpayers trillions of dollars. The government passaged into U.S. law, on October 3, 2008, a $\$ 700$ billion financial-sector rescue plan that was the latest in the long history of U.S. government bailouts. The 2020 COVID-19 pandemic led to multi-trillion dollar bailouts of both businesses and financing "infrastructures" 78 and individuals in America and similar policies have been taken

\footnotetext{
76 The dotcom bubble, also known as the internet bubble, was a rapid rise in U.S. technology stock equity valuations fueled by investments in internet-based companies during the bull market in the late 1990s. During the dotcom bubble, the value of equity markets grew exponentially, with the technology-dominated NASDAQ index rising from under 1,000 to more than 5,000 between the years 1995 and 2000. In 2001 and through 2002 the bubble burst, with equities entering a bear market. See, https://www.investopedia.com/terms/d/dotcom-bubble.asp See also, "4 Charts That Show This Tech Boom Is No Dot-Com Bubble", https://www.capitalgroup.com/advisor/ca/en/insights/content/articles/tech-boom-no-dot-combubble.html

77 From 2008:12-2015:11, the $\rho_{m, d j i a}=+0.943$ and $m \Rightarrow \operatorname{dji}\left(F=4.033^{* * *}\right)$; and from 2015:12-

2020:12, this correlation was, $\rho_{m, d j i a}=+0.777$.

${ }^{78}$ It was approved by the Senate a $\$ 1.2$ trillion package. (ABC News, 8/10/2021).
} 
across the globe (systemic risk). To date, over $\$ 4$ trillion has been deployed to keep the economy running in the face of this suspicious Chinese pandemic, the Wuhan coronavirus. ${ }^{79}$ How are going to pay all these debts? Who is going to pay, if businesses do not pay taxes? ${ }^{80}$ Regulators (Fed, FDIC, comptroller of the currency, etc.) must concern about the systemic nature of risk in the banking system and should fear about policy, which is not being conducted in an orderly and reliable way, meaning that reserve requirements should exist to control $M B$ and $M^{s},{ }^{81}$ together with higher margin requirements (since 1974, it is $r_{m}=50 \%$ ) ${ }^{82}$ and many other regulations. Moderation and social welfare maximization must be the objective of every policy.

79 See, "US Government Financial Bailouts", https://www.investopedia.com/articles/economics/08/government-financial-bailout.asp . Also, "Emergency Economic Stabilization Act of 2008", https://en.wikipedia.org/wiki/Emergency_Economic_Stabilization_Act_of_2008 . Further, "Here's what's in the $\$ 2$ trillion stimulus package - and what's next",

https://www.politico.com/news/2020/03/25/whats-in-stimulus-package-coronavirus-149282 * A Chinese virologist, Dr. Li-Meng Yan said: "This virus came from a Wuhan Lab and it was intentional." (Fox News, 11/20/2020). A second bill of $\$ 1.9$ trillion was signed by Biden. (Sic). https://www.nbcnews.com/politics/congress/what-s-1-9-trillion-covid-bill-biden-just-signed$\underline{\text { n1260719 }}$. A third infrastructure bill of $\$ 4$ trillion: "Biden reportedly bumps infrastructure price tag to $\$ 4$ trillion, with up to $\$ 3.5$ trillion in tax hikes", https://www.businessinsider.com/bideninfrastructure-bill-package-4-trillion-with-tax-hikes-2021-3

80 The following identified companies were "able to zero out their federal income taxes on $\$ 79$ billion in U.S. pretax income," according to the ITEP report. "Instead of paying \$16.4 billion in taxes, as the new 21 percent corporate tax rate requires, these companies enjoyed a net corporate tax rebate of $\$ 4.3$ billion, blowing a $\$ 20.7$ billion hole in the federal budget last year." To compile the list, ITEP analyzed the 2018 financial filings of the country's largest 560 publicly-held companies. https://publicintegrity.org/inequality-povertyopportunity/taxes/trumps-tax-cuts/you-paid-taxes-these-corporations-didnt/ . See also, "55 Corporations Paid \$0 in Federal Taxes on 2020 Profits". https://itep.org/55-profitable-corporationszero-corporate-tax/. Our tax system is completely unethical and unfair. Here, is another example. A poor person (NJK), who was working part time and made $\$ 11,078$ and received also an unemployment compensation of $\$ 27,737$ for the 2020, paid Federal Income taxes $\$ 3,091$ plus $\$ 349$ State taxes and $\$ 377$ City taxes. A total of $\$ 3,817$ for the tax year 2020 and because he is still unemployed, he borrowed this money to pay taxes. Something is absolute wrong with the IRS and with the politicians in Washington. The business lobbyists bribe and control them and they pay no taxes for the billions of dollars revenue and instead they receive a tax refund. This is the reason that the national debt has reached (8/12/2021) the amount of $\$ 28.633$ trillion. The U.S. total debt as a percent of the GDP is $383.23 \%$. We pay interest on debt of $\$ 3.913$ trillion per annum.

81 The MB was $\$ 5.150$ trillion with May 2020, it became $\$ 5.207$ trillion with January 14,2021 , $\$ 5.248$ trillion on February 23, 2021, \$5.447 trillion on March 23, 2021, and \$6.027 trillion with July 27, 2021. See, https://fred.stlouisfed.org/series/BOGMBASE. The money supply was $\$ 18.115$ trillion, with May 2020, it became $\$ 19.172$ trillion with January 14, 2021, it reached $\$ 19.548$ trillion on January 21, 2021, it became $\$ 19.670$ trillion on March 25, 2021, and lately, July 27, 2021 reached \$20.541 trillion. See, https://fred.stlouisfed.org/series/WM2NS and https://www.federalreserve.gov/releases/h6/current/ .

82 See, "Margin Requirements as a Policy Tool?", https://www.frbsf.org/economicresearch/publications/economic-letter/2000/march/margin-requirements-as-a-policy-tool/ 


\section{The New Monetary Policy and its Social Cost and Benefits}

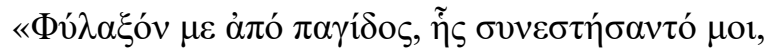

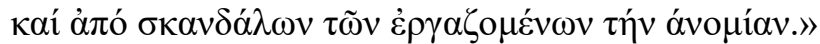

$$
\begin{aligned}
& \Psi \alpha \lambda \mu \text { ó }{ }^{140,}, 9
\end{aligned}
$$

As it was mentioned and it is known to every saver, the deposit rate is closed to zero $\left(i_{D}=0.05 \%\right)$ since December 2008, more than twelve years. This negative real deposit rate is completely unethical and unfair for the depositors, who pay interest to the banks for keeping their deposits (bail in cost). ${ }^{83}$ With an inflation of $\pi=7 \%$ for May 2020, ${ }^{84}$ the real cost of deposits was $r_{D}=-6.95 \%$, which is the amount paid to the banks. ${ }^{85}$ (Sic). Now, the official $\pi=5.4 \%$ and the $r_{D}=-5.35 \%$ and the SGS $\pi=13 \%$, which makes the $r_{D}=-12.95 \%$. Also, these unethical policies have a negative effect on demand for deposits ${ }^{86}$ and force risk-averse individuals to invest in risky financial assets (stocks) seeking to have a positive real return; but banks do not need deposits, they have all these strange excess reserves from the Fed. ${ }^{87}$. Deposits were declining in the U.S. banks until $2018 .^{88}$

83 So far this kind of policy existed only in money (tax) havens, where they were accepted illegal money and were "helping" the depositors to avoid taxes back home, like Switzerland. Now, with our new monetary policies, we have these structures locally; we became Switzerland. See,

file://C:/Users/JK/AppData/Local/Microsoft/Windows/Temporary\%20Internet\%20Files/Content.I E5/QSJRY92C/Corporate-Tax-Dodgers-Report-Final.pdf

${ }^{84}$ See, $S G S$, http://www.shadowstats.com/alternate_data/inflation-charts

85 The interest rate must be positive and above the inflation rate. Even the Bible is talking about

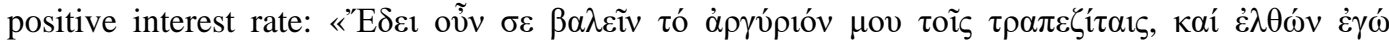

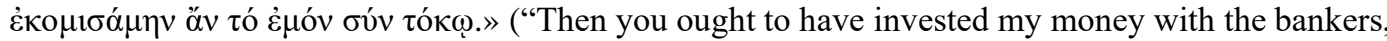
and on my return I would have received what was my own with interest".). Matthew 25: 27.

${ }^{86}$ Depositors demand deposits (deposit accounts), upward sloping positive demand for deposits and banks supply deposits (deposit accounts), downward sloping negative supply of deposits. See, Hadjimichalakis (1982).

87 The Excess Reserves had jumped to \$3.218 trillion with May 2020 and with March 23, 2021 to $\$ 3.346$ trillion. Now (July 27, 2021), the Total Reserves are \$3,848 trillion. See,

https://fred.stlouisfed.org/series/TOTRESNS and

https://fred.stlouisfed.org/series/EXCSRESNS . The required reserves became $\$ 0.000$. This action eliminated reserve requirements for all depository institutions.

https://www.federalreserve.gov/monetarypolicy/reservereq.htm . See also, https://fred.stlouisfed.org/series/REQRESNS . "Recently, the Federal Reserve announced they were reducing the reserve requirement ratio to zero percent across all deposit tiers, effective March 26, 2020. This comes as the COVID-19 pandemic continues to impact much of the way financial institutions both operate and serve their customers."

https://www.eidebailly.com/insights/articles/2020/4/federal-reserve-eliminates-reserverequirements

Thus, now, the total reserves are equal to the excess reserves.

${ }^{88}$ See, Deposits, All Commercial Banks . https://fred.stlouisfed.org/series/H8B1058NCBCAG

See, also, "Weekly National Rates and Rate Caps - Weekly Update",

https://www.fdic.gov/regulations/resources/rates/ 


\subsection{Bail out and Bail in Cost}

Brown (2019) says, "Now, however, the average savings account pays only $0.10 \%$ annually -that's one-tenth of 1\%- and many of the country's biggest banks pay less than that. If you were to put $\$ 5,000$ in a regular Bank of America savings account (paying $0.01 \%$ ) today, in a year you would have collected only 50 cents in interest. That's true for most of us, but banks themselves are earning $2.4 \%$ on their deposits at the Federal Reserve. These deposits, called 'excess reserves', include the reserves the banks got from our deposits, and on which they are paying almost nothing; and unlike with our deposits, there is no $\$ 250,000$ cap on the sums banks can stash at the Fed amassing interest. A whopping $\$ 1.5$ trillion in reserves are now [2019] sitting in Fed reserve accounts. [\$3.218 trillion with May 2020, \$2.877 trillion in October 2020, \$3.154 trillion in February 2021, \$3.346 trillion in March 2021, and $\$ 3.848$ trillion in June 2021]. The Fed rebates its profits to the government after deducting its costs, and interest paid to banks is one of those costs. That means we, the taxpayers, are paying (bail out) $\$ 36$ billion annually to private banks for the privilege of parking their excess reserves at one of the most secure banks in the world - parking them, rather than lending them out." ${ }^{~} 9$ (Sic).

This policy tools (ample reserves and IOR) are, if not anything else, unethical monetary policies going against small savers (investors) and poor taxpayers. Political leaders have no power to regulate the "independent" private central banks, but they can do something for these dishonest ("corrupted") and uncontrolled commercial banks. Central banks' policies are ineffective for the economy, nonpreventable for a new financial crisis, and anti-social for the people. Especially, now, with the suspicious coronavirus; the necessary public policy is a combination of monetary and fair fiscal stimulus policy that the government provided. ${ }^{90}$ The latest monetary policies benefit only large banks, ${ }^{91}$ and generate an enormous social cost, as follows:

With December 2018, we had:

i. The total reserves were:

$R_{R}=\$ 192.209$ billion $+R_{E}=\$ 1,567.691$ billion $=R_{T}=\$ 1,759.9$

billion.

The $i_{I O R}=i_{R F}+0.20 \%=2.37 \%+0.20 \%=2.57 \%$. Actually, it was $2.40 \%$.

Thus, Fed was paying total interest on these reserves:

${ }^{89}$ See, Ellen Brown, "Why Is the Fed Paying So Much Interest to Banks?", https://www.truthdig.com/articles/why-is-the-fed-paying-so-much-interest-to-banks/. See also, "2.4\%, Why Is the Fed Paying So Much Higher Interest Rate to Banks?",

https://www.econmatters.com/2019/04/24-why-is-fed-paying-so-much-higher.html

${ }^{90}$ See, "Fiscal Stimulus Needed to Fight Recessions",

https://www.cbpp.org/research/economy/fiscal-stimulus-needed-to-fight-recessions . But not to make the national debt unsustainable, with some exaggerated and without moderation wastes .

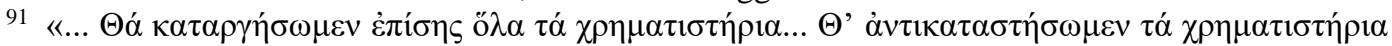

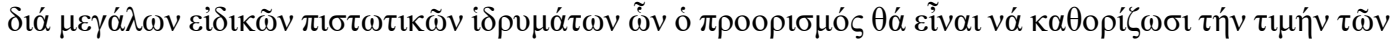

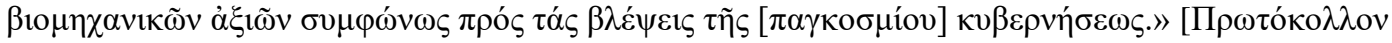
$\left.\mathrm{KA}^{\prime}(\Pi \cdot \Sigma \cdot \Sigma).\right]$. 
$\left(I_{R}\right)=\$ 1,759.9$ billion $\times 2.40 \%=\$ \mathbf{4 2 . 2 3 8}$ billion per annum. This is a

bail out cost that taxpayers are paying. ${ }^{92}$

ii. Total deposits $\left(D_{T}\right)=\$ 12,408.49$ billion. $^{93}$

Deposit rate: $i_{D}=0.05 \%$

Banks were paying an insignificant total interest on deposits

$\left(I_{D}\right)=\$ 12,408.49$ billion $\times 0.05 \%=\$ 6.204$ billion per annum.

iii. The official inflation rate was $(\pi)=2.44 \%$; then,

$r_{D}=i_{D}-\pi=0.05 \%-2.44 \%=-2.39 \%$

Thus, depositors were paying to their banks (bail in):

$\$ 12,408.49 \times(-2.39 \%)=\$ \mathbf{2 9 6 . 5 6 3}$ billion .

The SGS consumer inflation (1980-based) ${ }^{94}$ was $\pi=10 \%$.

The true bail in was: $\$ 12,408.49$ x $(-9.95 \%)=\$ \mathbf{1}, \mathbf{2 3 4} . \mathbf{6 4 5}$ billion p.a.

iv. Banks could offer loans:

$R_{E}+D_{T}=\$ 1,567.691$ billion $+\$ 12,408.49$ billion $=\$ 13,976.181$ billion.

Banks' interest rate was from 3\% (mortgage rate) to $39.99 \%$ (credit cards

with bad credit scores).$^{95}$ The average $i_{C C}=19 \% .{ }^{96}$ Then, the average

${ }^{92}$ Federal Reserve Unfunded interest since 1913 is $\$ 10.772$ trillion and now it is \$527.214 billion. See, https://usdebtclock.org/ . See also, David Walker, "It is time to revise the Federal Reserve's mission", July 16, 2021. https://thehill.com/opinion/finance/563377-it-is-time-to-revise-the-federalreserves-mission

${ }^{93}$ See, https://fred.stlouisfed.org/series/DPSACBW027SBOG

94 See, http://www.shadowstats.com/alternate data/inflation-charts

95 See, https://www.economicshelp.org/blog/6775/debt/total-us-debt-public-private/ See also, https://usdebtclock.org/

${ }^{96} \mathrm{See}$, https://wallethub.com/answers/cc/highest-credit-card-interest-rate-2140660307/.

This unreasonable, unethical, outrageous, and usurious interest rate is charged for the poor people by the unregulated and corrupted banks, as it is mentioned below. Is this a social policy or a deception? The following statement is from one of my graduate students' answer for the question: Is the Risk Premium on our credit cards justifiable? "This is my ethical perspective on Risk Premium on credit cards. While pursuing my undergraduate degree, I worked for one of the most corrupt credit card companies. It is a sub-prime credit card company that preyed on vulnerable people with bad or no credit. The card would be sent out to consumers with $\$ 198$ in processing fees with a $\$ 250$ credit line. People did not read the small printed brochures and people would just activate these cards. People would use these credit cards and not realize that they only had $\$ 52$ to spend. At that point the card would be maxed out and the company began charging over limit fees of $\$ 30$ and an interest rate of $29.99 \%$. Soon this was followed by $\$ 35$ late fees. I do not believe that a high Risk Premium is morally justifiable. I was the representative on the other end of the phone who listened to story after story. For example, an elderly person who purchased a prescription because he/she needed it; a young mother who put gas in her car; a disabled person who did not understand how the credit card worked. These were vulnerable people who were taken advantage of by a greedy, avaricious company. This credit card company did more than mitigate their risks. The company preyed on poor, uneducated people. As a side note, the owner of this company last year received an award for philanthropist of the year. This puts a real spin on what Americans views as value. This is an ethical/moral perspective on the horrors of unchecked free market capitalism." [K. L. (FIN 508) Summer 2013]. Note: In the U.S., the risk premium can reach the level of: $R P=40 \%$ (a regressive tax on the poor). In EU, there is a cap on credit cards risk premium of: $R P=15 \%$. 
loan rate was: $\bar{i}_{L}=(3 \%+19 \%): 2=11 \%$. Banks were having an interest revenue $\left(R_{I}\right)$ of $\$ 13,976.181$ billion $x 11 \%=\$ \mathbf{1 , 5 3 7 . 3 8 0}$ billion p.a. $^{97}$

The conclusion, here, is obvious, the central bank is working for the banks and satisfies only their objectives, which are profitability and liquidity. This monetary policy is against the poor depositors (bail in cost $=\$ 1.235$ trillion p.a. or the "official" bail in cost $=\$ 296.563$ billion) and against the poor taxpayers (bail out cost $=\$ 42.238$ billion p.a.); a pure anti-social policy and at the same time it had created enormous bubbles in the stock market (a hidden new global crisis, which found an excuse to burst, the Wuhan coronavirus). ${ }^{98}$ With this unethical monetary policy, the deposit and saving rate was falling (Figure 4) and the personal consumption expenditures were increasing (Figure 5). Thus, the household debt is going up. ${ }^{99}$

With February 2020, we had:

i. The total reserves were: $\$ 1,726.9$ billion.

The $i_{I O R}=i_{R F}+0.20 \%=1.52 \%+0.20 \%=1.72 \%$. But, it was $1.60 \%$.

Thus, the Fed was paying total interest on these reserves

$\left(I_{R}\right)=\$ 1,726.9$ billion $\mathrm{x} 1.60 \%=\$ 27.630$ billion per annum. This was the bail out cost that taxpayers were paying.

ii. Total deposits $\left(D_{T}\right)=\$ 13,341.785$ billion.

$i_{D}=0.05 \%$

Banks were paying an insignificant total interest on deposits

$\left(I_{D}\right)=\$ 13,341.785$ billion $\times 0.05 \%=\$ 6.671$ billion per annum.

iii. The official inflation rate was $(\pi)=0.30 \%$; then,

$r_{D}=i_{D}-\pi=0.05 \%-0.30 \%=-0.25 \%$.

Thus, depositors were paying to their banks

(bail in): $\$ 13,341.785 \times(-0.25 \%)=\$ 33.354$ billion per annum.

The SGS consumer inflation (1980-based) ${ }^{100}$ was $\pi=7 \%$.

The true bail in was: $\$ 13,341.785 \times(-6.95 \%)=\$ 927.254$ billion p.a.

iv. Banks could offer loans:

$R_{E}+D_{T}=\$ 1,726.9$ billion $+\$ 13,341.785$ billion $=\$ 15,068.685$ billion .

\footnotetext{
97 See, Kallianiotis (2020a).

98 The DJIA reached 29,551.42 (2/12/2020) and with coronavirus negative effects on health and economy, it fell to $18,591.93(3 / 23 / 2020)$, it lost $10,959.49$ points $(-37.09 \%)$. I had read somewhere a few years ago that: "we (the economic elites) will abolish the stock exchanges and we will create large financial institutions..." (Sic).

99 The total personal debt $(2 / 27 / 2021)$ was $\$ 21.137$ trillion $\mathrm{x} 11 \%=\$ 2.325$ trillion annual interest on personal debt. See, https://usdebtclock.org/ . Actually, the average person is paying taxes (plus the unethical property taxes), interest, and insurance premium; the rest of his income is consumed. For this reason his saving is negative (dissaving, borrowing).

100 See, SGS. http://www.shadowstats.com/alternate data/inflation-charts
} 
Banks' interest rate was from $2.49 \%$ (mortgage rate) to $35.99 \%$ (credit cards with bad credit scores). ${ }^{101}$ The average $i_{C C}=19.24 \% .{ }^{102}$ Then, the average loan rate was: $\bar{i}_{L}=(2.49 \%+19.24 \%): 2=10.865 \%$.

Banks were having an interest revenue $\left(R_{I}\right)$ of $\$ 15,068.685$ billion $\times 10.865 \%=\$ \mathbf{1 , 6 3 7 . 2 1 3}$ billion p.a.

Thus, the lack of ethics in monetary policy was continued and taxpayers and depositors were ripped off endlessly. The higher the $i_{I O R}$ and the higher the inflation $\pi$, the higher will be the bail out and the bail in cost.

With December 2020, we had:

i. The total reserves were: $R_{T}=3,135$ billion.

The $i_{I O R}=i_{R F}+0.20 \%=0.09 \%+0.20 \%=0.29 \%$. But, it was $i_{I O R}=0.10 \%$.

Thus, Fed was paying total interest on these reserves

$\left(I_{R}\right)=\$ 3,135$ billion $\times 0.10 \%=\$ \mathbf{3 . 1 3 5}$ billion per annum. This is a bail out cost that taxpayers are paying.

ii. Total deposits $\left(D_{T}\right)=\$ 16,084.745$ billion. ${ }^{103}$

$i_{D}=0.05 \%$

Banks were paying an insignificant total interest on deposits

$\left(I_{D}\right)=\$ 16,084.745$ billion $\mathrm{x} 0.05 \%=\$ \mathbf{8 . 0 4 2}$ billion per annum.

iii. The official inflation rate was

$(\pi)=1.4 \%$; then, $r_{D}=i_{D}-\pi=0.05 \%-1.4 \%=-1.35 \%$

Thus, depositors were paying to their banks (bail in):

$\$ 16,084.745 \times(-1.35 \%)=\$ 217.144$ billion .

The SGS consumer inflation (1980-based) ${ }^{104}$ was $\pi=9 \%$.

The true bail in was: $\$ 16,084.745 \times(-8.95 \%)=\$ \mathbf{1} \mathbf{4 3 9 . 5 8 5}$ billion p.a.

iv. Banks could offer loans:

$R_{E}+D_{T}=\$ 3,135$ billion $+\$ 16,084.745$ billion $=\$ 19,219.745$ billion.

Banks' interest rate was from $2.49 \%$ (mortgage rate) to $35.99 \%$ (credit cards with bad credit scores). The average $i_{C C}=19.24 \%$. Then, the average loan rate was: $\bar{i}_{L}=(2.49 \%+19.24 \%): 2=10.865 \%$.

Banks were having an interest revenue

$\left(R_{I}\right)$ of $\$ 19,219.745$ billion $\times 10.865 \%=\$ \mathbf{2 , 0 8 8 . 2 2 5}$ billion p.a.

101 See, https://www.economicshelp.org/blog/6775/debt/total-us-debt-public-private/ See also, https://usdebtclock.org/

102 See, https://wallethub.com/answers/cc/highest-credit-card-interest-rate-2140660307/

103 See, Economagic.com

104 See, http://www.shadowstats.com/alternate data/inflation-charts 
With July 2021, we have:

i. The total reserves were: $R_{T}=3,848.1$ billion.

The $i_{I O R}=i_{R F}+0.20 \%=0.05 \%+0.20 \%=0.25 \%$. But, it was $i_{I O R}=0.15 \%$.

Thus, Fed is paying total interest on these reserves $\left(I_{R}\right)=\$ 3,848.1$ billion $\mathrm{x} 0.15 \%=\$ \mathbf{5 . 7 7 2}$ billion per annum. This is a bail out cost that taxpayers are paying.

ii. Total deposits $\left(D_{T}\right)=\$ 17,278.4535$ billion. $^{105}$

$i_{D}=0.05 \%$

Banks were paying an insignificant total interest on deposits

$\left(I_{D}\right)=\$ 17,278.4535$ billion $\mathrm{x} 0.05 \%=\$ \mathbf{8 . 6 3 9}$ billion per annum.

iii. The official inflation rate is

$(\pi)=5.4 \%$; then, $r_{D}=i_{D}-\pi=0.05 \%-5.4 \%=-5.35 \%$

Thus, depositors were paying to their banks (bail in):

$\$ 17,278.4535 \times(-5.35 \%)=\$ \mathbf{9 2 4 . 3 9 7}$ billion.

The SGS consumer inflation (1980-based) ${ }^{106}$ was $\pi=13 \%$.

The true bail in was: $\$ 17,278.4535 \times(-12.95 \%)=\mathbf{\$ 2 , 2 3 7 . 5 6 0}$ billion p.a.

iv. Banks could offer loans:

$R_{E}+D_{T}=\$ 3,848.1$ billion $+\$ 17,278.4535$ billion $=\$ 21,126.553$ billion .

Banks' interest rate was from $2.428 \%$ (mortgage rate) to $35.99 \%$ (credit cards with bad credit scores). The average $i_{C C}=19.24 \%$. Then, the average loan rate was: $\bar{i}_{L}=(2.428 \%+19.24 \%): 2=10.834 \%$.

Banks were having an interest revenue $\left(R_{I}\right)$ of $\$ 21,126.553$ billion $\mathrm{x}$ $10.834 \%=\$ \mathbf{2 , 2 8 8 . 8 5 1}$ billion p.a.

The Fed's current balance sheet is so huge (it was $\$ 4,175.850$ billion with January 15, 2020; with June 10, 2020, it had reached $\$ 7,168.936$ billion, with December 2 , 2020 , it was $\$ 7,222.414$ billion, with February 10, 2021, it is $\$ 7,442.225$ billion, with March 22, 2021, it was \$7,719.622 billion and now, July 19, 2021, it was $\$ 8,240.530$ billion) ${ }^{107}$ that with the new announced policy rate decrease again (March 15, 2020), it could possibly generate surprising results and higher market risk. Some improvement to the bail out cost (taxpayers), due to low interest rate on reserves might exist, but deterioration to the bail in cost (depositors) from the high inflation has been attained. The level of banks' capital is another factor that must be considered by the regulators (central bank, FDIC, comptroller of the currency, etc.). A low capital level is increasing the risk of the banks and consequently, the cost of financial crises (by bailing them out in case of a financial crisis); so the banks' capital affects the real economy. Risk-averse consumers prefer higher capital levels

\footnotetext{
105 See, Deposits, All Commercial Banks. https://fred.stlouisfed.org/series/DPSACBW027SBOG

106 See, http://www.shadowstats.com/alternate data/inflation-charts

107 See, https://www.federalreserve.gov/monetarypolicy/bst_recenttrends.htm and https://fred.stlouisfed.org/series/WALCL
} 
because it increases the financial stability in the economy and the world. The taxpayers cannot bailout the corrupted and deregulated financial institutions in case of a new bank crisis, as it happened in 2008 because it is completely unfair and unethical. ${ }^{108}$ Firestone, Lorenc, and Ranish (2019), by evaluating the economic costs and benefits of bank capital in the U.S., found that the optimal capital ratio is from just over $13 \%$ to $26 \%{ }^{109}$ The current average capital ratio is $12.5 \%$ for the U.S. banks, which is relatively low.

Proudly with uninhibited arrogance and very often, lately, in the U.S. and in Europe, the central bankers remind to politicians (pseudo-leaders) and to the public that they are independent (From whom? From the citizens? From the country's social objectives? Who has given to them this right?). (Sic). But, their objective must be the social wellbeing of the citizens.

The former heads of the Federal Reserve made their case, on August 5, 2019, for the central bank to remain independent and free from short-term political pressures; ${ }^{110}$ an implicit rebuttal to President Trump's repeated criticism of this private institution, the Fed. ${ }^{111}$ All four former still-living Fed chairs -Paul Volcker, ${ }^{112}$ Alan Greenspan, Ben Bernanke and Janet Yellen ${ }^{113}$ - consigned an op$\mathrm{ed}^{114}$ underlining their belief that the central bank and its leader should be allowed

108 The total lost household wealth at that time was between $\$ 19.2$ and $\$ 22$ trillion. See, https://www.pbs.org/wgbh/frontline/article/how-much-did-the-financial-crisis-cost/ and https://www.huffpost.com/entry/financial-crisis-cost-gao_n_2687553 . See also, "I helped bail out the banks, Congress needs to oversee the stimulus now", https://thehill.com/blogs/congressblog/politics/496307-i-helped-bail-out-the-banks-congress-needs-to-oversee-the . In addition, See, Kallianiotis (2021a and b).

109 See, Firestone, Lorenc, and Ranish (2019). See also, Farla-e-Castro (2019). Further, "What's a Countercyclical Capital Buffer?", https://fredblog.stlouisfed.org/2019/09/whats-a-countercyclicalcapital-buffer/

${ }_{110}$ But, President Woodrow Wilson had said that the U.S. lost control of its financial system by allowing its Central Bank to be independent of the government (private): "I am a most unhappy man. I have unwittingly ruined my country. A great industrial nation is controlled by its system of credit. Our system of credit is concentrated. The growth of the nation, therefore, and all our activities are in the hands of a few men. We have come to be one of the worst ruled, one of the most completely controlled and dominated Governments in the civilized world -- no longer a Government by free opinion, no longer a Government by conviction and the vote of the majority, but a Government by the opinion and duress of a small group of dominant men." [Woodrow Wilson President of the United States (1913-1921)]. What can we say 105 years later, where individual liberties and freedom have been lost? With the 2020 election irregularities, President Trump said: "We are like third world country; this election was a fraud." (Fox News, 11/26/2020). The current political, social, and economic situation has killed Americans' hope for ever.

111 If at that time, President Woodrow Wilson had said these words for the Fed; then, we can imagine what he would have said if he was the President, today, facing this many-sided war from the liberals, globalists, the media, "experts", and foreign nations.

112 Paul Volcker passed away on December 8, 2019. https://www.sgtreport.com/2019/12/formerfed-chairman-paul-volcker-passes-away-at-92/

113 Joe Biden appointed Janet Yellen as Treasury Secretary. (ABC News, 11/23/2020).

114 See, "America Needs an Independent Fed", The economy functions best when the central bank is free of short-term political pressures, The Wall Street Journal,

https://www.wsj.com/articles/america-needs-an-independent-fed-11565045308?mod=article inline 
to serve without political pressures or "the threat of removal or demotion... for political reasons". "It is critical to preserve the Federal Reserve's ability to make decisions based on the best interests of the nation, not the interests of a small group of politicians," the former central bankers wrote. ${ }^{115}$ (Sic).

This rhetoric is good, but unbelievable and unreasonable because what we see so far, it is that Fed's policies are made only for the speculative financial market, its participants, and for the uncontrolled financial institutions. Their effects on the real economy are insignificant and many times ineffective by creating bubbles and accomplishing the next recession. If the central bank's decisions were based on the best interest of the nation, it would have a policy to prevent financial crises and recessions and not to try to cure them, after their creation. ${ }^{116}$ Federal Reserve Chairman Jerome Powell gave his most forceful warning yet (on August 23, 2019) about the risks to the U.S. economy from escalating trade tensions and the limits to the central bank's ability to cushion any fallout. (Sic). The trade deficit has to become zero $(T A \cong 0)^{117}$ that is one of Fed's objectives, so the country can become self-sufficient and not dependent on foreign production, which is very risky, as we saw with the medical supplies and the medicine during the coronavirus pandemic, which are coming from China. China is in control of our economy and it tries to control our politics, too, and it is successful with the current administration. China is also moving forward for global economic and military domination.

115 See, "Former Fed Leaders Plea for Central Bank's Political Independence". https://www.wsj.com/articles/former-fed-leaders-plea-for-central-banks-political-independence11565051192 . Unfortunately, "Our money is not our money. We rent it. We have rented it since 1781 when the Bank of North America gained control of the money supply in the closing days of the Revolutionary War. We need to own our money as citizens responsible for both the government and the economy of the United States." See, Bob Blain, The Root of United States Public and Private Debt, 2017. Also, "Permit me to issue and control the money supply of a nation and I care not who makes its laws." (Mayer Amschel Rothschild, 1744-1812). Further, "The privilege of creating and issuing money is not only the supreme prerogative of Government, but it is the Government's greatest creative opportunity." (Abraham Lincoln, 1862). In addition, "Until the control of the issue of currency and credit is restored to government and recognized as its most conspicuous and sacred responsibility, all talks of the sovereignty of Parliament and of democracy is idle and futile." (William Lyon Mackenzie King, Canadian Prime Minister, 1874-1950). Furthermore, the issuance of Executive Order 11110 (June 4, 1963) was an effort by Kennedy to transfer power from the Federal Reserve to the United States Department of the Treasury by replacing Federal Reserve Notes with silver certificates. These are some small indications of what is going on in our world, which are all contributions to social cost and suppression of human liberties and rights by the global

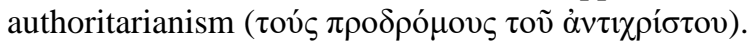

116 See, Kallianiotis (2020c).

117 The U.S. trade deficit was $\$ 678.7$ billion in 2020 ; with China the trade deficit is $\$ 310.8$ billion. See, Kimberly Amadeo, "What Is the Current U.S. Trade Deficit?", https://www.thebalance.com/u$\underline{\text { s-trade-deficit-causes-effects-trade-partners-3306276 }}$ 
Powell signaled that the central bank would follow its rate cut of July $312019 .{ }^{118}$ On January 29, 2020, the FOMC decided to keep the federal funds at the same level; but the coronavirus pandemic forced the Fed to reduce the target rate back to zero ${ }^{119}$ (March 16, 2020).

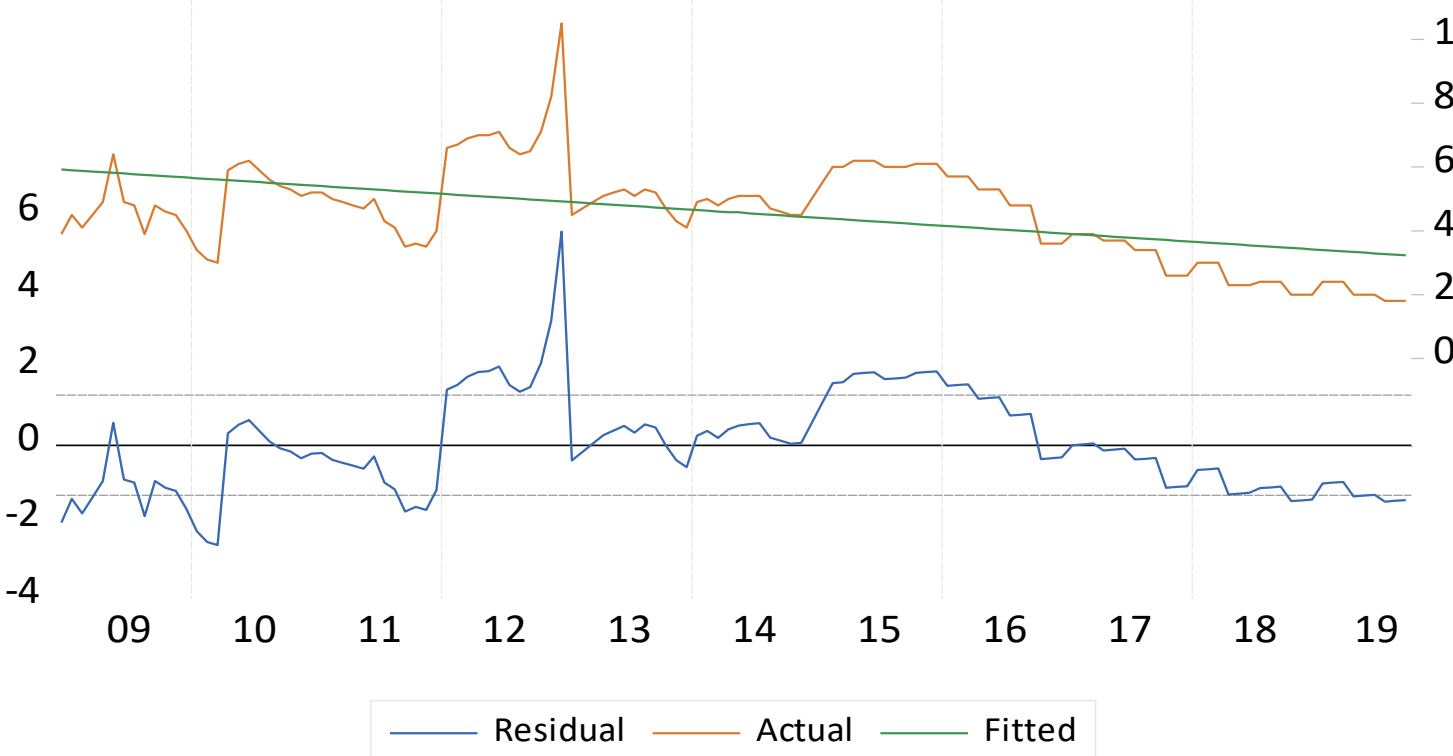

Figure 4. U.S. Personal Saving Rate

Note: The Regression of the time trend of personal saving rate is:

$$
\begin{aligned}
& \begin{aligned}
& U S P S R=8.423^{\text {***** }}-0.021^{\text {***** }} t \\
&(0.574) \quad(0.003)
\end{aligned} \\
& R^{2}=0.267, \quad S E R=1.306, \quad F=46.674, \quad D-W=0.340, \quad N=130
\end{aligned}
$$

\footnotetext{
118 See, "Fed Cuts Rates by a Quarter Point in Precautionary Move", Central bankers say move protects against risks posed by muted inflation, global growth concerns. https://www.wsj.com/articles/fed-cuts-rates-by-a-quarter-point-ends-portfolio-runoff$11564596200 ? \mathrm{mod}=$ article inline\&mod=article inline\&mod=article inline. See also, https://www.wsj.com/articles/powell-says-fed-prepared-to-provide-stimulus-if-a-slowdown-hits-us-economy-11566568965 . Fed Chairman Jerome Powell 's press conference on September 18, 2019 carried a subtle message for President Trump: If you are worried about an economic slowdown, find a way to cool down the trade war. See, "Analysis: Powell's Subtle Messaging to Trump on Trade Fight". The globalist Fed chairman mentioned trade 20 times at his news conference on Wednesday (9/18/2019). https://www.wsj.com/articles/analysis-powells-subtlemessaging-to-trump-on-trade-fight-11568971800 . On January 15, 2020, the U.S. and China signed a Trade Agreement. See, The Wall Street Journal, January 16, 2020, pp. A1, A7, B1, and B12.

119 Thus, from $\bar{i}_{F F}=1.50 \%-1.75 \%$ back to $\bar{i}_{F F}=0.00 \%-0.25 \%$. See, https://www.federalreserve.gov/newsevents/pressreleases/monetary20200129a1.htm
} 


\subsection{Monetary Policy Rules and their Benefits}

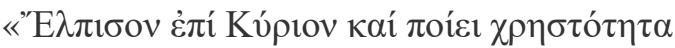

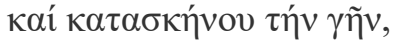

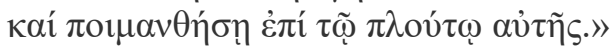

$\Psi \alpha \lambda \mu o ́ \varsigma 36,3$

We can use different monetary policy rules (interest rate reaction functions) to test the efficiency and effectiveness of the target interest rate $\left(\bar{i}_{F F}\right)$ and of course, to see if the level of the federal funds rate is optimal. The objective of the Fed is stabilization of output (maximum employment) and prices (inflation target, $\pi_{t}=$ $2 \%$ ), hoping to stimulate consumption and investment.

Central bank's behavior (reaction to inflation and output-employment) can be presented with an interest rate reaction function, eq. (3), as follows:

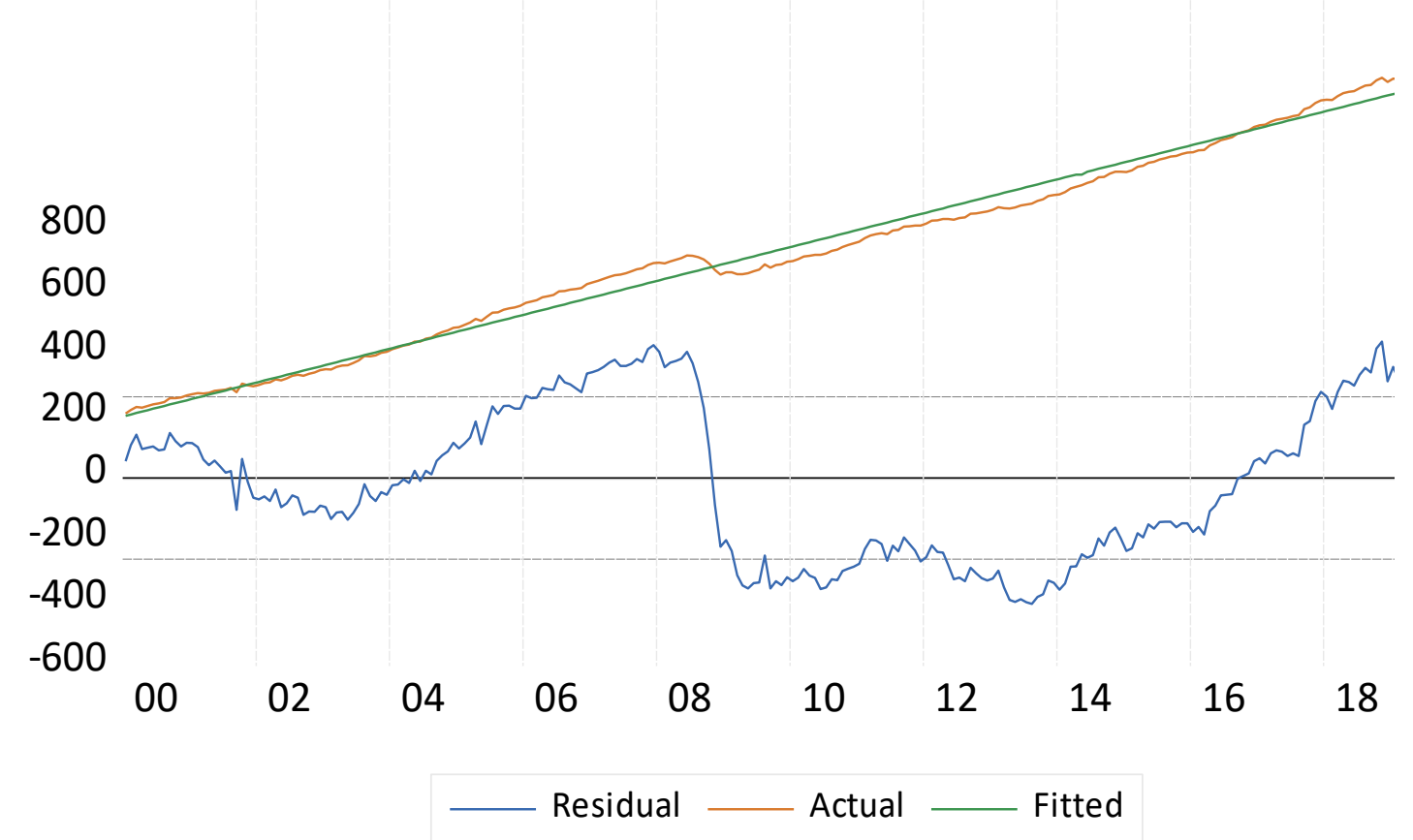

Figure 5: U.S. Personal Consumption Expenditure and its L-T Trend

Note: The Regression for the personal consumption time trend is:

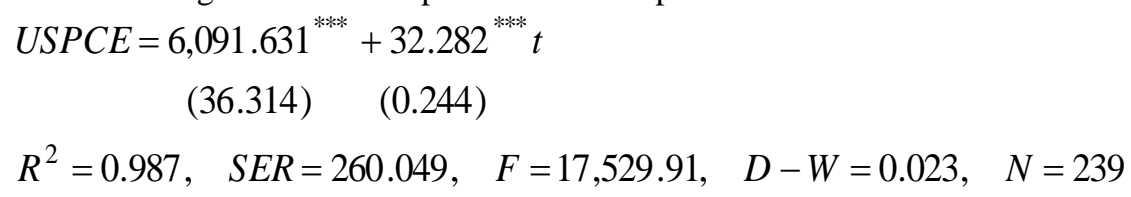




$$
\bar{i}_{F F_{t}}=\rho \bar{i}_{F F_{t-1}}+(1-\rho)\left(\pi_{t}+r_{t}^{*}\right)+\alpha_{\pi}\left(\pi_{t}-\pi_{t}^{*}\right)-\alpha_{u}\left(u_{t}-u_{t}^{N}\right)
$$

where, $\quad \bar{i}_{F F_{t}}=$ the target federal funds rate, $\pi_{t}=$ the rate of inflation as measured by the GDP deflator, $\pi_{t}^{*}=$ the desired rate of inflation, ${ }^{120} r_{t}^{*}=$ the assumed equilibrium real interest rate, $u_{t}=$ the unemployment rate, $u_{t}^{N}=$ the natural level of unemployment, and $\rho=$ the weight put on the past federal funds rate setting.

We can run a regression of eq. (3), which is presented in eq. (4). The target interest rate will follow the changes in inflation and unemployment based on the coefficients estimated in eq. (4). This interest rate measured by the interest rate reaction function must be the target federal funds rate:

$$
\bar{i}_{F F_{t}}=\alpha_{0}+\alpha_{1} \bar{i}_{F F_{t-1}}+\alpha_{2} \pi_{t}+\alpha_{3} u_{t}^{G A P}+\alpha_{4} u_{t-1}^{G A P}+\varepsilon_{t}
$$

where, $u_{t}^{G A P}=u_{t}-u_{t}^{N}$.

Using monthly data for the U.S. economy (1954:08-2021:01), we have:

$$
\begin{aligned}
& \bar{i}_{t}=0.072^{*}+0.984^{* * * *} \bar{i}_{t-1}+0.015^{* * * *} \pi_{t}-0.147^{* * * *} u_{t}^{G A P}+0.121^{* * * *} u_{t-1}^{G A P} \\
& \begin{array}{lllll}
(0.034) & (0.006) & (0.005) & (0.041) & (0.041)
\end{array} \\
& R^{2}=0.982, \quad S E R=0.487, \quad F=10,743.25, \quad D-W=1.306, \quad N=798
\end{aligned}
$$

The size of the partial adjustment, coefficient $\alpha_{1}$, which is $0.984^{* * *}$ provides direct evidence that the observed degree of persistence in federal funds rates is greater than the one that can be attributed to systematic policy responses to persistent inflation and unemployment (output) fluctuations. The coefficients of regression show that the federal funds rate must respond significantly to an increase in inflation $\left(\alpha_{2}=0.015^{* * *}\right)$, but less aggressively to induce an increase in real rates and a tightening monetary policy. The federal funds rate must respond sufficiently aggressively to an increase in unemployment $\left(\alpha_{3}=-0.147^{* * * *}\right)$ to induce a reduction in interest rate and an effective easing monetary policy.

120 The Fed ultimately stated explicitly that its target was a $2 \%$ per year increase in the raw personal consumption expenditures deflator. See, Williamson (2014, p. 112). Here, we forecast the inflation, as follows:

$$
\begin{aligned}
& \pi_{t}^{e}=\pi_{t}^{*}=3.476^{* * * *}+1.289^{* * * * *} \pi_{t-1}-0.301^{* * * * *} \pi_{t-2}-0.908^{* * * *} \varepsilon_{t-1} \\
& \begin{array}{llll}
(0.836) & (0.034) \quad(0.031) & (0.022)
\end{array} \\
& R^{2}=0.348, S E R=3.364, F=113.360, D-W=2.001, N=854, R M S E=3.355977
\end{aligned}
$$


From 2008:12 to 2015:11 (period of zero federal funds rate), we had,

$$
\begin{gathered}
\bar{i}_{t}=0.036^{\text {*** }}+0.573^{\text {**** }} \bar{i}_{t-1}+0.001 \pi_{t}+0.015 u_{t}^{G A P}-0.011 u_{t-1}^{\text {GAP }} \\
(0.009) \quad(0.065) \quad(0.001) \quad(0.015) \quad(0.015) \\
R^{2}=0.622, \quad S E R=0.025, \quad F=32,512, \quad D-W=1.079, \quad N=84
\end{gathered}
$$

From 2015:12 up to 2020:02 (new regime: $0.25 \% \leq i_{F F} \leq 2.50 \%$ ), ${ }^{121}$ the results are,

$$
\begin{aligned}
& \bar{i}_{t}=0.055+0.984^{* * * *} \bar{i}_{t-1}-0.004 \pi_{t}+0.110 u_{t}^{\text {GAP }}-0.084 u_{t-1}^{G A P} \\
& (0.076)(0.046) \quad(0.006) \quad(0.116) \quad(0.117) \\
& R^{2}=0.985, \quad S E R=0.095, \quad F=742.510, \quad D-W=1.208, \quad N=51
\end{aligned}
$$

During the latest two monetary policy regimes from 2008 to 2020 , the coefficients of regressions are insignificant, showing that the federal funds rate does not respond significantly to an increase in inflation to induce an increase in real rates and a tightening monetary policy. Also, the federal funds rate does not respond sufficiently aggressively to an increase in unemployment to induce a reduction in interest rate and an effective easing monetary policy. Thus, these monetary policies the last twelve (12) years have nothing to do with the real sector (Main Street) of the economy and its objectives (inflation, growth, and unemployment). The only effects were on interest rate (negative real returns) and on financial markets (a new enormous bubble). ${ }^{122}$ And a third worse effect, the bail in of the banks (depositors are paying interest on their deposits to the banks for "safe keeping their deposits") and the bail out of the banks (taxpayers are paying the interest on reserves of the banks). (Sic). Thus, there is an ethical issue, ${ }^{123}$ here, and the social benefits are very limited or imaginary for this monetary policy.

Further, the Taylor rule is a specific case of eq. (3); it puts $\rho=0$ and we get by substituting, from the original equation, the logarithm of GDP with the unemployment rate, the following equation:

$$
\bar{i}_{F F_{t}}=\pi_{t}+r_{t}^{*}+\alpha_{\pi}\left(\pi_{t}-\pi_{t}^{*}\right)-\alpha_{u}\left(u_{t}-u_{t}^{N}\right)
$$

\footnotetext{
121 Since March 17, 2020, the federal funds rate went back to: $0.00 \% \leq i_{F F} \leq 0.25 \%$.

122 See, Kallianiotis and Petsas (2020, Table 1).

123 These monetary policies are unfair, wrong, anti-social, and against the poor citizens of the country. And after all of these deceptions, from the global financial crisis, came the Chinese plague, the coronavirus. The deduction from all these crises is very simple; we need a strong fiscal and trade policy that have to be in favor of the poor people, a "pro-American" public policy and an effective monetary one.
} 
Taylor (1993) proposed an $\alpha_{\pi}=0.5$ and $\alpha_{u}=-0.5 .{ }^{124}$ The rule "recommends" a high interest rate (a "tight" monetary policy) when inflation is above its target, in order to reduce inflationary pressure, as we have now, and a low interest rate ("easy" monetary policy) when the unemployment rate is above its natural level to stimulate production, output, and employment. ${ }^{125}$

Then, by using the Bullard rule, ${ }^{126}$ we have:

$$
\bar{i}_{F F_{t}}=\rho i_{F F_{t-1}}+(1-\rho)\left[r_{t}^{*}+\pi^{*}+\phi_{\pi}\left(\pi_{t}-2 \%\right)+\phi_{q}\left(u_{t}-4 \%\right)\right]
$$

In addition, financial market plays a major role in market oriented economies and its optimal growth has a positive effect on investors' and consumers' confidence. The opposite happens, if growth is artificially enormous (abnormal bubbles). Kallianiotis (2019c) rule is an expansion of eq. (5) by using an extra term, the growth of the financial market $\left(g_{D J A_{4}}\right)$, as follows,

$$
\bar{i}_{F F_{t}}=\pi_{t}+r_{t}^{*}+\alpha_{\pi}\left(\pi_{t}-\pi_{t}^{*}\right)-\alpha_{u}\left(u_{t}-u_{t}^{N}\right)+\alpha_{D J I A}\left(g_{D J I A_{t}}-g_{D J I A_{t}}^{*}\right)
$$

where, $g_{D J I A_{t}}=$ the actual growth of the DJIA index, $g_{D J I A_{t}}^{*}=$ the optimal (the bubble prevention) growth of the DJIA

$$
\begin{aligned}
& \left(g_{D J I A_{4}}^{*} \leq 7 \% \cong i_{10 Y T B}+5 \% \text { or } H R P \cong 8.7 \%\right),{ }^{127} \text { and } \alpha_{\pi}=0.25, \\
& \alpha_{u}=-0.50,{ }^{128} \alpha_{D J I A}=0.25
\end{aligned}
$$

The results, from: (1) Taylor's rule [eq. (5)], (2) Bullard's rule [eq. (6)], and (3) Kallianiotis' rule [eq. (7)], are as follows. ${ }^{129}$

124 There is a Phillips curve in our economy. See, Kallianiotis (2021a).

125 If the economy has a high inflation and it is in a recession (with high unemployment), we must have a target interest rate: $\bar{i}_{F F}=5.4 \%+1 \%+0.5(5.4 \%-2 \%)-0.5(5.9 \%-4 \%)=7.15 \%$. This should have been the federal funds rate in June 2021, but it was between $0.00 \%$ and $0.25 \%$, which was very low; and it was ineffective, it did not improve growth and did not reduce inflation and unemployment.

126 See, St. Louis Fed President, James Bullard (2018a and b) rule.

127 For the Historic Risk Premium (HRP), see, Ross, Westerfield, Jaffe, and Jordan (2016).

128 The coefficient of unemployment is higher because full employment is the most important objective of every policy. Citizens of a country need work (employment), certainty (zero risk), confidence for the financial market (no bubbles and enormous declines), and low inflation (the true cost of production of a good). And above all, they need a democratic system and not something like the current indescribable one.

${ }^{129}$ For more details, see, Kallianiotis and Petsas (2020). 
(1) Taylor's Rule:

The target federal funds rate was between $(0.00 \%-0.25 \%)$ for the period 2008:12 to 2015:11 (Zero Interest Rate Regime). ${ }^{130}$ Thus, $i_{F F}$ must have been:

$i_{F F}=1.586 \%+1 \%+0.5(1.586 \%-2 \%)-0.5(7.838 \%-4 \%)=0.46 \%$; but, it was

between $0 \%$ and $0.25 \%$ (average $\bar{i}_{F F}^{\text {eff }}=0.129 \%$ ), which was low.

From 2015:12 to 2018:12 (New Regime) the $i_{F F}$ must have been:

$i_{F F}=1.906 \%+1 \%+0.5(1.906 \%-2 \%)-0.5(4.389 \%-4 \%)=2.6645 \%$; but, it was

between $0.25 \%$ and $2.50 \%$ (average $\bar{i}_{F F}^{e f f}=1.054 \%$ ), which was too low.

Thus, Taylor's rule recommends higher federal funds rate.

(2) The Bullard rule, now, gives:

For the ZIRR (2008:12-2015:11) the $i_{F F}$ must have been:

$i_{F F}=0.85(0.25 \%)+0.15[1 \%+2 \%+1.5(1.586 \%-2 \%)+1(7.838 \%-4 \%)=1.14505 \%$;

but it was $0.129 \%$, very low.

For the NR (2015:12-2018:12) the $i_{F F}$ must have been:

(i) When $\bar{i}_{F F}=0.50 \%$ :

$$
i_{F F}=0.85(0.25 \%)+0.15[1 \%+2 \%+1.5(1.906 \%)+1(4.389 \%-4 \%)=0.6997 \%
$$

which was low.

(ii) When $\bar{i}_{F F}=0.75 \%$ :

$$
i_{F F}=0.85(0.50 \%)+0.15[1 \%+2 \%+1.5(1.906 \%-2 \%)+1(4.389 \%-4 \%)=0.9122 \%
$$

which was low.

(iii) When $\bar{i}_{F F}=2.50 \%$ :

$$
i_{F F}=0.85(2.25 \%)+0.15[1 \%+2 \%+1.5(1.906 \%-2 \%)+1(4.389 \%-4 \%)=2.3997 \%
$$

which was relatively good.

(iv) When $\bar{i}_{F F}=1.75 \%$ :

$$
i_{F F}=0.85(2.00 \%)+0.15[1 \%+2 \%+1.5(1.906 \%-2 \%)+1(4.389 \%-4 \%)]=2.4122 \%
$$

which was very low $(1.75 \%)$.

Thus, even Bullard's rule shows that the target federal funds rate is relatively low.

\footnotetext{
${ }^{130}$ For federal funds target rate, see, http://www.fedprimerate.com/fedfundsrate/federal funds rate history.htm
} 
(3) Lastly, the Kallianiotis rule, ${ }^{131}$ which gives the following results:

For the ZIRR (2008:12-2015:11) the $i_{F F}$ must have been:

$i_{F F}=1.586 \%+1 \%+0.25(1.586 \%-2 \%)-0.50(7.838 \%-4 \%)+0.25(9.952 \%-7 \%)=1.5095 \%$ which was very low $(0.00 \%-0.25 \%)$.

For the NR (2015:12-2018:12) the $i_{F F}$ must have been:

$i_{F F}=1.906 \%+1 \%+0.25(1.906 \%-2 \%)-0.50(4.389 \%-4 \%)+0.25(10.78 \%-7 \%)=3.633 \%$ which was very low $(1.75 \%)$.

The results show that the target rates of our central bank (Fed) are very low. The empirical results and all the tests and rules reveal that these monetary policies do not promote social welfare, because its social benefits are less than its social cost. Measuring the correlation $(\rho)$ and testing the causality $(\Rightarrow)$ between the instruments $\left(i_{F F_{t}}, M B\right.$, and $\left.M^{s}\right)$ and the objective variables ( DJIA, GDP, $i_{10 Y T B}, P$, and $u$ ), the results are given in Table A1. From 2008:12-2015:11, a reduction in $i_{F F}$ reduces $i_{10 Y T B}$ and reduces unemployment $(u)$. Also, an increase in $M B$ increases DJIA and GDP, reduces $i_{10 Y T B}$, increases prices and reduces unemployment. Further, an increase in $M^{s}$ increases DJIA and GDP, reduces $i_{10 Y T B}$, increases prices and reduces unemployment. From 2015:12-2020:12, the $i_{F F}$ causes $G D P$, prices $(P)$, and unemployment $(u)$. The increase in $M B$ increases $G D P$, reduces $i_{10 ү т в}$ and increases unemployment. The increase in $M^{s}$ increases $G D P$ and increases unemployment.

Now, testing the effects of the instruments on the objective variables $(C, I, T A, e$, and $G D P$ ), we have the results that are showing in Table A2. The results show from 2008:12 to 2015:11 that the reduction in $i_{F F_{t}}$ had increased consumption $(C)$. The increase of $M B$ has improved $C, I, T A, G D P$, and the dollar was appreciating. The increase of $M^{s}$ has increased $I, T A$, production and the value of the dollar. From 2015:12 to 2020:12, the increase of $i_{F F_{t}}$ has improved investment and growth of $G D P$. The increase of $M B$ has negative effects on $C, I, T A, G D P$, and on the dollar value. The increase of $M^{s}$ increases $C, I$, and $G D P$, but no other effects.

131 Kallianiotis rue with June 2021 gives: (1) With official data, the target federal funds rate $\left(\bar{i}_{F F}\right)$ must have been:

$i_{F F}=5.4 \%+1 \%+0.25(5.4 \%-2 \%)-0.50(5.9 \%-4 \%)+0.25(18.22 \%-8.7 \%)=8.68 \%$

(2) With SGS data, the $\bar{i}_{F F}$ should have been:

$i_{F F}=13 \%+1 \%+0.25(13 \%-2 \%)-0.50(25.8 \%-4 \%)+0.25(18.22 \%-8.7 \%)=8.23 \%$ 


\section{Policy Implications of the New Instruments}

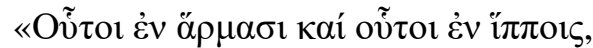

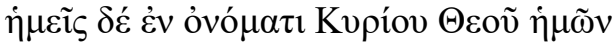

$\mu \varepsilon \gamma \alpha \lambda v v \theta \eta \sigma o ́ \mu \varepsilon \theta \alpha . »$ $\Psi \alpha \lambda \mu o ́ \varsigma 19,8$

We can use the Equation of Exchange, eq. (8), to measure the velocity of money (V) and the effect of money supply $(\mathrm{M})$ on the price level $(\mathrm{P})$ and on the nominal output $(Y=Q P)$.

$$
M V=Q P
$$

where, $M=$ money in circulation, $V=$ the velocity of circulation (the number of times a dollar changes hands annually), $Q=$ the real GDP, $P=$ the price level, Y $=$ the nominal GDP.

From eq. (8), we receive the velocity,

$$
V=\frac{Q P}{M}
$$

Then, the velocity is variable over time because $Q, P$, and $M$ are changeable by monetary policy, Graph $4 .^{132}$

132 The Velocity of M2 is even lower. In 2021:Q1 it was 1.122 and in 2021:Q2 became 1.120 (July 29, 2021). See, https://fred.stlouisfed.org/series/M2V 


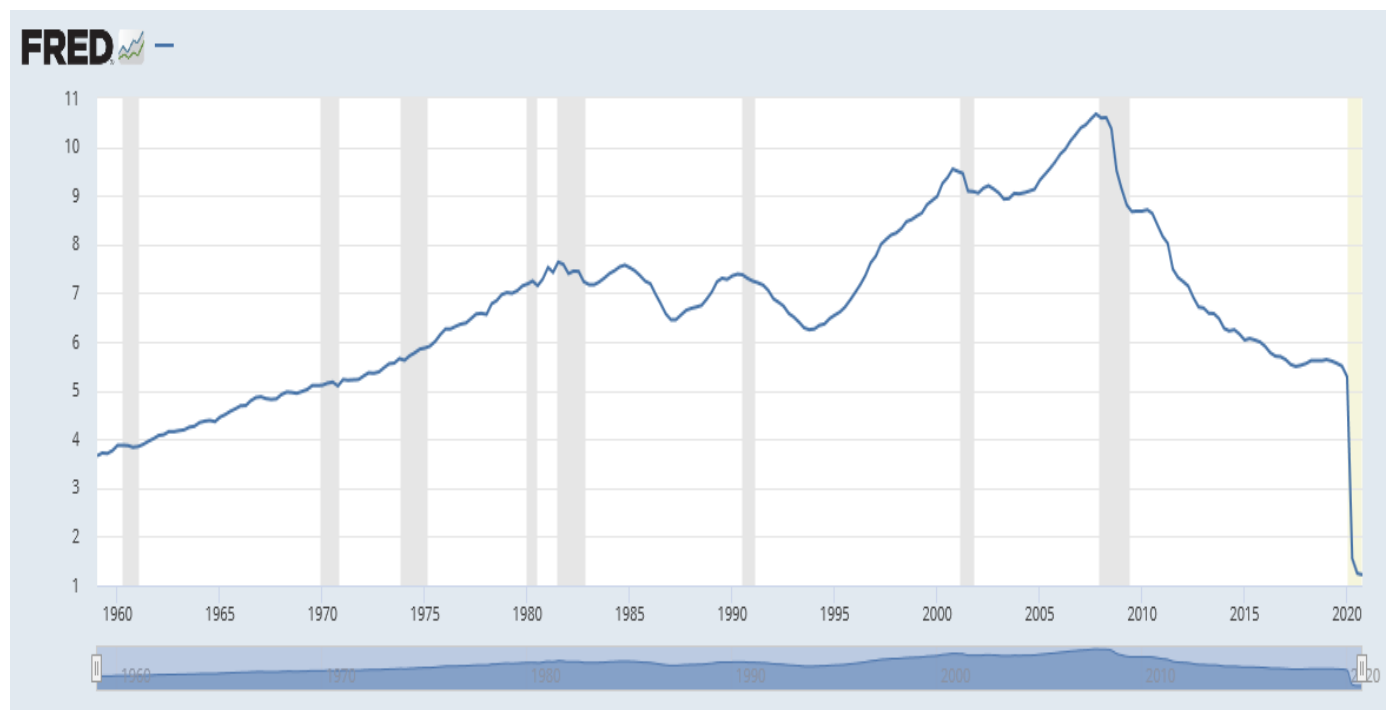

\section{Graph 4: Velocity of Money Stock (M1)}

Note: In 2007:Q4, the velocity was 10.678, in 2019:Q4 had fallen to 5.5, and in 2020:Q2 became 3.872 , which means that the income was increasing more than $10 \mathrm{x}$, after 2019 fell to $5 \mathrm{x}$, and after 2020 fell below $4 \mathrm{x}$, which reduces the income. In 2020:Q1 was 5.285, 2020:Q2 $=1.555,2020: \mathrm{Q} 3$ $=1.247$, in $2020: \mathrm{Q} 4$ fell to 1.221 , in $2021: \mathrm{Q} 1$ was 1.198 , and in 2021:Q2 became 1.187. (Updated: July 29, 2021).

Source: https://fred.stlouisfed.org/series/M1V

The largest the velocity, the faster the money circulates and more income is generated because every time the money changes hands, it becomes income for another person. Thus, the easy money policy $\left(0.00 \%<i_{F F}<0.50 \%\right)$ from 2008 to $2017^{133}$ and the new monetary policy instruments (IOR, $Q E, R_{R}=0, i_{O N R R P}$, and ample reserves) did not affect the real economy; it just lowered the velocity of money, ${ }_{134}$ increased the market risk (bubbles), augmented the expectations for a creeping double digit inflation, and generated enormous negative real returns. People did not spend their money, but the Fed was subsidizing the financial sector by creating a new bubble, which was burst with the "innovative" Chinese coronavirus (its biological WWIII), which was exploited to the extreme by the Illuminati. The federal funds went back to zero (March 15, 2020), ${ }^{135}$ and the same cycle will be repeated. This liquidity trap (zero interest rate), Graph 3, does not allow the Fed to influence monetary policy, because it cannot lower the interest rate further to stimulate the economy.

133 "Federal Funds Target Range (FFR)", See, https://fred.stlouisfed.org/series/DFEDTARU For the "Effective Federal Funds Rate (EFFR)", see, https://fred.stlouisfed.org/series/EFFR

134 See, Kallianiotis (2021a).

135 See, https://apps.newyorkfed.org/markets/autorates/fed\%20funds . Also, see, https://fred.stlouisfed.org/series/DFEDTARU 
Also, it has become a real trap for the risk-averse depositors that have a closed to zero deposit rate since 2008. ${ }^{136}$ Monetary policy has become ineffective. ${ }^{137}$ Interest rate must be consistently above zero in our non-ideal (imperfect) world (because, $\pi^{e}>0$ and Risk $\left.>0\right) .{ }^{138}$ Fiscal policy can be mostly effective, if the government is a democratic, impartial, and not a very corrupted one, because it is independent from interest rate. But, today, these types of governments do not exist. Also, trade policy (exchange rate, tariffs, import taxes, quotas, etc.) is inevitably necessary because is making the domestic economy self-sufficient and independent from the foreign economies. ${ }^{139}$

$$
P=\frac{M V}{Q}
$$

The enormous money supply $(M 2)^{140}$ increases the prices $(P)$, eqs. (8) and (10), and real wages $(w / P)$ are falling, but the workers have no choice and continue to work and they are happy that they are employed or they receive the generous unemployment compensation from the government. ${ }^{141}$ The debt is going up and people prefer to stay home, instead of going to work. The money supply ( $M 2)$ increases nominal income $(Y)$, eq. (11), which is actually an increase in prices and

136 With an inflation for February 2020, $\pi=2.3 \%$, the depositor, instead of receiving interest, he was paying to his bank $\left(r_{D}=i_{D}-\pi=0.05 \%-2.3 \%=-2.25 \%\right.$ p.a. to keep his deposits.

https://tradingeconomics.com/united-states/inflation-cpi. Now, $r_{D}=0.05 \%-13 \%=-12.95 \%$ (SGS inflation).

137 See, Kallianiotis (2019a, b, c, 2020a, b, c, and d, and 2021a).

138 Because, $i=r^{*}+\pi^{e}+R P$; where, $\mathrm{i}=$ nominal rate of interest, $\mathrm{r}^{*}=$ real risk-free rate of interest, $\pi^{\mathrm{e}}=$ expected inflation, and $\mathrm{RP}=$ risk premium.

139 "The economics profession [with their artificial theories, heroic assumptions, and wrong philosophies (believes, $\dot{\eta} \pi \lambda \alpha \dot{v} \eta \tau \tilde{\omega} v \psi \varepsilon v \delta o-\varepsilon \dot{\pi} \epsilon \sigma \tau \eta \mu o ́ v \omega v)]$ bears the responsibility that the public, the media, and politicians are ill informed about real world economics." See, Komlos (2019b, p. 14). ${ }^{140}$ Money supply ( $M 2$ ) from $\$ 7,459.6$ billion (1/14/2008) became $\$ 17,234.8$ billion (4/30/2020), a growth of $131.042 \%$ (10.697\% p.a.), and reached $\$ 18,318.2$ billion (7/20/2020). See, https://fred.stlouisfed.org/series/M2 , on (3/25/2021), it was $\$ 19,669.8$ billion, and now, $(7 / 27 / 2021)$, it is $\$ 20,541.2$. Thus, $\pi^{\mathrm{e}}=10 \%$.

${ }^{141}$ A $\$ 1.2$ trillion "infrastructure" (redistribution) bill was approved by the senate. Nineteen Republicans joined Democrats in voting for the bipartisan infrastructure deal on Tuesday (8/10/2021). See, https://www.cnn.com/2021/08/10/politics/republican-senators-votedinfrastructure-bill/index.html. Also,"Senate Democrats unveiled new details about the $\$ 3.5$ trillion climate and anti-poverty package they hope to pass this fal"l. Here's what to know about the sweeping plan. See, https://www.wsj.com/articles/senate-democrats-release-outline-of-3-5trillion-antipoverty-climate-plan-11628513109 . Further, "Democrats reach deal on \$3.5T price tag for infrastructure (reconciliation) bill". https://thehill.com/policy/transportation/562889democrats-reach-deal-on-35-trillion-price-tag-for-infrastructure-bill Also, the IRS sent out the first child-tax-credit payments. "The Expanded Child Tax Credit Is Here. Here's What You Need To Know", See, https://www.npr.org/2021/07/15/1016122095/the-expanded-child-tax-credit-ishere-heres-what-you-need-to-know 
not on real output. This is the "money illusion". Firms sell their products to higher prices and make more profits, so they expand production and hire more workers at the same nominal wage (w), but during this period, the U.S. workers prefer to stay home and get the welfare benefits from the socialist government. (Sic) A Phillips curve $^{142}$ exists in the short run. Workers cannot ask for higher nominal wages in our globalized and open borders world because firms start hiring illegal immigrants at very low wages or they do outsourcing. ${ }^{143}$

$$
Y=Q P=M V
$$

Economists have different philosophical views about the policy used to stimulate the economy. ${ }^{144}$ Thus, politicians choose as advisors the economists, who suit their ideology. Everything is subjective. Markets, businesses, and institutions exist and governments are elected to serve the people and to contribute to social welfare and not to care only for their interest, otherwise we do not need them. We need an ideal and humane economic system with zero unemployment, zero inflation, zero trade deficits, zero government deficit, zero households deficit; public policies that make no even a single individual worse off of what he was before and a maximization of social welfare for every citizen, based on person's merits and abilities. But if these conditions do not exist; the markets, the institutions, and the policy makers are not efficient and need to be regulated. But, who is going to regulate regulators?

Fed reduced the federal funds rate (on December 16, 2008) to $0.25 \%$ (quantitative easing) ${ }^{145}$ to affect positively (increase) the money supply. Really, the money supply has increased drastically ( $M B$ from $\$ 850.8$ billion in September 2007 became $\$ 4,149.505$ billion in September 2014; in January 2021, it reached $\$ 5,247.900$ billion, at the end of March 2021, it was $\$ 5,446.900$ billion, and on June 22,2021 , it was $\$ 6,041.900$ ) and continues to be magnified. ${ }^{146}$ At a given price level, it was expected the aggregate demand $(A D)$ to rise. More money in the

\footnotetext{
142 See, Kallianiotis (2021c) for the Phillips curve and its estimation. See also, Ihrig, Peneva, and Wolla (2021),

143 "AT\&T CEO Randall Stephenson promised to create "7,000 good jobs for the middle class" after Trump's tax cut was passed, yet the company has been laying off thousands of workers and shipping those jobs overseas to India, China and other countries where workers can be paid less than $\$ 2$ [ $\$ 0.50$ in China and $\$ 0.10$ in India] an hour. This is what a rigged economy is all about." See, https://www.techdirt.com/articles/20191211/10503943556/att-said-trump-tax-cuts-would-createthousands-jobs-instead-atts-laying-off-thousands.shtml

${ }^{144}$ A Nobel laureate was giving a speech in our University and he said: "I teach free trade to my students, but I am against free trade, I prefer trade control (tariffs) for the benefits of our country". 145 Fed Funds Rate History with Its Highs, Lows, and Charts: How the Benchmark Has Changed Through History, https://www.thebalance.com/fed-funds-rate-history-highs-lows-3306135 . See, also, https://www.federalreserve.gov/monetarypolicy/openmarket.htm

146 A growth of the MB by $\$ 3,298.705$ billion or $387.718 \%$ (55.39\% per annum). Then, if inflation is a monetary phenomenon (according to Monetarist School), we must have a double digits inflation, as actually it is, now.

https://fred.stlouisfed.org/series/BOGMBASE/
} 
economy and closed to zero interest rate was expected to equate money supply with money demand. This lower interest rate (cost of capital) and the ample reserves could stimulate more investment and consumption. More investment and consumption require a higher level of GDP for spending balance. All these should shift aggregate demand to the right and the economy will improve. But, the aggregate demand did not rise because people are unemployed and their debts are enormous. The cost of capital (loans' rate) went down and the banks had all this liquidity generated by the Fed, but businesses and people did not borrow; there was no demand for their products (lockdowns) ${ }^{147}$ and people did not have the confidence and the required qualifications to borrow and they did not want more debt in the middle of the biggest constructed crisis in human history. Then, individuals' demand fell and firms' investment declined, too, ${ }^{148}$ because in an economy demand creates supply $(A D \Rightarrow A S)$ and not the opposite. Actually, consumption (Figure 5) and investment fell and aggregate demand decreased drastically, which affected negatively production, output, and employment. ${ }^{149}$ But, banks are receiving interest (IOR) ${ }^{150}$ from the Fed (paid by taxpayers) on their excess reserves (non-disposable funds) and on the required reserves (before their abolition). ${ }^{151}$ These expansions benefit only the high income people through financial markets (Figure 6).

147 “32 Bankruptcy Filings Chalked Up to COVID-19”. See, https://www.kiplinger.com/investing/603194/bankruptcy-filings-chalked-up-to-covid-19-2021 Also, "55\% of businesses closed on Yelp have shut down for good during the coronavirus pandemic". See, https://www.marketwatch.com/story/41-of-businesses-listed-on-yelp-have-closedfor-good-during-the-pandemic-2020-06-25 . Further, "Corporate bankruptcies slow for now, could pick up later in 2021, experts say", see, https://www.spglobal.com/marketintelligence/en/news-insights/latest-newsheadlines/corporate-bankruptcies-slow-for-now-could-pick-up-later-in-2021-experts-say-64100726

148 See, Gross Private Domestic Investment (GPDI), FRED, https://fred.stlouisfed.org/series/GPDI 149 See, Real Gross Domestic Product (RGDP), FRED, https://fred.stlouisfed.org/graph/?g=f1cZ

150 See, Kallianiotis (2019a, b, c and 2020b and c).

151 Required reserves were abolished on March 26, 2020. See, Kallianiotis (2020c). See, also, https://www.federalreserve.gov/monetarypolicy/reservereq.htm 


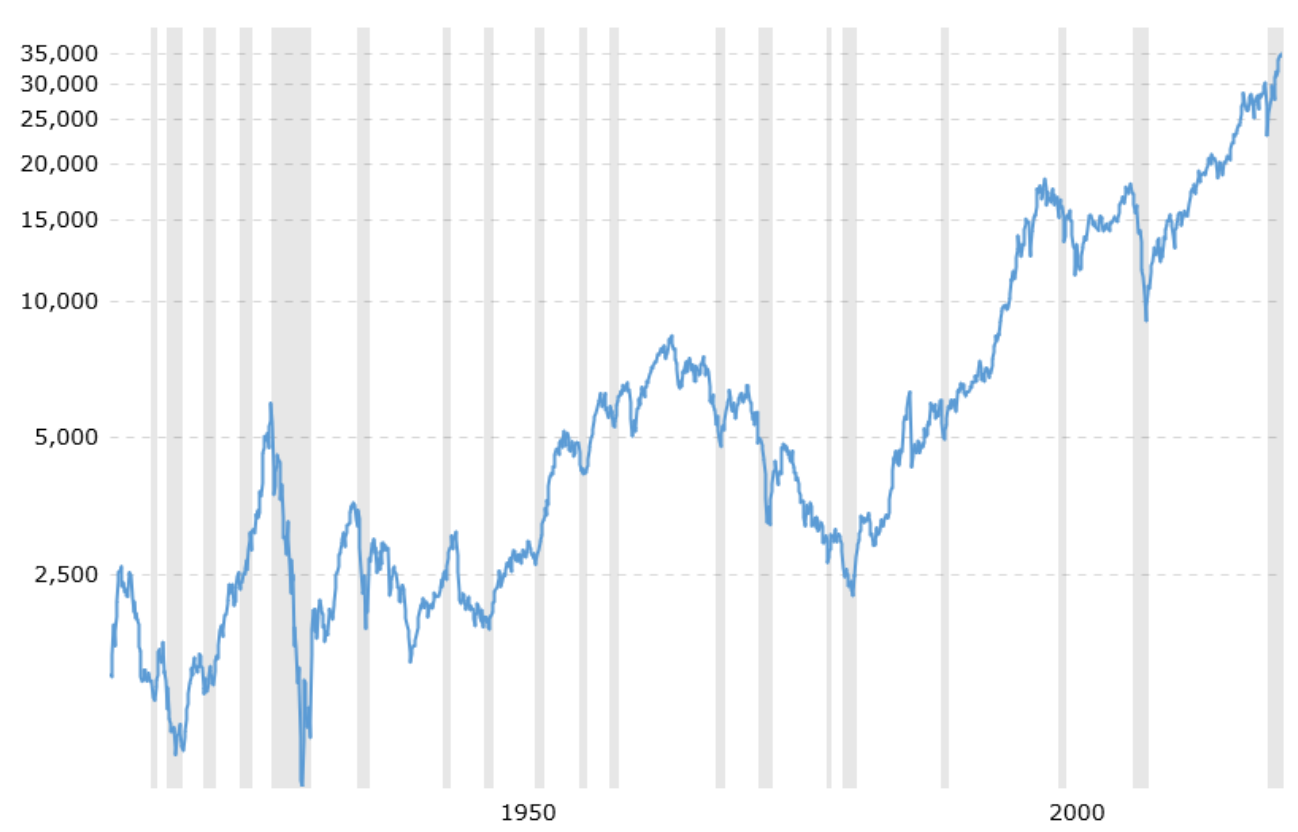

Figure 6: The DJIA Index

Note: Dow Jones - DJIA - 100 Year Historical Chart

Source: Macrotrends https://www.macrotrends.net/1319/dow-jones-100-year-historical-chart

The Great Recession (2008) $)^{152}$ vs the Great Destruction (2020) ${ }^{153}$ followed the subprime mortgage bubble and the stock market bubble with a substantial decline in income, increases in unemployment, a rise in foreclosures, and maximized the suffering of the U.S. people. The investment was cut and the aggregate demand declined. This was a deep recession. In September 2008, the big in size and risk investment banks disappeared and the poor taxpayers bailed out the Wall Street, but there were again neglected the true structural problems of the U.S. economy. The

152 The causes of the latest global financial crisis (2008) are: (1) Greenspan's Ideology, (2) The Financial Innovations, (3) The Rise of the Shadow Banking System, (4) The Neglect of Systemic Risk, (5) Groupthink rendered Greenspan's view politically correct, (6) The Dot-Com Bubble, (7) The lowering of Interest Rates, (8) Credit Rating Agencies, (9) Excessive Faith in Quantitative Finance, (10) Endemic Trade Deficits, (11) Easy Credit, (12) Banks Lowered Underwriting Standards, (13) Expansion of Subprime Lending, (14) Predatory Lending, (15) Bubble in House Prices, (16) The Illusion of Tranquility was Deceptive, (17) Deregulation, (18) High Debt Burden, (19) Financialization, (20) Herd Mentality, (21) Mispricing of Risk, (22) Out of control Leverage, (23) Globalization, (24) Moral Hazard, (25) Lack of Historical Perspective, (26) Hubris was ubiquitous, (27) Culture, (28) Inequality of Income, (29) Corporate Governance, (30) Revolving Door (executive in finance were appointed to government position), and (31) Media (fake news). See, John Komlos, Foundations of Real-World Economics, Second Edition, Routledge, 2019, pp. 243-252.

${ }^{153}$ See, Kallianiotis (2020d). 
Fed and the Treasury tried to help the economy, but the country continued to have the same structural problems, the immense trade deficit, the foreign dependence, the national debt and private debts, the deteriorating infrastructure, part time and half time work, students debt, the cost of illegal immigrants, the green revolution, and a government that could not overcome the lobbies, but it introduced a new doctrine to control the free speech, the elusive "politically correct", and to finance and maintain so many unnecessary conflicts and wars around the world. The Obama administration did not make any structural changes, except of deepening the division among people and institutionalizing liberalism; the Trump administration tried for four years to revise and restructure this economic setback and affliction, but he was confronted with all the implausible means that the establishment can invent, from impeachments to the Chinese coronavirus; with the current administration, all signs for improvement are so far negative.

This recent crisis of 2020, with the suspicious coronavirus, the health problems, the hundred thousands of deaths, the extended lockdown of businesses, the shutdown of the economy, the stay-at-home orders, it destroyed the small businesses and will help only the monopolists; it affected negatively Universities and education in general. It led the civil liberties at risk and had unexpected consequences of this ongoing isolation (drugs, alcohol, psychological problems, violence, divorces, and crimes). Then, it "came" (they allowed) the civil unrest, the manipulation of the public opinion by the liberal media, the riots, violent, lootings, chaos, lawlessness, destruction, division, and the election irregularities. Further, some experimental vaccines appeared in a few months, which have increased the uncertainty and deaths by generating new variants, and have raised many ethical questions among people. ${ }^{154}$ Unfortunately, this new crisis it seems as the worst in human history, ${ }^{155}$ a global Great Destruction ${ }^{156}$ and it is impossible the current monetary policy to generate soon any recovery.

Furthermore, another proof, showing the control (by the "economic elites") of the private central banks, is coming from U.K. The globalists of the Bank of England were against the Brexit; which means they were against the referendum of the people (they act anti-democratically) and tried to terrorize the British citizens and

154 These vaccines were supposed to help us get back to normal, but they do not do anything. Dr.

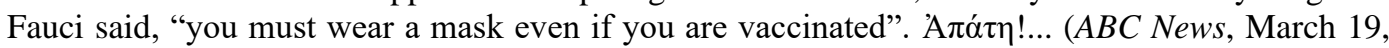
2021).

155 And in the U.S. this crisis has political ramifications; it is manipulated and utilized by the liberals to go against the conservatives. Now, it comes to my mind what one of my professors in Microeconomics was telling us (his students) 42 years ago: "A politician has only one interest, to be reelected, nothing else; he does not care for you, for the economy, for the country or anything else." At that time, I did not believed him because I was very young. Today, I see that he was absolutely right. See, Kallianiotis (2019b and c, 2020a and c, and 2021).

156 European banks are using the pandemic to make changes investors have wanted for years: slash jobs, shut branches and force customers online. See, Patricia Kowsmann and Margot Patrick, "European Banks Use Pandemic to Clean House", February 14, 2021. https://www.wsj.com/articles/european-banks-use-pandemic-to-clean-house-

$\underline{11613298601 ? \mathrm{mod}=\mathrm{md} \text { usstk news }}$ 
to keep them inside the EU by saying: "if they will leave the EU, there will be a global disaster". ${ }^{157}$ How can we trust the controlled central bankers, who do not believe in democracy and do not respect the will of the citizens? U.K. had a referendum and they voted in favor of leaving the oppressive EU. ${ }^{158}$ The best solution for the society will be to make all these central banks public institutions; so they will work only for the people, for their nations, and for their wellbeing and not terrorizing them and control (influence) their investment and economic decisions, their destiny, and their economic welfare. ${ }^{159}$

157 TV News ANTENNA, 8/1/2019. See also, "Brexit: Day arrives for the UK to finally leave the EU after 47 years", https://www.9news.com.au/world/brexit-news-day-finally-arrives-uk-leaveseu-live-updates-blog/57b16099-f01b-4b61-b6e7-fdb076d07671. This is actually a success (a win) of democracy!.. See, https://www.bing.com/search?q=wsj+brexit+arrives $\% 2 \mathrm{c}+\mathrm{a}+$ watershed+moment+for+britain + and+ the+eu\&FORM=AWRE . See also, the controlled media with their misinformation and lies,

"Support for Brexit is collapsing as poll finds big majority of British people want to be in the EU", https://www.businessinsider.com/brexit-poll-most-british-people-want-to-rejoin-eu-2020-6

158 This was the United Kingdom European Union membership referendum; also known as the EU referendum, the European referendum and the Brexit referendum, which took place on June 23, 2016 in the UK and Gibraltar to ask the electorate if the country should remain a member of, or leave the EU, under the provisions of the European Union Referendum Act 2015 and also the Political Parties, Elections and Referendums Act 2000. The referendum resulted in $51.9 \%$ of votes being in favor of leaving the EU (17,410,742 votes). The government of that time had promised to implement the result, but the country was still in the union for over 4 more years, until December 31, 2020. Greece had also a referendum on July 5, 2015 and $61.31 \%$ vote NO to EU memoranda, but EU made it YES. Greece has to leave the Euro-zone and become independent from its controlled "protectors", otherwise the country has no future.

https://en.wikipedia.org/wiki/2015_Greek_bailout_referendum. This liberal EU is actually a controlled trap and not a union. See, Kallianiotis (2018).

159 Unfortunately, lately, globalists' and ecumenists' "religion" is Mother Earth, the Ecology (global warming); but last and current year's winter disappointed them with temperatures $-50 \% \mathrm{~F}$ and heavy snow storms all over the north hemisphere. The rest of our "objectives" are all under their control even before the French Revolution (1789). See, Kallianiotis (2017b). Also see, https://www.jacobinmag.com/2015/07/french-revolution-bastille-day-guide-jacobins-terrorbonaparte/. 


\section{Conclusions}

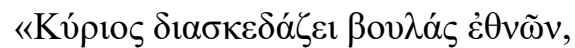

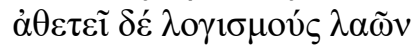

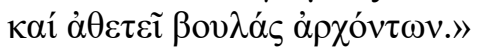

$$
\begin{aligned}
& \Psi \alpha \lambda \mu \text { ó } 32,10
\end{aligned}
$$

After 2008, the Fed has changed the way it implements monetary policy. It has, now, two overnight interest rates: (1) Interest rate paid on banks' reserves $\left(i_{I O R}\right)$ and (2) Interest rate on the overnight reverse repurchase agreements $\left(i_{\text {ONRRP }}\right)$. In December 2008, the target rate range between $0.00 \%$ and $0.25 \% .{ }^{160}$ Between 2008 and 2014, the Fed purchased a sizable amount of long-term securities (government securities and mortgage-backed securities). The reserves in the banking system went from $\$ 44.9$ billion (August 2007) to $\$ 2.842$ trillion (August 2014). ${ }^{161}$ Then, the reserves from limited became "ample" (plentiful, vi $\pi \varepsilon \rho \mu \varepsilon \gamma \varepsilon \dot{\theta} \theta \eta$, vं $\varepsilon \dot{\varepsilon} \rho \varepsilon \tau \rho \alpha$ ) and now (July 27, 2021), they are \$3.848 trillion. Also, the Fed implemented new monetary policy tools. The most significant was interest on reserves ( IOR ). Congress gave to Fed the authority to pay IOR in $2006,{ }^{162}$ with starting date in 2011, but it started earlier in October 2008. Interest on reserves applies to both required (IORR) and excess reserves (IOER). This IOR is a bail out cost paying by taxpayers (consequently, an unfair and unethical "innovation"), which cost billion of dollar per annum.

Lastly, the Fed has changed the way it implements monetary policy since 2008 . The FOMC sets a particular federal funds target range (i.e., $\bar{i}_{F F}=0.00 \%-0.25 \%$ ) that is reflected in current and expected short-term interest rates. As it was mentioned above, this change in tools reflects a change in what the Fed calls its "implementation regime." This is a change in the Fed's policy implementation framework, which it is a policy with ample reserves. The Fed uses, now, its administered rates, which are the interest on reserve, IOR rate $\left(i_{I O R}\right)$ and the overnight reverse repurchase agreement, ON RRP rate $\left(i_{O N R R P}\right)$ to influence the federal funds rate $\left(i_{F F}\right)$.

This Fed's "innovation" (the ample reserves) has kept the deposit rate closed to zero $\left(i_{D}=0.05 \%\right)$ because banks' supply of deposits has been reduced (shifts to the left)

\footnotetext{
160 The Fed also implemented a number of credit and liquidity programs, which are mentioned in Kallianiotis (2021c, section 2.2), early on in the Financial Crisis to support financial institutions and foster improved conditions in financial markets. These special programs expired or were closed to expire after some time.

161 See, https://fred.stlouisfed.org/series/TOTRESNS

162 This "innovation" took place under President George W. Bush and Ben S. Bernanke, who was sworn in on February 1, 2006, as chairman and a member of the Board of Governors of the Federal Reserve System. He also chaired the Federal Open Market Committee, the System's principal monetary policymaking body.
} 
and the real deposit rate negative for twelve years ${ }^{163}$ and has discouraged saving and intermediation by risk-averse middle-income people. This is an unethical bail in cost for the depositors, which is in trillion of dollars per annum.

The objective of monetary policy is to smooth the large fluctuations of the business cycle. There are debates rages on whether monetary policy can smooth business cycles $^{164}$ or not. A central conjecture of Keynesian Economics ${ }^{165}$ is that the central bank can stimulate aggregate demand $(A D)$ in the short run, because a significant number of prices in the economy are fixed in the short run (real money is increasing) and firms will produce as many goods and services as are demanded. In the long run, however, money is neutral (real money stays the same because prices are going up), as in the neoclassical model. ${ }^{166}$ There is also the Austrian School of Economics, which includes different arguments, but most economists fall into either the Keynesian or neoclassical school of thoughts on this issue. The central bank can use policy rules to make federal funds rate optimal, which will satisfy the monetary policy's objectives (price stability, maximum employment, and stability of the financial markets). These can be attained with a mixed policy (monetary and fiscal). Further, many economists unconditionally support free trade, deregulation, globalization, liberalism, radicalism, enormous debts, deficits, and trade account deficits, zero interest rate, low business taxes, unfair competition, anti-nationalism, open borders, market efficiency, government control, no consumer protection, etc. without any regard to those who are devastated by the foreign competition and the domestic anti-social policies and the worst, no concern for the future generations. Economists, as social scientists, must be humanists with very high social values and deep true faith and to be very sensitive to social needs and problems, otherwise they cannot exercise and pursue successfully their science, which is a humanistic discipline; the queen of social sciences. Today, even scientists have lost the respect from the people.

The conclusion is that crises must be prevented, ${ }^{167}$ if it is possible, and not to be corrected and be reduced or to be diminished because their social cost, sometimes, is infinite, and definitely, the responsible creators must be punished. But, in a market oriented economy, which depends on imports (lack of self-sufficiency) this is impossible because the greedy agents try to satisfy their self-interest and not the social one. This self-interest creates different episodes, disturbances, disequilibria, uncertainties, exaggerations, arrogances, greed, fear, unethical business practices,

\footnotetext{
163 This Fed's anti-social "innovation" (ample reserves and paying interest of reserves) has kept the deposit rate closed to zero $\left(i_{D}=0.05 \%\right)$ for more than twelve years and because we are living in a free market economic system, banks charge an unethical (usurious) interest rate on credit cards of $39.99 \%$ and are paying another unethical rate of $0.05 \%$ on deposits (a spread of $39.94 \%$ ). Kallianiotis (2017a) suggests different optimal interest rates for our economy. See, https://www.valuepenguin.com/banking/average-bank-interest-rates

164 See, Business Cycles. https://en.wikipedia.org/wiki/Business_cycle

165 See, Keynesian Economics, https://en.wikipedia.org/wiki/Keynesian_economics

166 See, Neoclassical Economics, https://en.wikipedia.org/wiki/Neoclassical_economics

167 See, Kallianiotis (2020c).
} 
redistributions, inefficiencies, losses of wealth and income, unemployment and lately, fear (intimidation) and control, political crises and absurd wars (i.e., Afghanistan, etc.). Public policies (fiscal, trade, and the policy in question here, the monetary) are needed to reduce these problems, to smooth the business cycles and improve the social welfare of the citizens. This latest economic crisis was unique in our economic history, but it is the first of many others that we will see in the near future, like the suspicious current coronavirus (Chinese virus or Wuhan virus or COVID-19) ${ }^{168}$ one with its destructive health and economic effects. ${ }^{169}$ This is another "benefit" of the inhumane globalization. ${ }^{170}$ The central bank's policies must be more social than market oriented as they are now. This "independence" of the central banks around the world has caused serious problems to the nations' welfare. The world's problem, today, is that all these institutions and international organization are completely controlled. Then, nothing majestic or inspired is expected from these institutions or by the impotent U.N. What a pity and delusion for the world that had put its hope on them after WWII!

168 It started as a healthcare crisis $\Rightarrow>$ financial crisis $\Rightarrow>$ economic crisis $=>$ election irregularities $=>$ "domestic terrorism" => human control $=>$ depression $=>$ an anti-Trump tool $=>$ a questionable vaccine $=>$ a very suspicious crisis $=>$ unorthodox liberalism $=>$ climate issues $=>$ cancel culture $=>$ open borders $=>$ censorship by the big tech $=>$ critical race theory $\Rightarrow>$ students indoctrination $=>$ group thinking $=>$ loss of rights and liberty $=>$ China's aggressiveness $=>$ invasion of privacy $=>$ control over information $=>$ medical misinformation $\Rightarrow>$ vaccination mandate $=>$ vaccine passport $\Rightarrow>$ "human engineering" $=>$ Divine Justice $=>\sigma \varphi \rho \alpha ́ \gamma ı \sigma \mu \alpha$. The advanced nations must find out who has created this crisis and punish them. Governments cannot continue to cave in with the plans of the "economic elites" (dark powers). A group of senior lawmakers from eight democracies including the U.S. have launched a new cross-parliamentary alliance to help counter what they say is the threat China's growing influence poses to global trade, security and human rights.

https://www.bloomberg.com/news/articles/2020-06-05/lawmakers-in-eight-countries-form-newalliance-to-counter-china

169 The current coronavirus crisis is a pandemic worse than war. The country is scrambling for necessities because everything is coming from China. Health workers were facing shortages of vital equipment and drugs. This economic crisis will be unmeasurable; the growth of the GDP will be very low. (ABC News, March 18, 2020). The current crisis is actually a new U.S.-China cold war. This combined crisis (healthcare and economic) by the global elites will lead the world to a global depression and will terrorize all people, which is the only way for a global control through fear. See also, "COVID-19 Research Resources", Federal Reserve Bank of St. Luis, https://research.stlouisfed.org/resources/covid19/?utm_medium $=$ email\&utm_campaign $=202003 \mathrm{C} \% 20$ Research $\% 20$ Newsletter\&utm content $=20$ 2003C\%20Research\%20Newsletter+CID 807cd9d2ccb00431c4d1f718c446fec6\&utm_source=Re search\%20newsletter\&utm term=COVID-19\%20resources

${ }_{170}$ Globalization has caused serious problems to developed countries: (1) Destruction of domestic jobs (increase in unemployment), (2) National security problems, (3) The infant industry protection, (4) The unfair competition from low cost of production countries, (5) Illegal migration, (6) Dilution of indigenous cultures and values, (7) The destruction of the sovereign nation, (8) Contagion from virus coming from under-developing countries, (9) Increase of systemic risk, (10) A war against Christianity and Christians, (11) Re-writing history, (12) Ecumenism (common faith), (13) Global deception, (14) Global control, (15) Global submission of people, (16) Global preparation for the acceptance of the deceiver, (17) Censorship, (18) Reinstatement of the Malthusian Theory on population (reduction of population) and many other suspicious anti-humane means and practices. 
Finally, in the U.S. there was a big conflict and opposition from the Democratic Party against the Republican administration, which became worse during the latest Afghanistan crisis. ${ }^{171}$ This cultivated division by the "progressive" (liberal globalists) could cause serious problems in the country as it happened in the past in Europe. Then, our political crisis exceeds the health and economic crises. The fiscal stimulus ${ }^{172}$ benefited very little the economy to start a small recovery after the partial opening of businesses, but the national debt is becoming unbearable. Fed's chairman, Jerome Powell, was also in favor of a strong economic stimulus and he mentioned at the FOMC meeting on April 29, 2020 that the Fed will continue with a zero interest rate to support the economy. ${ }^{173}$ But, a zero target rate by the Fed and its new monetary policy cannot benefit the economy (its growth and employment); it creates new bubbles and inflation and discourages savings with the zero deposit rates. We hope, all these past mistakes to teach us one important lesson that "moderation in everything" and individuals and societies (nations) need an optimal tax, financial markets and institutions need regulations, politicians have to stop the division and the cancel culture of the country, and a value oriented system of selfsufficiency is important, which will maximize social welfare, confidence, freedoms, liberty, and will make our politico-economic system better. You cannot undermine the foundations of a nation and try to base it on lies and wrong philosophies. Then, the solution is "moderation, efficiency, tradition, pro-American policies, correct education, and perfection".

ACKNOWLEDGEMENTS. I would like to acknowledge the assistance provided by William F. Schwalm and Janice Mecadon. Financial support (professional travel expenses, submission fees, etc.) are provided by Provost's Office (Faculty Travel Funds, Henry George Fund, and Faculty Development Funds). The usual disclaimer applies. Then, all remaining errors are mine.

\footnotetext{
171 See, "Afghanistan-Taliban Crisis LIVE Updates: Future of Kabul airport subject of intense negotiations", https://www.moneycontrol.com/news/world/afghanistan-taliban-crisis-live-newsupdates-kabul-airport-attack-evacuation-panjshir-mullah-baradar-us-joe-biden-7399511.html

172 More than one million dead Americans were sent stimulus checks (and they voted for the November 3, 2020 elections), costing the federal government near \$1.4 billion in April 2020, a government watchdog reported on June 24, 2020. See,

https://dailycaller.com/2020/06/25/one-million-dead-americans-stimulus-checks-reportcoronavirus/. From the $2^{\text {nd }}$ stimulus package only $9 \%$ went for the relief from the COVID pandemic. (Fox News, 3/10/2021). See also, https://www.politifact.com/factchecks/2021/mar/01/scottfitzgerald/fitzgerald-overstates-claim-pork-covid-19-relief-b/

173 See, "Fed's Powell Says US Economy Will Need More Stimulus", https://news.yahoo.com/fed-powell-says-us-economy-223222543.html
} 


\section{References}

[1] Bank of Canada. (2017). "Monetary Policy".

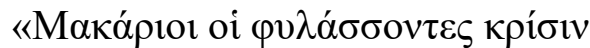

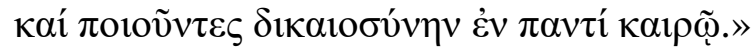
$\Psi \alpha \lambda \mu$ ó $\varsigma 105,3$ http://www.bankofcanada.ca/core-functions/monetary-policy/

[2] Bernanke, B. (2004). "The Great Moderation." Speech given at the annual meetings of the Eastern Economic Association, February 20, 2004. https://www.federalreserve.gov/boarddocs/speeches/2004/20040220/

[3] Bindseil, Ulrich. (2016). "Evaluating Monetary Policy Operational Frameworks," in Designing Resilient Monetary Policy Frameworks for the Future. Proceedings of the Federal Reserve Bank of Kansas City Jackson Hole Economic Policy Conference, Jackson Hole, WY, August 25-27, pp. 179-277. https://www.kansascityfed.org/publications/research/escp/symposiums/ /med ia/6c10f54077ef4f70ae9214d2ac5dad35.ashx

[4] Brown, E. (2019). "Why Is the Fed Paying So Much Interest to Banks?", April 1, 2019.

https://www.truthdig.com/articles/why-is-the-fed-paying-so-much-interest-to-banks/

[5] Bullard, J. (2018a). "What Is the Best Strategy for Extending the U.S.

Economy's Expansion?", Federal Reserve Bank of St. Louis, September 12, p. 1, https://www.stlouisfed.org/from-the-president/speeches-andpresentations/2018/what-is-best-strategy-extending-expansion

[6] Bullard, J. (2018b). "Allan Meltzer and the Search for a Nominal Anchor", Review, Federal Reserve Bank of St. Louis, Vol. 100, No, 2, Second Quarter, pp. 117-126.

https://research.stlouisfed.org/publications/review/2018/02/13/allan-meltzerand-the-search-for-a-nominal-anchor

[7] Bullard, J. (2017). "An Illustrative Calculation of $r$ †.” Federal Reserve Bank of Atlanta 22nd Annual Financial Markets Conference, Amelia Island, FL, May 8.

https://www.stlouisfed.org/ /media/Files/PDFs/Bullard/remarks/2017/Bullar d_Amelia_Island_8_May_2017.pdf?la=en.

[8] Caggese, A. and Perez-Orive, A. (2017). "Capital Misallocation and Secular Stagnation." Finance and Economics Discussion Series 2017-009, Board of Governors of the Federal Reserve System.

[9] Cochrane, J. H. (2001). Asset Pricing, Princeton University Press.

[10] Coibion, O. and Gorodnichenko, Y. (2011). "Monetary Policy, Trend Inflation, and the Great Moderation: An Alternative Interpretation", American Economic Review, 101, February, pp. 341-370

[11] Cooke, D. A. and Gavin, W. T. (2015). "Three Scenarios for Interest Rates in the Transition to Normalcy." Federal Reserve Bank of St. Louis Review, First Quarter, 97(1), pp. 1-24.

https://papers.ssrn.com/sol3/papers.cfm?abstract_id=2646132 
[12] DeLong, J. B. (1997). “America's Peacetime Inflation: The 1970s," in C. Romer and D.H. Romer (editors), Reducing Inflation:Motivation and Strategy. University of Chicago Press, pp. 247-80.

[13] D'Erasmo, P. (2018). "Are Higher Capital Requirements Worth It?", Economic Insights, Federal Reserve Bank of Philadelphia, Volume 3, Issue 2, Second Quarter, pp. 1-8.

[14] Engemann, K. (2019). “The Fed's Inflation Target: Why 2 Percent?”, Federal Reserve Bank of St. Louis, January 16, pp. 1-5. https://www.stlouisfed.org/open-vault/2019/january/fed-inflation-target-2percent

[15] Farla-e-Castro, M. (2019). "Can Countercyclical Capital Buffers Help Prevent a Financial Crisis?", ECONOMIC Synopses, pp. 1-2. https://files.stlouisfed.org/files/htdocs/publications/economicsynopses/2019/06/21/can-countercyclical-capital-buffers-help-prevent-afinancial-crisis.pdf

[16] Firestone, S. Lorenc, A. and Ranish, B. (2019). "An Empirical Economic Assessment of the Costs and Benefits of Bank Capital in the United States", Federal Reserve Bank of St. Louis, REVIEW, pp. 203-230. https://files.stlouisfed.org/files/htdocs/publications/review/2019/07/12/anempirical-economic-assessment-of-the-costs-and-benefits-of-bank-capital-inthe-united-states.pdf

[17] Fawley, B. W. and Neely, C. J. (2013). "Four Stories of Quantitative Easing", Federal Reserve Bank of St. Louis Review, January-February, 95(1), pp. 5188.

https://research.stlouisfed.org/publications/review/2013/01/04/four-storiesof-quantitative-easing/

[18] Foster, L., Grim, C. and Haltiwanger, J. (2016). "Reallocation in the Great Recession: Cleansing or Not?" in D. Card and A. Mas, organizers, Labor Markets in the Aftermath of the Great Recession. National Bureau of Economic Research, pp. 293-331.

[19] Gagnon, J. E. and Sack, B. (2014). Monetary Policy with Abundant Liquidity: A New Operating Framework for the Federal Reserve, Peterson Institute for International Economics.

[20] Gavin, W. T. (2018). "Monetary Policy Regimes and the Real Interest Rate", Review, Federal Reserve Bank of St. Louis, Vol. 100, No, 2, Second Quarter, pp. 151-169.

[21] Gavin, W. T., Keen, B. D., Richter, A. W. and Throckmorton, N. A. (2015). "The Zero Lower Bound, the Dual Mandate, and Unconventional Dynamics." Journal of Economic Dynamics \& Control, 55, pp. 14-38.

[22] Gavin, W. T. and Kydland, F. E. (2000). "The Nominal Facts and the October 1979 Policy Change." Federal Reserve Bank of St. Louis Review, 82(6), pp. 39-61. http://citeseerx.ist.psu.edu/viewdoc/summary?doi=10.1.1.196.4648 
[23] Gavin, W. T. and Kydland, F. E. (1999). "Endogenous Money Supply and the Business Cycle." Review of Economic Dynamics, 2(2), pp. 347-69. https://www.sciencedirect.com/science/article/pii/S1094202598900552

[24] Gomme, ., Ravikumar, B. and Rupert, P. (2015). "Secular Stagnation and Returns on Capital." Economic Synopses, No. 19, August 18. https://research.stlouisfed.org/publications/economicsynopses/2015/08/18/secular-stagnation-and-returns-on-capital/

[25] Gomme, P., Ravikumar, B. and Rupert, P. (2011). "The Return to Capital and the Business Cycle." Review of Economic Dynamics, 14(2), pp. 262-78. https://ac.els-cdn.com/S1094202510000591/1-s2.0-S1094202510000591main.pdf? tid=24378eb9-b6a0-4569-ba72346729689c8b\&acdnat $=1530286243 \quad 438 b 80$ cee525e117b3c07902e3b5b961

[26] Greenspan, A. (2004). "Risk and Uncertainty in Monetary Policy", American Economic Review, 94 (2), pp. 33-40.

[27] Hadjimichalakis, M. G. (1982). Monetary Policy and Modern Money Markets, U.S.A.: Lexington Books.

[28] Holston, K., Laubach, T. and Williams, J. C. (2016). "Measuring the Natural Rate of Interest: International Trends and Determinants." Working Paper 2016-11, Federal Reserve Bank of San Francisco, December. https://www.frbsf.org/economic-research/publications/workingpapers/2016/11/

[29] Ihrig, J., Peneva, E., and Wolla, S. A. (2021). "Inflation Expectations, the Phillips Curve, and the Fed's Dual Mandate", PAGE ONE Economics, Economic Research Federal Reserve Bank of St. Louis, Summer, pp. 1-8. https://research.stlouisfed.org/publications/page1-econ/2021/07/15/inflationexpectations-the-phillips-curve-and-the-feds-dualmandate?utm_medium $=$ email\&utm_campaign $=202108 \% 20$ Research $\% 20 \mathrm{Ne}$ wsletter\&utm_content=202108\%20Research\%20Newsletter+CID_921402a9 d24e9c41b5beabca068bd6cc\&utm_source=Research\%20newsletter\&utm_ter $\mathrm{m}=$ Page\%200ne\%20Economics\%20essay

[30] Ihrig, J. and Wolla, S. A. (2020). "The Fed's New Monetary Policy Tools", Page One Economics, Economic Research Federal Reserve Bank of St. Louis. https://research.stlouisfed.org/publications/page1-econ/2020/08/03/the-fedsnew-monetary-policy-tools

[31] Kallianiotis, I. N. (2021a). "Monetary Policy: Effectiveness, Efficiency, Risk, and Perspectives", International Journal of Social Sciences and Management Review, Volume 04, Issue 04, July-August 2021, pp. 46-95. http://ijssmr.org/uploads2021/ijssmr04_35.pdf and https://ijssmr.org/2021/07/22/monetary-policy-effectiveness-efficiency-riskand-perspectives/

[32] Kallianiotis, I. N. (2021b). "Ethics in Finance, Public Policies, and Institutions: The Latest Financial and Social Crises", International Journal of Managerial Studies and Research (IJMSR), Volume 9, Issue 1, pp. 13-41. https://arcjournals.org/international-journal-of-managerial-studies- 
and-research/volume-9-issue-1/,https://arcjournals.org/pdfs/ijmsr/v9i1/3.pdf, file:///C:/Users/R97719842/Downloads/02200133\%20(2).pdf

[33] Kallianiotis, I. N. (2021c). "The New Monetary Policy: Its Social Cost and Benefits", Chapter 1, in Progress in Economics Research, Volume 46, Albert Tavidze (Editor), pp. 1-111, Hauppauge, N.Y.: Nova Science Publishers, May 2021, ISBN: 978-1-53619-704-4 (eBook) and ISBN: 1549-1552. https://novapublishers.com/shop/progress-in-economics-research-volume-46/

[34] Kallianiotis, I. N. (2020a). "The Two Economic Crises of the 21st Century and the Substitution of Fiscal Policy by Monetary Policy", Chapter 1 in Progress in Economics Research. Volume 45, Albert Tavidze (Editor), pp. 1-91, Hauppauge, N.Y.: Nova Science Publishers, November, ISBN: 978-1-53618895 (eBook) and ISBN: 1549-1552

https://novapublishers.com/shop/progress-in-economics-research-volume-45/

[35] Kallianiotis, I. N. (2020b). "Exchange Rate Determination: The PortfolioBalance Approach", Journal of Applied Finance \& Banking, Vol. 11, Issue 1, October 13, 2020, pp. 19-40.

https://www.scienpress.com/journal_focus.asp?Main_Id=56 and https://www.scienpress.com/journal_focus.asp?main_id=56\&Sub_id=IV\&Iss $\underline{\text { ue }=1969967}$

[36] Kallianiotis, I. N. (2020c). "Can Monetary Policy Prevent Financial Crises?", International Journal of Economics and Financial Research, Volume 6, Number 4, April, pp. 51-75.

https://ideas.repec.org/s/arp/ijefrr.html and https://ideas.repec.org/a/arp/ijefrr/2020p51-75.html

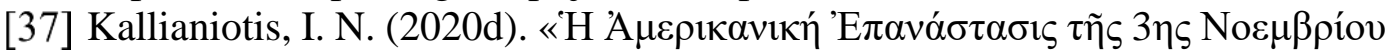

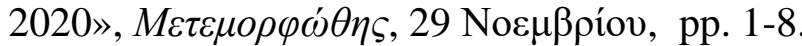
http://metemorfothis.blogspot.com/2020/11/3-2020.html

[38] Kallianiotis, I. N. (2019a). Foreign Exchange Rates and International Finance, Hauppauge, N.Y.: Nova Science Publishers, October, ISBN: 978-153616-550-0.

https://novapublishers.com/shop/foreign-exchange-rates-and-internationalfinance/

[39] Kallianiotis, I. N. (2019b). "Monetary Policy: Is the Dual Mandate of the Fed Maximizing the Social Welfare?" International Journal of Economics and Financial Research, Vol. 5, No. 6, June, pp. 112-142.

https://arpgweb.com/journal/5/archive/06-2019/6/5, https://arpgweb.com/pdf-files/ijefr5(6)112-142.pdf

[40] Kallianiotis, I. N. (2019c). "Monetary Policy, Real Cost of Capital, Financial Markets, and the Real Economic Growth", Journal of Applied Finance \& Banking, Vol. 9, No. 1, pp. 75-118.

http://www.scienpress.com/journal_focus.asp?main_id=56\&Sub_id=IV\&Issu $\underline{\mathrm{e}=810815}$

http://www.scienpress.com/Upload/JAFB/Vol\%209_1_4.pdf 
[41] Kallianiotis, I. N. (2018). The European Union and its Debt Crises: The Deception of the Greeks, New York: Nova Science Publishers, Inc.

[42] Kallianiotis, I. N. (2017a). "Central Banks, Monetary Policy, and their Efficiency”, (Chapter 1) in Monetary Policy: Perspectives, Strategies and Challenges, Harriet Ward (editor), New York: Nova Science Publishers.

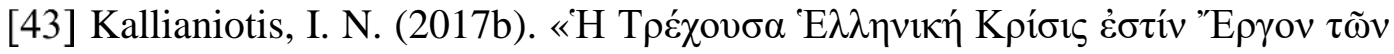

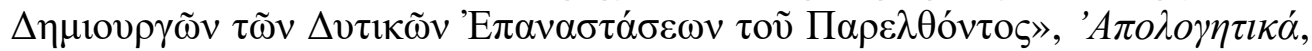
February 19, pp. 1-17. http://apologitikaa.blogspot.com.cy/2017/02/i.html

[44] Kallianiotis, I. N. (2015). “The Latest 'Planned' Financial Crisis, Which Caused the First Depression of the $21^{\text {st }}$ Century, Was a Moral and Political Crisis", in Global Financial Crisis: Causes, Consequences and Impact on Economic Growth, Jeanne Barnett (editor), New York: Nova Publishers, December, Chapter 2, pp. 15-78.

[45] Kallianiotis, I. N. (2013). Exchange Rates and International Financial Economics: History, Theories, and Practices, New York: Palgrave Macmillan.

[46] Kallianiotis, I. N. (2004). "Unemployment and Risk Revisited: The Dual Disease of our Socio-Economic System”, Journal of Business and Society, Vol. 17, No. 1 \& 2, pp. 46-66.

[47] Kallianiotis, I. N. and Petsas J. (2020). "The Effectiveness of the Single Mandate of the ECB and the Dual of the Fed", Journal of Applied Finance \& Banking, Vol. 10, Issue 4, May 1, pp. 115-169.

http://www.scienpress.com/journal_focus.asp?main_id=56\&Sub_id=IV\&voli $\underline{\mathrm{d}=442}$

http://www.scienpress.com/journal_focus.asp?main_id=56\&Sub_id=IV\&Issu e=1747583, http://www.scienpress.com/Upload/JAFB/Vol\%2010_4_11.pdf

[48] Komlos, J. (2019a). "The Real U.S. Unemployment Rate is Twice the Official Rate, and the Phillips Curve", https://www.dropbox.com/s/tooigw05ojqlxnv/real\%20unemployment\%20ne w.pdf?dl=0.

Also,https://drive.google.com/file/d/1913Um32spONxLlQgFgPz6VQxPtYt7 Ieb/view?usp=sharing

[49] Komlos, J. (2019b). Foundations of Real-World Economics, Second Edition, New York: Routledge.

[50] Lucas, R. (1976). "Econometric Policy Evaluation: A Critique", In Brunner, K. and Meltzer, A., The Phillips Curve and Labor Markets, CarnegieRochester Conference Series on Public Policy, 1, New York: American Elsevier, pp. 19-46.

[51] Mishkin, F. S. and Eakins, S. G. (2018). Financial Markets and Institutions, Ninth Edition, New York, N.Y.: Pearson.

[52] Nelson, E. (2005). "The Great Inflation of the Seventies: What Really Happened?" B.E. Journal of Macroeconomics: Advances in Macroeconomics, 5(1), pp. 1-48.

[53] Poole, W. and Wheelock, D. C. (2008). "Stable Prices, Stable Economy: Keeping Inflation in Check Must Be No. 1 Goal of Monetary Policymakers", 
Federal Reserve Bank of St. Louis, January 1.

https://www.stlouisfed.org/publications/regional-economist/january2008/stable-prices-stable-economy-keeping-inflation-in-check-must-be-no-1goal-of-monetary-policymakers

[54] Potter, S. (2017). "Implementing Monetary Policy with the Balance Sheet." Speech at the ECB workshop Money Markets, Monetary Policy Implementation, and Central Bank Balance Sheets, Frankfurt Am Main, Germany, November 6. https://www.bis.org/review/r171106f.pdf

[55] Ross, S. A., Westerfield, R. W., Jaffe, J. and Jordan, B. D. (2016). Corporate Finance, $11^{\text {th }}$ edition, New York, N.Y.: McGraw-Hill Education.

[56] Stiglitz, J. (2002). Globalization and its discontents, New York: W.W. Norton \& Company.

[57] Stock, J. H. and Watson, M. W. (2003). "Has the Business Cycle Changed and Why?" in M. Gertler and K. Rogoff (editors), NBER Macroeconomics Annual 2002. Volume 17. MIT Press.

[58] Summers, L. H. (2017). "Less is More When It Comes to Federal Reserve Policy." Financial Times, May 7. https://www.ft.com/content/ab77d236-318c11e7-9555-23ef563ecf9a

[59] Taylor, J. B. (2017). "Rules versus Discretion: Assessing the Debate over the Conduct of Monetary Policy", NBER Working Paper Series 24149, December, pp. 1-43. http://www.nber.org/papers/w24149

[60] Taylor, J. B. (2013). "Reviewing the 'Too Low for Too Long' Evidence." Economics One, October 19.

https://economicsone.com/2013/10/19/reviewing-the-too-low-for-too-longevidence/

[61] Taylor, J. B. (1993). "Discretion versus Policy Rules in Practice". CarnegieRochester Conference Series on Public Policy 39, pp. 195-214.

[62] Williams, J. C. (2014). "Monetary Policy at the Zero Lower Bound: Putting Theory into Practice." Hutchins Center on Fiscal \& Monetary Policy at Brookings, January 16.

https://www.brookings.edu/research/monetary-policy-at-the-zero-lowerbound-putting-theory-into-practice/f

[63] Williams, J. C. (2017). "The Global Growth Slump: Causes and Consequences." Federal Reserve Bank of San Francisco Economic Letter, 2017-19, July 3.

https://www.frbsf.org/economic-research/publications/economicletter/2017/july/global-growth-slump-causes-consequences-speech/

[64] Williamson, S. (2018). "Inflation Control: Do Central Bankers Have it Right?”, Review, Federal Reserve Bank of St. Louis, Vol. 100, No. 2, Second Quarter, pp. 127-150. https://research.stlouisfed.org/publications/review/2018/04/16/inflationcontrol-do-central-bankers-have-it-right/ 
[65] Williamson, S. D. (2016a). "Neo-Fisherism: A Radical Idea, or the Most Obvious Solution to the Low-Inflation Problem?", Regional Economist, Federal Reserve Bank of St. Louis, July. https://www.stlouisfed.org/publications/regional-economist/july-2016/neofisherism-a-radical-idea-or-the-most-obvious-solution-to-the-low-inflationproblem

[66] Williamson, S. D. (2016b). "Neo-Fisherian Denial." New Monetarist (blog), April 14. http://newmonetarism.blogspot.com/

[67] Williamson, S. D. (2014). "Monetary Policy in the United States: A Brave New World?", Federal Reserve Bank of St. Louis Review, Second Quarter, 96(2), pp. 111-21.

https://files.stlouisfed.org/files/htdocs/publications/review/2014/q2/williamso n.pdf

[68] Williamson, S. D. (2012). "Liquidity, Monetary Policy, and the Financial Crisis: A New Monetarist Approach", American Economic Review, 102(6), pp. 2570-605.

https://pubs.aeaweb.org/doi/pdfplus/10.1257/aer.102.6.2570

[69] Woodford, M. (2003). Interest and Prices: Foundations of a Theory of Monetary Policy, Princeton, N.J.: Princeton University Press.

[70] Yellen, J. (2017). "The Goals of Monetary Policy and How We Pursue Them". Speech at the Commonwealth Club, San Francisco, CA. https://www.federalreserve.gov/newsevents/speech/yellen20170118a.htm 


\section{APPENDIX}

Table A1: Correlation and Causality Tests between the monetary policy tools $\left(i_{F F_{t}}^{e f f}, m b_{t}\right.$, and $\left.m_{t}\right)$ and the objective variables $\left(d j i a_{t}, r g d p_{t}, i_{10 Y T B_{t}}, p_{t}\right.$, and $\left.u_{t}\right)$.

(1) Zero Interest Rate Regime (2008:12-2015:11):

$$
\begin{aligned}
& \rho_{i_{F F}, d j i a}=-0.592 \quad i_{F F} \Rightarrow \neq d j i a \quad \text { and } d j i a \Rightarrow i_{F F}\left(F=4.678^{* *}\right) \\
& \rho_{i_{F F}, r g d p}=-0.489 \quad i_{F F} \Rightarrow \neq r g d p \text { and } r g d p \Rightarrow \neq i_{F F} \\
& \rho_{i_{F F}, i_{10 Y B}}=+0.224 \quad i_{F F} \Rightarrow i_{10 Y T B}\left(F=5.055^{* * * *} \text { and } i_{10 Y T B} \Rightarrow \neq i_{F F}\right. \\
& \rho_{i_{F F}, p}=-0.614 \quad i_{F F} \Rightarrow \neq p \text { and } p \Rightarrow i_{F F}\left(F=4.743^{* *}\right) \\
& \rho_{i_{F F}, u}=+0.425 \quad i_{F F} \Rightarrow u\left(F=4.468^{* * *}\right) \text { and } u \Rightarrow i_{F F}\left(F=2.522^{*}\right) \\
& \rho_{m b, d j i a}=+0.963 \quad m b \Rightarrow \operatorname{djia}\left(F=2.936^{*}\right) \quad \text { and } \operatorname{dji} a \Rightarrow m b\left(F=3.148^{* *}\right) \\
& \rho_{m b, r g d p}=+0.960 \quad m b \Rightarrow \operatorname{rgd}\left(F=4.259^{* *}\right) \text { and } r g d p \Rightarrow \neq m b \\
& \rho_{m b, i_{10 Y T B}}=-0.507 \quad m b \Rightarrow \neq i_{10 Y T B} \text { and } i_{10 Y T B} \Rightarrow \neq m b \\
& \rho_{m b, p}=+0.973 \quad m b \Rightarrow \neq p \text { and } p \Rightarrow m b\left(F=4.617^{* * *}\right) \\
& \rho_{m b, u}=-0.874 \quad m b \Rightarrow u\left(F=21.586^{* * * *} \text { and } u \Rightarrow \neq m b\right. \\
& \rho_{m, d j a}=+0.943 \quad m \Rightarrow \operatorname{dji} a\left(F=4.033^{* *}\right) \quad \text { and } \operatorname{djia} \Rightarrow m\left(F=4.618^{* * *}\right) \\
& \rho_{m, r g d p}=+0.984 \quad m \Rightarrow \operatorname{rgdp}\left(F=5.034^{* * * *}\right) \text { and } \operatorname{rgd} \Rightarrow \Rightarrow \neq m \\
& \rho_{m, i_{10 Y B}}=-0.613 \quad m \Rightarrow \neq i_{10 Y T B} \text { and } i_{10 Y T B} \Rightarrow \neq m \\
& \rho_{m, p}=+0.971 \quad m \Rightarrow \neq p \text { and } p \Rightarrow m\left(F=8.994^{* * * *}\right) \\
& \rho_{m, u}=-0.926 \quad m \Rightarrow u\left(F=24.116^{* * * *} \text { and } u \Rightarrow \neq m\right.
\end{aligned}
$$

(2) New Regime (2015:12-2020:12):

$$
\begin{array}{ll}
\rho_{i_{F F}, d j i a}=+0.409 & i_{F F} \Rightarrow \neq d j i a \quad \text { and } d j i a \Rightarrow i_{F F}\left(F=2.930^{*}\right) \\
\rho_{i_{F F}, r g d p}=+0.731 & i_{F F} \Rightarrow \operatorname{rgdp}\left(F=18.122^{* * * *}\right) \quad \text { and } \quad \operatorname{rgdp} \Rightarrow i_{F F}\left(F=2.738^{*}\right) \\
\rho_{i_{F F}, i_{10 Y B B}}=+0.661 & i_{F F} \Rightarrow \neq i_{10 Y T B} \quad \text { and } i_{10 Y T B} \Rightarrow i_{F F}\left(F=9.699^{* * * *}\right) \\
\rho_{i_{F F}, p}=+0.320 & i_{F F} \Rightarrow p\left(F=2.929^{*}\right) \text { and } p \Rightarrow \neq i_{F F}
\end{array}
$$




$$
\begin{aligned}
& \rho_{i_{F F}, u}=-0.623 \quad i_{F F} \Rightarrow u\left(F=48.585^{* * * *} \text { and } u \Rightarrow \neq i_{F F}\right. \\
& \rho_{m b, d j i a}=+0.129 \quad m b \Rightarrow \neq d j i a \quad \text { and djia } \Rightarrow \neq m b \\
& \rho_{m b, r g d p}=-0.439 \quad m b \Rightarrow r g d p\left(F=24.772^{* * * *}\right) \text { and } \quad r g d p \Rightarrow m b\left(F=8.321^{* * * *}\right) \\
& \rho_{m b, i_{10 Y I B}}=-0.649 \quad m b \Rightarrow \neq i_{10 Y T B} \text { and } i_{10 Y T B} \Rightarrow m b\left(F=6.059^{* * * *}\right) \\
& \rho_{m b, p}=+0.146 \quad m b \Rightarrow \neq p \quad \text { and } p \Rightarrow \neq m b \\
& \rho_{m b, u}=+0.804 \quad m b \Rightarrow u\left(F=11.177^{* * *} \text { and } u \Rightarrow \neq m b\right. \\
& \rho_{m, d j i a}=+0.777 \quad m \Rightarrow \neq d j i a \quad \text { and } d j i a \Rightarrow \neq m \\
& \rho_{m, r g d p}=+0.357 \quad m \Rightarrow r g d p\left(F=5.034^{* * * *}\right) \text { and } \quad r g d p \Rightarrow \neq m \\
& \rho_{m, i_{10 Y I B}}=-0.640 \quad m \Rightarrow \neq i_{10 Y T B} \text { and } i_{10 Y T B} \Rightarrow m\left(F=4.495^{* *}\right) \\
& \rho_{m, p}=+0.871 \quad m \Rightarrow \neq p \text { and } p \Rightarrow m\left(F=5.208^{* * *}\right) \\
& \rho_{m, u}=+0.583 \quad m \Rightarrow u\left(F=14.945^{* * *} \text { and } u \Rightarrow m\left(F=4.330^{* *}\right)\right.
\end{aligned}
$$

Note: $\rho_{i_{F F}, d j i a}=$ correlation coefficients between $i_{F F}$ and djia, $m b \Rightarrow u(F)=$ causality test between $m b$ and $u$ ( $m b$ causes $u$ and F-statistic in parenthesis), $u \Rightarrow \neq m b=$ no causality between $u$ and $m b$. $d j i a_{t}=\ln$ of U.S. Dow Jones Industrial Average Index, $r g d p_{t}=\ln$ of U.S. real GDP, $i_{10 Y T B_{t}}=$ U.S 10-Year Treasury Bonds Rate, $p_{t}=\ln$ of U.S. CPI, $u_{t}=$ U.S. unemployment rate, $c_{0}=$ constant term, $i_{F F_{t}}^{e f f}=$ U.S. effective federal funds rate, $m b_{t}=\ln$ of U.S. monetary base, $m_{t}=\ln$ of U.S. money supply (M2), ${ }^{* * *}=$ significant at the $1 \%$ level, ${ }^{* *}=$ significant at the $5 \%$ level, ${ }^{*}=$ significant at the $10 \%$ level, Source: Economagic.com and Yahoo/Finance. . 
Table A2: Measuring the correlation $(\rho)$ and testing the causality $(\Rightarrow)$ between the instruments $\left(i_{F F_{t}}, M B\right.$, and $\left.M^{s}\right)$ and the objective variables $\left(C, I, T A, e\right.$, and $\left.r g d p_{t}\right)$

(1) ZIRR (2008:12-2015:11):

$$
\begin{aligned}
& \rho_{i_{F F}, c}=-0.535 \quad i_{F F} \Rightarrow c\left(F=7.656^{* * * *}\right) \quad \text { and } c \Rightarrow i_{F F}\left(F=3.724^{* *}\right) \\
& \rho_{i_{F F}, i}=-0.471 \quad i_{F F} \Rightarrow \neq i \text { and } i \Rightarrow \neq i_{F F} \\
& \rho_{i_{F F}, t a}=-0.358 \quad i_{F F} \Rightarrow \neq t a \text { and } t a \Rightarrow i_{F F}\left(F=6.068^{* * * *}\right) \\
& \rho_{i_{F F}, e}=-0.073 \quad i_{F F} \Rightarrow e\left(F=2.877^{*}\right) \text { and } e \Rightarrow \neq i_{F F} \\
& \rho_{i_{F F}, r g d p}=-0.489 \quad i_{F F} \Rightarrow \neq r g d p \text { and } \quad r g d p \Rightarrow \neq i_{F F} \\
& \rho_{m b, c}=+0.974 \quad m b \Rightarrow c\left(F=5.126^{* * * *}\right) \quad \text { and } c \Rightarrow m b\left(F=2.981^{*}\right) \\
& \rho_{m b, i}=+0.919 \quad m b \Rightarrow i\left(F=4.962^{* * * *}\right) \text { and } i \Rightarrow m b\left(F=2.445^{*}\right) \\
& \rho_{m b, t a}=+0.663 \quad m b \Rightarrow t a\left(F=2.726^{*}\right) \text { and } t a \Rightarrow m b\left(F=3.747^{* *}\right) \\
& \rho_{m b, e}=-0.501 \quad m b \Rightarrow e\left(F=4.433^{* *}\right) \text { and } e \Rightarrow \neq m b \\
& \rho_{m b, r g d p}=+0.960 \quad m b \Rightarrow r g d p\left(F=4.259^{* *}\right) \text { and } \operatorname{rgdp} \Rightarrow \neq m b \\
& \rho_{m, c}=+0.989 \quad m \Rightarrow \neq c \quad \text { and } c \Rightarrow m\left(F=8.757^{* * *}\right) \\
& \rho_{m, i}=+0.968 \quad m \Rightarrow i\left(F=6.478^{* * * *}\right) \text { and } i \Rightarrow \neq m \\
& \rho_{m, t a}=+0.697 \quad m \Rightarrow \operatorname{ta}\left(F=3.371^{* * *}\right) \text { and } \operatorname{ta} \Rightarrow m\left(F=4.519^{* * *}\right) \\
& \rho_{m, e}=-0.625 \quad m \Rightarrow e\left(F=3.416^{* *}\right) \text { and } e \Rightarrow \neq m \\
& \rho_{m, r g d p}=+0.984 \quad m \Rightarrow \operatorname{rgdp}\left(F=5.034^{\text {**** }} \text { and } r g d p \Rightarrow \neq m\right.
\end{aligned}
$$

(2) NR (2015:12-2020:12):

$$
\begin{array}{ll}
\rho_{i_{F F}, c}=+0.584 & i_{F F} \Rightarrow \neq c \quad \text { and } \quad c \Rightarrow i_{F F}\left(F=2.732^{*}\right) \\
\rho_{i_{F F}, i}=+0.502 & i_{F F} \Rightarrow i\left(F=21.519^{* * * *}\right) \text { and } i \Rightarrow \neq i_{F F} \\
\rho_{i_{F F}, t a}=+0.111 & i_{F F} \Rightarrow t a\left(F=6.286^{* * * *}\right) \text { and } t a \Rightarrow \neq i_{F F} \\
\rho_{i_{F F}, e}=+0.139 & i_{F F} \Rightarrow \neq e \quad \text { and } e \Rightarrow \neq i_{F F}
\end{array}
$$




$$
\begin{aligned}
& \rho_{i_{F F}, r g d p}=+0.731 \quad i_{F F} \Rightarrow r g d p\left(F=18.122^{* * *}\right) \text { and } \operatorname{rgdp} \Rightarrow i_{F F}\left(F=2.738^{*}\right) \\
& \rho_{m b, c}=-0.209 \quad m b \Rightarrow \neq c \quad \text { and } \quad c \Rightarrow m b\left(F=6.583^{* * *}\right) \\
& \rho_{m b, i}=-0.031 \quad m b \Rightarrow i\left(F=27.395^{* * *}\right) \text { and } i \Rightarrow m b\left(F=8.465^{* * *}\right) \\
& \rho_{m b, t a}=-0.279 \quad m b \Rightarrow \neq t a \quad \text { and } t a \Rightarrow \neq m b \\
& \rho_{m b, e}=+0.297 \quad m b \Rightarrow e\left(F=5.393^{* * *}\right) \text { and } e \Rightarrow \neq m b \\
& \rho_{m b, r g d p}=-0.439 \quad m b \Rightarrow r g d p\left(F=24.772^{* * *}\right) \quad \text { and } \quad r g d p \Rightarrow m b\left(F=8.321^{* * *}\right) \\
& \rho_{m, c}=+0.594 \quad m \Rightarrow c\left(F=2.911^{*}\right) \quad \text { and } c \Rightarrow m\left(F=10.133^{* * *}\right) \\
& \rho_{m, i}=+0.738 \quad m \Rightarrow i\left(F=16.826^{* * *}\right) \text { and } i \Rightarrow \neq m \\
& \rho_{m, t a}=-0.314 \quad m \Rightarrow t a\left(F=8.792^{* * * *}\right) \text { and } t a \Rightarrow m\left(F=3.180^{* *}\right) \\
& \rho_{m, e}=+0.281 \quad m \Rightarrow \neq e \quad \text { and } \quad e \Rightarrow \neq m \\
& \rho_{m, r g d p}=+0.357 \quad m \Rightarrow \operatorname{rgdp}\left(F=15.633^{* * *}\right) \text { and } \quad r g d p \Rightarrow \neq m
\end{aligned}
$$

Note: $\rho_{m, c}=$ correlation coefficients between $m$ and $\left.c, m b \Rightarrow e(F)\right)=$ causality test between $m b$ and $e$ ( $m b$ causes $e$ and F-statistic in parenthesis), $m b \Rightarrow \neq t a$ = no causality between $m b$ and $t a$.

Source: See, Table A1. 